\title{
Geomicrobiology of Nitrogen in a Coastal Aquifer: Isotopic and Molecular Methods to Examine Nitrification and Denitrification in Groundwater.
}

\author{
By \\ Daniel Richard Rogers \\ B.S., University of Connecticut, 1998 \\ M.S., University of Connecticut, 2001 \\ Submitted in partial fulfillment of the requirements for the degree of \\ Doctor of Philosophy \\ At the \\ MASSACHUSETTS INSTITUTE OF TECHNOLOGY \\ And the \\ WOODS HOLE OCEANOGRAPHIC INSTITUTION
}

June 2010

(C) 2010 Daniel Rogers. All rights reserved.

The author hereby grants to MIT and WHOI permission to reproduce and to distribute publicly paper and electronic copies of this thesis document in whole or in part in any medium now known or hereafter created.

Signature of Author

Joint Program in Oceanography/Applied Ocean Science and Engineering Massachusetts Institute of Technology and Woods Hole Oceanographic Institution

April 30, 2010

Certified by

Dr. Karen Casciotti

Thesis Supervisor

Accepted by

Dr. Roger Summons

Chair, Joint Committee for Chemical Oceanography

Massachusetts Institute of Technology/

Woods Hole Oceanographic Institution 


\title{
Geomicrobiology of Nitrogen in a Coastal Aquifer: Isotopic and Molecular Methods to Examine Nitrification and Denitrification in Groundwater.
}

By

Daniel Richard Rogers

\author{
Submitted to the Department of Marine Chemistry and Geochemistry, \\ Massachusetts Institute of Technology- Woods Hole Oceanographic Institution \\ Joint Program in Chemical Oceanography \\ In partial fulfillment of the requirements for the degree of \\ Doctor of Philosophy
}

\begin{abstract}
Excess nitrogen input is deleterious to coastal waters, resulting in deterioration of the water quality, increases in harmful algal blooms and disease in commercial fish stocks. A significant portion of this nitrogen enters coastal waters through groundwater systems. Here we use isotopic and molecular biological methods to identify the populations of nitrifiers and denitrifiers, where they occur, and what levels of activity are present through the upper four meters of a coastal groundwater system. This work shows two different populations of putative ammonia-oxidizing archaea (AOA) based on the ammonia monooxygenase gene ( $a m o A)$, one shallow population most closely related to open ocean water column-like sequences and a deeper population that is more closely related to estuarine-like AOA. Interestingly, while the surface population has a potential nitrification rates (456 $\mathrm{pmol} \mathrm{g}^{-1}$ sediment day ${ }^{-1}$ ) similar to marine sediments, the deeper population does not show detectable evidence of nitrification. Between these two archaeal populations resides an active population of ammonia-oxidizing bacteria with similar nitrification rates as the surface AOA population. The upper meter of the aquifer is also an active area of denitrification as evidenced by the coincident drop in nitrate concentration and increase in both $\delta^{15} \mathrm{~N}$ (up to $+20.1 \%$ ) and $\delta^{18} \mathrm{O}$ (up to $+11.7 \%$ ), characteristic of groundwater affected by denitrification. 16S rRNA gene surveys of the organisms present in the upper meter also are similar to soil/sediment type environments including many potential denitrifiers. However, nitrite reductase, nirS and nirK, genes were also recovered from the sediments with nirK dominating in the surface sediments. This contrasts with the deep salt wedge, where the microbial community $16 \mathrm{~S}$ rRNA genes appear more closely related to marine or reducing sediment/wastewater type organisms, and nirS genes become the dominant denitrification gene.
\end{abstract}

Thesis Supervisor: Dr. Karen Casciotti

Title: Associate Scientist, Woods Hole Oceanographic Institution 


\section{Acknowledgements}

I would like to thank the many people who helped me accomplish this work. First I would like to thank my advisor, Karen Casciotti. Karen has always been very supportive professionally and personally. Karen eagerly brought me into her lab and set me free to find my own research path which was only tangentially related to her own research goals. For Karen, this was courageous endeavor indeed. I have learned a lot during my time in the lab from Karen and other lab members. Matt McIlvin, Erin Banning, Carly Buchwald, Caitlin Frame, Alyson Santoro and Ed Leadbetter have all provided, expertise, counsel, insight and friendship.

My committee provided counsel and a labor force for the fieldwork detailed in the following pages. Matt Charette provided the able hands of Paul Henderson and Meagan Gonneea as well as ample instrument time and lab resources. Kevin Kroeger donated Laura Erban and Sandy Baldwin to the field experience and an office chair to many hours of discussion around groundwater geochemistry. Ed DeLong was instrumental in much of the molecular work presented here and I am indebted to him for the chance to try and address some very risky scientific questions.

During my time at WHOI, both as a student and as a technician, many wonderful scientists and people have mentored me. In particular, Meg Tivey and Wolfgang Bach took me under their collective arms to teach me everything I know about deep-sea geology and geochemistry. This has made me an infinitely better microbiologist. John Waterbury opened his lab up to me the moment I stepped foot on campus, initiating my into the realm of WHOI marine microbiology all the while teaching and entertaining me with stories of how the landmark studies really came about. Meg and John also always managed to turn any conversation away from science and back to life. Both have been excellent examples of how to balance science and family. This is the most important lesson I will take from them.

Of course, I am also indebted to my friends, though they still do not understand what it is I actually do for a living. Ron Welch, Paul Morrisey and Joe Giampietro have been like brothers to me. They have encouraged, taught, counseled, mourned and rejoiced with me. Thank you gentlemen, I love you all.

Finally I would like to thank my family. Mom, Dad and Kara thank you for keeping me grounded. Tonna-Marie, thank you for lifting my wings. Tonna-Marie, I really could not be the professional I am, or the man I am without your unwavering love and support. I love you.

Funding for the following work was generously provided by the National Science Foundation (KLC, OCE-0526277 and MAC, OCE-0524994), the Woods Hole Oceanographic Institution's Coastal Ocean Institute (KLC and DRR, 32031013), Ocean Venture Fund (DRR), Coastal Ocean Institute fellowship (DRR), and the Academic Programs Office of the MIT/WHOI Joint Program in Oceanography/Applied Ocean Science and Engineering. 


\section{Dedicated to my noble wife, Tonna-Marie. Her love and support is immeasurable.}

\section{Proverbs 31:10-31}

Who can find a wife of noble character? For her value is far more than rubies. The heart of her husband has confidence in her, and he has no lack of gain. She brings him good and not evil all the days of her life. She obtains wool and flax, and she is pleased to work with her hands. She is like the merchant ships; she brings her food from afar. She also gets up while it is still night, and provides food for her household and a portion to her female servants. She considers a field and buys it; from her own income she plants a vineyard. She begins her work vigorously, and she strengthens her arms. She knows that her merchandise is good, and her lamp does not go out in the night. Her hands take hold of the distaff, and her hands grasp the spindle. She extends her hand to the poor, and reaches out her hand to the needy. She is not afraid of the snow for her household, for all of her household are clothed with scarlet. She makes for herself coverlets; her clothing is fine linen and purple. Her husband is well-known in the city gate when he sits with the elders of the land. She makes linen garments and sells them, and supplies the merchants with sashes. She is clothed with strength and honor, and she can laugh at the time to come. She opens her mouth with wisdom, and loving instruction is on her tongue. She watches over the ways of her household, and does not eat the bread of idleness. Her children rise up and call her blessed, her husband also praises her: "Many daughters have done valiantly, but you surpass them all!" Charm is deceitful and beauty is fleeting, but a woman who fears the LORD will be praised. Give her credit for what she has accomplished, and let her works praise her in the city gates. 


\section{Table of Contents}

Abstract 3

Acknowledgements $\quad 5$

Chapter 1: Microbial communities in a coastal groundwater aquifer and their role in the nitrogen transformations. Introduction 14

Nitrification, Denitrification and Anaerobic Ammonia Oxidation: 19

Why Archaea may be important $\quad 22$

Research Approach $\quad 25$

References $\quad 30$

Chapter 2: Abundance and diversity of archaeal ammonia-oxidizers in a coastal $\begin{array}{ll}\text { groundwater aquifer. } & \mathbf{3 7}\end{array}$

Introduction $\quad 39$

Materials and Methods $\quad 40$

Study Area and Sample Collection $\quad 40$

Pore water and Sediment Sampling $\quad 41$

DNA Extraction $\quad 42$

Quantitative PCR $\quad 42$

Archaeal amoA Primer Screening $\quad 43$

PCR, Cloning and Sequencing $\quad 43$

Sequence analysis $\quad 44$

Results $\quad 45$

Environment Context $\quad 45$

16S rRNA gene abundance $\quad 45$

$\begin{array}{ll}\text { Archaeal amoA gene distributions } & 47\end{array}$

$\begin{array}{ll}\text { Bacterial amoA gene distribution } & 48\end{array}$

Archaeal 16S rRNA gene diversity 49

Archaeal amoA Clone Libraries $\quad 50$

Discussion $\quad 50$

16S rRNA gene abundance $\quad 51$

Archaeal 16S rRNA gene libraries $\quad 53$

Archaeal amoA Gene Libraries 53

Primer Sensitivity in amoA qPCR 55

Relative abundances of AOB and AOA 56

$\begin{array}{ll}\text { Conclusions } & 58\end{array}$

References $\quad 68$

Chapter 3: Isotopic and molecular evidence for denitrification in an $\begin{array}{ll}\text { anthropogeneically altered coastal aquifer. } & \mathbf{7 3}\end{array}$

$\begin{array}{ll}\text { Abstract } & 74\end{array}$

$\begin{array}{ll}\text { Introduction } & 75\end{array}$

$\begin{array}{ll}\text { Methods } & 77\end{array}$ 
$\begin{array}{ll}\text { Sample Collection } & 77\end{array}$

$\begin{array}{ll}\text { Nutrient concentration and isotopic analyses } & 78\end{array}$

$\begin{array}{ll}\text { DNA extraction } & 79\end{array}$

$\begin{array}{ll}\text { Quantitative PCR } & 79\end{array}$

PCR, Cloning and Sequencing $\quad 80$

Sequence analysis $\quad 81$

Results $\quad 82$

Nutrient Chemistry $\quad 82$

Nitrite reductase abundance and distribution $\quad 84$

Bacterial 16S rRNA Gene Diversity $\quad 84$

Discussion $\quad 87$

Isotopic evidence for denitrification $\quad 88$

Molecular evidence for denitrification $\quad 92$

The upper meter $\quad 93$

The Freshwater Plume $\quad 94$

Deep Salt Wedge Transition $\quad 95$

$\begin{array}{lr}\text { Implications } & 97\end{array}$

References 109

Chapter 4: Nitrification in a Coastal Groundwater Aquifer: Roles for both Archaea and

Bacteria in a Nitrogen Rich Sediment Column.

Abstract 116

Introduction 117

Methods 119

Sample Collection $\quad 119$

Nutrient measurement 120

${ }^{15} \mathrm{~N}$-Ammonium Tracer Experiment 120

Isotopic Analysis $\quad 121$

Rate Calculations $\quad 122$

Molecular Techniques $\quad 124$

Results $\quad 126$

Field Chemistry 126

${ }^{15} \mathrm{~N}$-Ammonium Incubations 126

Gene Expression 128

Discussion 131

Surface Meter 132

Fresh Groundwater Plume 133

Deep Salt Wedge 135

$\begin{array}{ll}\text { Conclusions } & 136\end{array}$

References $\quad 142$

Chapter 5: Waquoit Bay: Looking back through the sands and looking forward. 145

Introduction 146

The Bay Proper 148

Groundwater Hydrology 150

Surface Salt Zone $\quad 151$

Freshwater Plume $\quad 155$

Deep Salt wedge 156 
What about Anammox?

Implications

Future Directions

160

References

163 
Chapter 1: Microbial communities in a coastal groundwater aquifer and their role in the nitrogen transformations.

Daniel Rogers and Karen Casciotti

Department of Marine Chemistry and Geochemistry and ${ }^{\star}$ MIT/WHOI Joint Program in Chemical Oceanography, Woods Hole Oceanographic Institution, Woods Hole MA 02543. 


\section{Introduction}

Anthropogenic nitrogen, largely in the form of nitrate $\left(\mathrm{NO}_{3}{ }^{-}\right)$, is a deleterious pollutant in coastal ecosystems. Excess nitrogen addition to coastal waters, known as eutrophication, has broad deleterious effects on coastal ecosystems including increased hypoxia and anoxia, altered food webs and degraded sea grass beds, kelp beds and coral

reefs. These impacts result in decreased biodiversity, increased frequency and duration of harmful algal blooms, and compromised finfish and shellfish populations (Valiela et al. 1990; Valiela et al. 1992; Howarth et al. 2002). Three decades after the Clean Water Act (1972), the nitrogen flux into coastal waters has increased four to five-fold and as much as ten-fold in some areas as a result of human activity (Howarth et al. 2002). Despite efforts to lower aquatic nitrogen $(\mathrm{N})$ loading, two thirds of coastal waterways are moderately to severely impacted by nutrient pollution (Bricker et al. 1999; EPA 2001). With rapid population growth projected, mainly concentrated within 50 miles of the coastline, we can only expect N-loading in coastal systems to increase. To better understand the processes that may affect the eutrophication of coastal waters we must understand both the route of input and the processes that may remove nitrogen in transit to the coastal ocean. The work presented in this dissertation examines, in a coastal groundwater aquifer, (1) the balance of nitrification and denitrification, (2) which organism are involved in N-cycling at various depths and (3) what are the potential rates of nitrogen transformation by these communities.

It has long been known that much of the terrestrially derived nitrogen is transported to the coastal ocean through runoff and riverine inputs. However, submarine 
groundwater discharge (SGD), defined as any and all water flowing from the seabed to the continental margin regardless of composition, has been recognized as a mechanism to transport freshwater into coastal waters (Figure 1) (Moore 1999; Burnett et al. 2003; Moore 2006). While rivers amount to a point source of constituents to the coastal ocean, and thus are more amenable to investigation, SGD could be viewed as a spatially broad signal entering the coastal ocean. Due to the large spatial and temporal variability as well the remote and difficult to sample nature of the groundwater/sediment matrix, the role of SGD in coastal biogeochemistry has been understudied and underappreciated. Despite the inherent difficulties three general methods have been used to quantify the contribution of SGD to both the water and solutes to coastal waters. The first method of study entails the physical measurements of discharge rates using seepage meters or flow meters, resulting in a calculation of the local water flux from SGD (Bugna et al. 1996; Michael et al. 2003; Sholkovitz et al. 2003; Swarzenski et al. 2004). As a second approach, discharge rates can be estimated using tracer techniques usually involving the tracking of radium or radon isotopes (Moore 1996; Charette et al. 2001; Moore et al. 2008) or artificially injecting compounds such as sulfur hexafluoride (Cable and Martin 2008) or bromide (Hall et al. 1991) into the aquifer and quantifying the flux rate of the tracer to the coastal ocean. Finally, discharge rates can be estimated using various modeling approaches that are usually based on the mass balance of water and the assumption of steady state have been used to estimate groundwater flux into coastal waters (Thompson et al. 2007; Spiteri et al. 2008). Estimates of SGD suggest that it can be a significant contribution of water and chemical constituents into the coastal ocean, with water fluxes (freshwater and 
saltwater recirculation) as high as $40 \%$ of riverine and runoff inputs (Moore 1996). Freshwater discharge constitutes 6-10\% (Burnett et al. 2003) of the total discharge, roughly 3000-4000 $\mathrm{km}^{3} \mathrm{yr}^{-1}$ (Zektser and Loaiciga 1993).

The water flux of SGD into coastal water does not portray the full impact this process. While the global net flux of water from SGD is relatively small when compared to river inputs on the estuary scale the contribution of groundwater to the water flux can vary widely. However, water flux alone is not the only impact on the receiving waters, the composition of the water must also be considered. The solute load of SGD can differ greatly from the solute load delivered by river transport. It is important to realize that SGD is not just average river water percolating through an inert system of permeable rock and debris and finally empting into the coastal ocean as an underground river. The transit through the permeable rock, and the chemical and biological reactions occurring within the strata, alter the composition of the effluent water. Studies examining the leaching of elements and compounds from the rock and the ultimate transport to the coastal ocean are rare, and the data available is skewed because of the homogeneity of the rock type studied (mostly limestone or other Karst bedrocks as opposed to shale or other native rocks), however, the results are enlightening. Calcium, for example, is a major constituent of seawater present at a steady state concentration of $10 \mathrm{mM}$. In order to maintain this steady state concentration given the calculated inputs of calcium to the oceans, groundwater supply of calcium to the ocean must be $20 \%$ larger than the largest known source of the calcium to the ocean, river inputs (Milliman 1993). 
Calcium is not the only element or compound that may be supplied to or removed from saline groundwater through SGD and this exchange is determined by the rock involved and the chemical environment at the location of groundwater/seawater mixing analogous to the particle transport and flocculation in estuaries. Moore (1999) called this area of mixing fresh groundwater and seawater the subterranean estuary (STE). Like traditional estuaries, STEs are areas where changes in the chemical nature of the fluid results in flocculation, sedimentation and ion exchange reactions. However, STEs may also have very different chemical characteristics than traditional estuaries because of a lack of communication with the atmosphere and reaction with the sediment matrix over the relatively long transit times of the flowing water. The chemical reactions modify the rock and fluid composition, causing certain major ions to be lost due to the precipitation of minerals while other trace elements $(\mathrm{Fe}, \mathrm{Mn})$, nutrients $(\mathrm{N}, \mathrm{P})$, dissolved organic or inorganic carbon and methane may be released to the coastal ocean. The resulting strong and dynamic chemical gradients in a subterranean estuary may also provide overlapping habitats for microbial populations that are traditionally thought to be separate due to the specific environmental controls on their metabolism. These changes in both chemical composition and biological community interactions may have important effects on the nutrient load of advecting groundwater prior to discharge in to the coastal ocean.

Nutrients delivered to the coastal ocean by groundwater can alter the ecology of the coastal waters as described above in the balance between healthy primary production and eutrophication. The transport or mobilization of nutrients, trace metals, and other compounds may be due to the natural pressure driven flow (including tidal flushing) of 
the groundwater aquifer or may be enhanced due to anthropogenic processes such as reduction of the hydraulic head, thus enhancing salt water intrusion. Many reactions can occur during the intrusion and mixing of salt water into the groundwater aquifer due to the changes in the ionic strength of the solution. Desorption of some bound compounds from the substrate or flocculation and precipitation of other compounds is expected to occur as it does in the mixing zones of surface estuaries. Radium (Ra) is among the compounds that desorb during the mixing process. Seawater naturally contains ${ }^{226} \mathrm{Ra}$ at an activity of $8 \mathrm{dpm} / 100 \mathrm{~L}$ (Moore 1996), any excess of ${ }^{226} \mathrm{Ra}$ in coastal waters must be derived from other sources. Studies have shown, by eliminating other possible sources, that the excess ${ }^{226} \mathrm{Ra}$ is an indicator of groundwater flow into the coastal ocean (Krest et al. 2000). Furthermore, the activity of groundwater ${ }^{226}$ Ra roughly correlates with salinity (more mixing desorbs more Ra) (Moore 1996). It is assumed that this desorption of Ra coincides with desorption of other compounds including dissolved inorganic nitrogen (DIN). Unfortunately, the export of DIN to the coastal ocean does not systematically follow ${ }^{226} \mathrm{Ra}$ enrichments due to other sources and sinks of nitrogen in coastal systems, including nitrogen fixation and nitrogen uptake by vascular plants. Considering these difficulties, Krest et al. (2000) estimate that half of the DIN in coastal waters (extrapolated from a marsh/estuary system) is supplied by groundwater flux. However, physical and chemical processes are not the only factor in controlling the speciation and amount of DIN flux to the coastal ocean. Microbiological processes can also influence DIN export. 
Nitrification, Denitrification and Anaerobic Ammonia Oxidation:

The microbial transformation of fixed nitrogen, mediated by members of the Bacteria and Archaea, involves the processes of nitrogen fixation, nitrification, dissimilatory nitrate reduction to ammonia (DNRA), denitrification, and anaerobic ammonia oxidation, with the latter two processes returning bioavailable nitrogen back to the atmospheric $\mathrm{N}_{2}$ reservoir (Figure 2). These are the major microbial pathways of inorganic nitrogen transformation in the environment.

Nitrification is the microbial transformation of ammonia $\left(\mathrm{NH}_{3}\right)$ to nitrate $\left(\mathrm{NO}_{3}^{-}\right)$ through the intermediates hydroxylamine $\left(\mathrm{NH}_{2} \mathrm{OH}\right)$ and nitrite $\left(\mathrm{NO}_{2}{ }^{-}\right)$. It constitutes an important link between the most reduced $\left(\mathrm{NH}_{3}\right)$ and most oxidized $\left(\mathrm{NO}_{3}{ }^{-}\right)$forms of $\mathrm{N}$ and generates substrates $\left(\mathrm{NO}_{3}{ }^{-}\right.$and $\left.\mathrm{NO}_{2}{ }^{-}\right)$for denitrification and anammox. Nitrification is a multistep process which involves (at least) two distinct metabolic groups of bacteria: ammonia-oxidizing bacteria (AOB) and nitrite-oxidizing bacteria (NOB), though archaea have recently been implicated in ammonia oxidation as well (see below). AOB chemoautotrophically oxidize $\mathrm{NH}_{3}$ to $\mathrm{NO}_{2}{ }^{-}$through the intermediate $\mathrm{NH}_{2} \mathrm{OH}$. This pathway requires two enzymes, ammonia monooxygenase (AMO) and hydroxylamine oxidoreductase ( $\mathrm{HAO}$ ), to conserve energy for $\mathrm{CO}_{2}$ fixation from the production of nitrite. With the exception of Nitrosococcus sp., which are members of the gammaProteobacteria, the majority of the known AOB are beta-Proteobacteria. Thus, until recently, this geochemically important group of microbes was believed to belong to a narrow phylogenetic group (Rotthauwe et al. 1997). Still, with the low abundance of ammonia-oxidizing bacteria in most environments, molecular detection and diversity 
studies have largely relied on characterization of the distribution and diversity of the gene for the alpha subunit of the ammonia monooxygenase ( Kowalchuk et al. 1999; Purkhold et al. 2000; Beman and Francis 2006).

Estuaries present an interesting case study because the mixing of seawater and freshwater creates significant gradients and unique chemical environments. Studies in the Chesapeake Bay and Monterey Bay have shown that the diversity of amoA genes appears to vary with salinity along the estuaries with Nitrosospira-like species restricted to the mid- to high-salinity regions while Nitrosomonas-like species showing no trend (O’Mullan and Ward 2002; Francis et al. 2003). This dependence of ammonia-oxidizer community structure on salinity has implications for our site, where strong salinity gradients co-occur with strong gradients in nitrate and ammonium concentrations.

Much is known about the physiology and biochemistry of bacterial ammoniaoxidizers, such as their growth substrates, sensitivity to light, and ability to grow at low oxygen tensions. Indeed, cultured AOB are capable of growth on dissolved oxygen levels as low as $6 \mu \mathrm{M}$ (Carlucci and McNally 1969; Goreau et al. 1980; Lipschultz et al. 1981). These fundamental characteristics of $\mathrm{AOB}$ have shaped our view of when and where nitrification may be an important player in nitrogen transformations. However, AOB often account for only $0.1 \%$ of the community in pelagic and benthic oceanic environments (Ward 2000). The abundance of AOB is thus not representative of the importance of the nitrogen transformation that they mediate which ultimately leads to oxidized nitrogen availability for removal processes such as denitrification. 
Denitrification is the stepwise reduction of nitrate to dinitrogen through the intermediates nitrite, nitric oxide and nitrous oxide. Because of the requirement for a supply of oxidized nitrogen compounds, denitrification is often found coupled to nitrification across sediment oxyclines. Denitrifiers are facultative anaerobic heterotrophs and chemoautotrophs found in all three domains of life. The diverse nature of denitrifying microbes and their close phylogenetic affiliation to non-denitrifying bacteria and archaea require the use of functional gene targets to analyze the diversity of denitrifying microbes. Unlike the amoA gene, the genes that encode the proteins required for denitrification are taxonomically widespread and do not corroborate the phylogeny built by 16S rRNA genes, implying horizontal gene transfer (Jose and David 1999; Song and Ward 2003). The enzymes of interest for molecular surveys have traditionally been nitrite reductase (nirS, nirK genes) (Braker et al. 2000; Braker et al. 2001) nitric oxide reductase (norB gene) (Braker and Tiedje 2003; Casciotti and Ward 2005) and nitrous oxide reductase (nosZ gene) (Scala and Kerkhof 1998; Scala and Kerkhof 1999). Interestingly, the diversity of the denitrifying population has been shown to relate to the carbon content (quantity and age) of the sediment, rather than geochemical gradients, with greater diversity occurring in coastal sediment where carbon loads are both greater and younger (Braker et al. 2000; Braker et al. 2001).

Anammox, or anaerobic ammonia oxidation, involves the oxidation of ammonium with nitrite with the electron acceptor and dinitrogen as the end product (Van de Graaf et al. 1995; Jetten et al. 2001; Dalsgaard et al. 2003; Kuypers et al. 2003). Anammox is considered a shunt in the nitrogen cycle because the pathway is capable of removing 
reduced forms of nitrogen without prior oxidation to nitrate. This metabolism was predicted long before organisms capable of it were discovered (Broda 1977). Since then, a representative member of the deeply branching group within the Planctomycetales has been enriched from wastewater treatment facilities and sequenced as part of a community genome (Strous et al. 2006). The anammox process has also recently been shown to be important for nitrogen removal from wastewater treatment systems and in suboxic marine sediments and water columns (Dalsgaard and Thamdrup 2002; Dalsgaard et al. 2003; Kuypers et al. 2003; Dalsgaard et al. 2005; Schmid et al. 2007).

Why Archaea may be important

Archaea have been traditionally thought of as the prokaryotes inhabiting extreme environments such as hot springs, hypersaline lakes, etc. (Woese et al. 1978; Barns et al. 1994). However, Archaea have been show to be abundant in many non-extreme environments including the coastal waters (DeLong 1992) and open ocean waters (Fuhrman 1992), Antarctic water (DeLong et al. 1994; Murray et al. 1999), terrestrial soils (Buckley et al. 1998), freshwater sediments (MacGregor et al. 1997) and even within sponge tissues in symbiosis (Preston et al. 1996). In fact, Archaea may account for $20-40 \%$ of the marine picoplankton (DeLong et al. 1994; Karner et al. 2001). The nonthermophilic crenarchaeota are the most widely distributed and abundant archaea on the planet (DeLong 1998).

The distribution of archaea in the marine environment has been a focus of the early inquiries into this third domain of life. Open ocean 16S rRNA gene surveys have 
shown that below the euphotic zone $(>150 \mathrm{~m})$ the abundance of crenarchaeota constitute the major fraction of the picoplankton and by $1000 \mathrm{~m}$ reach number equal to their bacterial counterparts (Massana et al. 1997; Karner et al. 2001). Due to hybridization of or cellular $16 \mathrm{~S}$ rRNA it has been estimated that $60-80 \%$ of the microorganisms present in the water column are metabolically active (Karner et al. 2001). However, without cultured representatives of non-extreme organisms it was difficult to ascertain the ecological role of the archaeal biomass in the environment. Interestingly, positive correlations between crenarchaeal distribution and nitrite were observed in the Arabian Sea (Damste et al. 2002), coastal ocean (Murray et al. 1999), and in low oxygen conditions in the Black Sea (Coolen et al. 2007). Enrichment culture obtained from the North Sea showed increases in crenarchaeota and amoA gene abundances coinciding with the loss of ammonium and generation of nitrite (Wuchter et al. 2006).

More recently, genomic surveys have shed light on to the potential ecology of marine crenarchaeota. Shotgun libraries from the Sargasso Sea discovered the presence of amoA on a scaffold containing archaeal-linked genes (Venter et al. 2004). This finding suggested that some pelagic, marine archaea might be capable of nitrification. Subsequently, Sargasso Sea-like amoA genes (archaeal amoA genes) were later found to occur with 16S rRNA genes from crenarchaeota in a large genomic fragment isolated from soils (Schleper et al. 2005; Leininger et al. 2006). Archaeal amoA genes have also been found in marine waters and sediments, including Elkhorn Slough, CA estuary sediments (Francis et al. 2005). Additional work has resulted in the cultivation of the first ammonia oxidizing archaea (AOA) related to the abundant Marine Group I 
Crenarchaeota (MGI)(Konneke et al. 2005), demonstrating unambiguously that a marine archaeon is able to conserve energy chemolithoautotrophically by oxidizing ammonia. Finally, Wuchter et al. (2006) conclusively showed that the loss of nitrate from the water column of the North Sea is correlated with archaeal cell and archaeal amoA abundance while bacterial amoA genes occurred at much lower levels.

Contrary to their environmental abundance their ecology and activities are less well understood. For example, it is known that $\mathrm{AOB}$ are inhibited by high light but it is unknown if AOA have the same sensitivity. There is also some evidence that AOA may not be strict autotrophs as genomic evidence suggests they may be able to metabolize organic carbon as well as carbon dioxide in a mixotrophic lifestyle. What is known about their physiologic capacity comes from only a handful of laboratory cultures and observations of their distributions in a range of environments. Research has shown AOA can range in temperature from mesophilic (Konneke et al. 2005) to thermophilic (de la Torre et al. 2008). Their ecological significance has been the focus of studies in recent years, almost always in comparison to their bacterial counter parts. Relative changes in abundance between the two groups has been correlated with salinity and oxygen (Beman and Francis 2006; Mosier and Francis 2008; Santoro et al. 2008), C:N (Mosier and Francis 2008), as well as trace metal availability (lead and nickel) (Caffrey et al. 2007; Mosier and Francis 2008).However, to date there is not one master variable that seems to determine AOA abundance. 


\section{Research Approach}

Subterranean estuaries are the last line of defense against nitrogen-polluted groundwater seeping into the coastal ocean through SGD, and microbial nitrogen removal may provide an important environmental service in these settings. Unfortunately, little is known about the microbial community responsible for nitrogen transformations in subterranean estuaries. The primary objectives of this study are to determine the diversity, abundance and distribution of bacteria and archaea involved in nitrification and denitrification in the Waquoit Bay subterranean groundwater estuary and to determine the potential environmental rates of these processes. Insight into these processes, the distribution and activity of the microorganisms involved, will allow a better assessment of nitrogen loading in coastal waters and the natural processes that may attenuate this load.

To begin this effort the microbial communities responsible for nitrification and their distribution in the groundwater system must be described. Chapter 2 surveys the abundance and distribution of bacterial and archaeal 16S rRNA and amo $A$ genes throughout a sediment core taken at Waquoit Bay in June 2008. The phylogenetic distributions of the archaeal amoA genes are also presented. The results of this work show that archaeal 16S rRNA gene abundance accounts for more than $70 \%$ of the cells deep in the sediment column, as the pore water transition from fresh groundwater to the deep salt wedge. Looking at Marine Group I Crenarchaeota, a subset of the total archaeal population that includes the AOA, a slightly different pattern emerges. MGI 16S rRNA genes show two peaks in abundance, one in the upper 0.5 meter and again at 3 meters, 
just above the deep salt wedge. The distribution of archaeal amo $A$ genes is consistent with that of MGI 16S rRNA genes with a roughly 1:1 ratio. Bacterial amoA gene abundance peaked in the core of the freshwater plume where it accounted for the majority of the total amoA genes. This chapter also includes the first experimental comparison of archaeal $a m o A$ primer sets, an important contribution to the field in that it provides a basis for the interpretation of published data sets with differing primer sets and reaction conditions.

Having addressed who and where the nitrifying communities are in the aquifer, Chapter 3 focuses on the role of denitrification in the system. To do this we describe the chemistry of the pore waters along a shore-normal transect as well as the abundance of nitrite reductase genes (nirS and nirK) down core. Included among the transect data are natural abundance isotopic measurement of $\delta^{15} \mathrm{~N}_{\mathrm{NO} 3}, \delta^{18} \mathrm{O}_{\mathrm{NO} 3}$ and $\delta^{18} \mathrm{O}_{\mathrm{H} 20}$. The data shows a loss of nitrate occurs in the upper meter of the sediment column. While nitrate decreases the $\delta^{15} \mathrm{~N}_{\mathrm{NO} 3}$ and $\delta^{18} \mathrm{O}_{\mathrm{NO} 3}$ increase in a ratio indicative of denitrification in a sandy aquifer. Unfortunately, due to the steep nitrate gradient transitioning from the freshwater plume into the deep salt wedge natural abundance isotopic measurements are not available over this transition. NirK is the dominant denitrification gene in the surface meter while nirS increases rapidly entering into the deep salt wedge. This change in gene abundance indicates a change in the denitrification community from the surface to deep salt wedge. This change may be due to organic carbon or some other environmental characteristic. 
The goal of Chapter 4 was to measure potential rates of nitrification in relation to the gene profiles reported in Chapter 2. We employ the use of ${ }^{15} \mathrm{~N}$ tracers to track the transfer of nitrogen between pools and calculate the rates involved based on the transfer rates. ${ }^{15} \mathrm{~N}$-labeled ammonium was added to the tracer experiment at a level of $50 \mu \mathrm{M}$ and 99.5-atom \%. The transfer of label between the ammonium and nitrate (no nitrite was evident) pools was followed along with transcription of specific functional genes for nitrification. We show that the surface meter is a zone of nitrification mediated by AOA with rates significantly faster than open ocean water column nitrification but slower than nitrification in coastal sediments. In the core of the freshwater plume $(2 \mathrm{~m})$ we find AOB are the abundant nitrifiers with potential rates equivalent to those observed in the surface sediments. At the boundary between the freshwater and deep salt wedge, where a large population of AOA had been described in Chapter 2, we find no chemical evidence for nitrification. This raises some interesting questions as to if these organisms are active at this depth and if so what ecological function are they fulfilling?

In total, the data presented in the following chapters depicts active populations of nitrifiers and denitrifiers present in the aquifer, with regions of potential overlap in the upper meter. In the heart of the large nitrate plume, nitrification appears to be active while denitrification is limited in this portion of the aquifer. Of course, much if not all of this fresh groundwater will mix with seawater prior to discharge. If the communities and activities at this mixing front behave similar to the communities in the upper meter of the aquifer, these organisms may have dramatic effects on the DIN pools discharged into Waquoit Bay. 


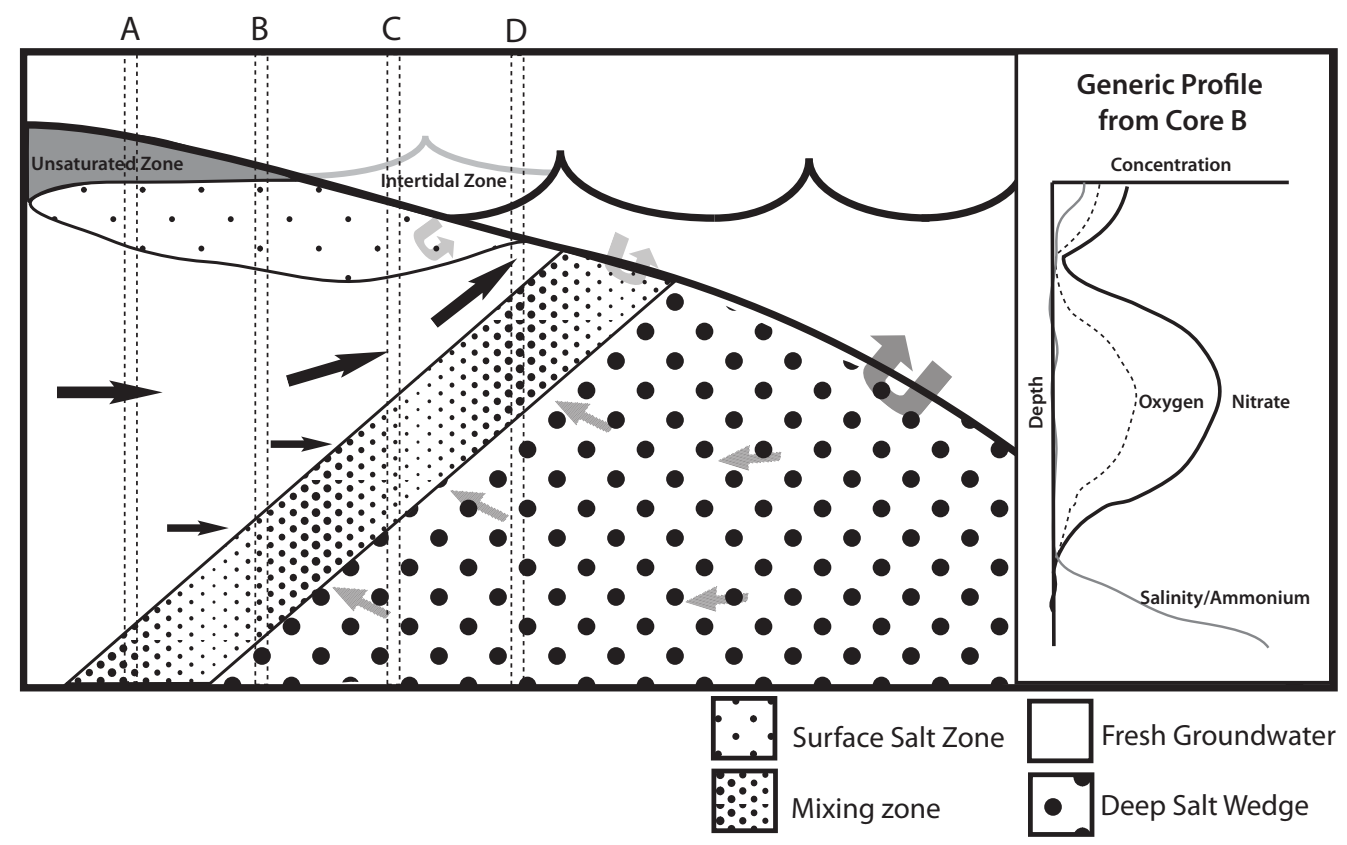

Figure 1. Sampling schematic depicting the relative position of the piezometer locations (A, B, C , D) in relation to the aquifer structure. The aquifer is composed of three distinct water parcels, (1) a surface salt zone (stippled), (2) a fresh groundwater plume (white) and (3) a deep salt wedge (large stipples). The mixing zone between the freshwater and deep salt wedge is noted with a gradient in stippling. Pulse-coring was performed at site $\mathrm{B}$ during June 2008. The inset shows the idealized relative concentration variations in nitrate, oxygen, salinity and ammonium with depth in the aquifer near site B. 


\section{Bacterial-Mediated Nitrogen Cycle}

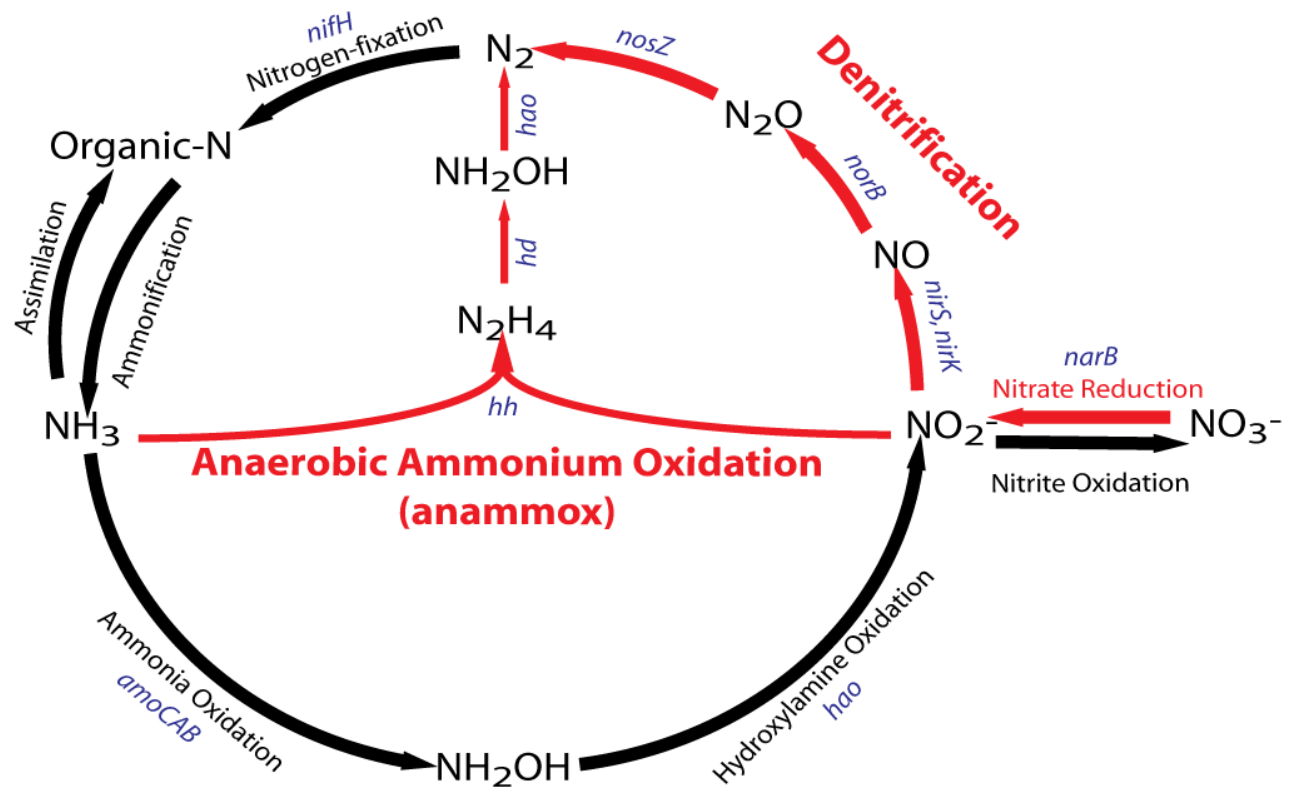

Archaeal-Mediated Nitrogen Cycle

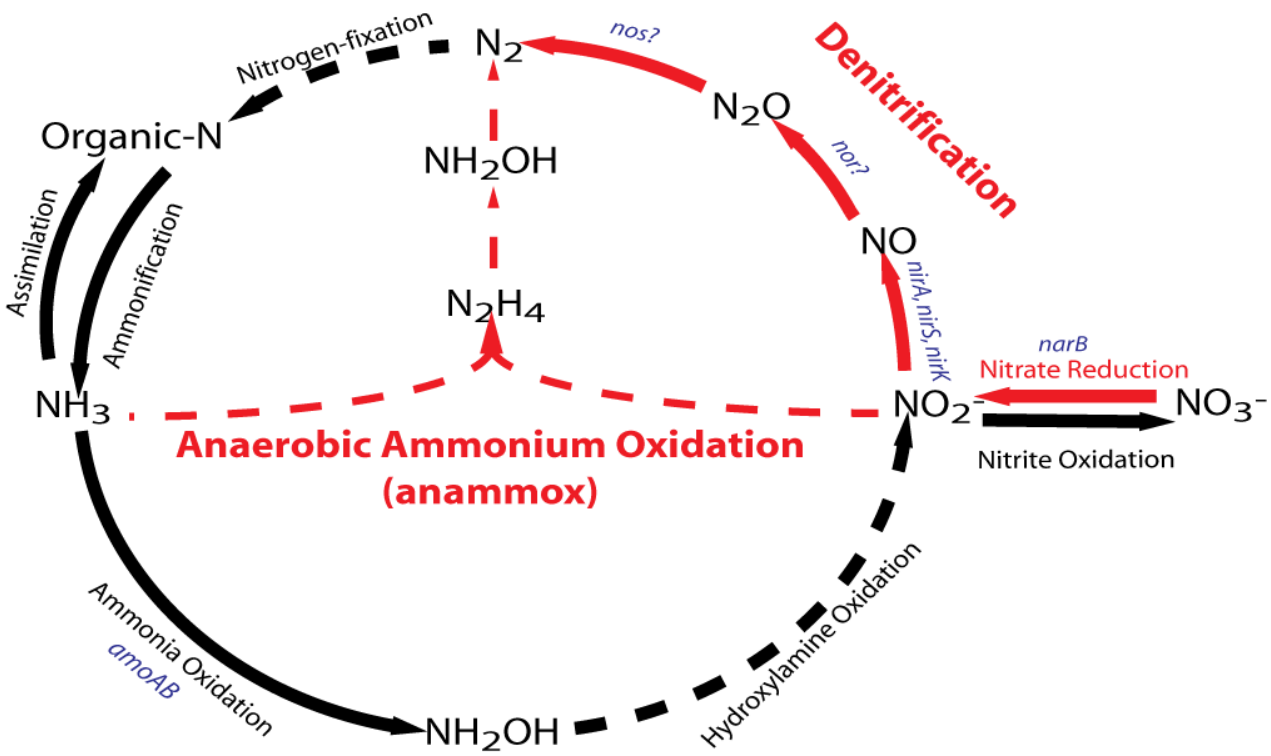

Figure 2. A view of the microbially-mediated N-cycles. Known genes for each pathway are shown in blue, anaerobic $\mathrm{N}$-evolving pathways are shown in red. Dashed pathways in the archaeal-mediated $\mathrm{N}$-cycle indicate that evidence of these pathways has yet to be reported. 


\section{References}

Barns, S. M., R. E. Fundyga, M. W. Jeffries and N. R. Pace (1994). "Remarkable archaeal diversity detected in a Yellowstone National Park hot spring environment." Proc Natl Acad Sci U S A 91(5): 1609-1613.

Beman, J. M. and C. A. Francis (2006). "Diversity of ammonia-oxidizing archaea and bacteria in the sediments of a hypernutrified subtropical estuary: Bahia del Tobari, Mexico." Appl. Environ. Microbiol. 72(12): 7767-7777.

Braker, G., H. L. Ayala-del-Río, A. H. Devol, A. Fesefeldt and J. Tiedje (2001). "Community structure of denitrifiers, Bacteria and Archaea along redox gradients in Pacific Northwest marine sediments by terminal restriction fragment length polymorphism analysis of amplified nitrite reductase (nirS) and 16S rRNA genes." Applied and Environmental Microbiology 67(4): 1893-1901.

Braker, G. and J. M. Tiedje (2003). "Nitric Oxide Reductase (norB) Genes from Pure Cultures and Environmental Samples." Appl. Environ. Microbiol. 69(6): 34763483.

Braker, G., J. Zhou, L. Wu, A. H. Devol and J. M. Tiedje (2000). "Nitrite Reductase Genes (nirK and nirS) as Functional Markers To Investigate Diversity of Denitrifying Bacteria in Pacific Northwest Marine Sediment Communities." Applied and Environmental Microbiology 66(5): 2096.

Bricker, S., C. Clement, D. Pirhalla, S. Orlando and D. Farrow (1999). National Estuarine Eutrophication Assessment: effects of nutrient enrichment in the nation's estuaries. N. O. Service, National Oceanic and Atmospheric Administration: 71.

Broda, E. (1977). "Two kinds of lithotrophs missing in nature." Zeitschrift fuer Allgemeine Mikrobiologie 17(6): 491-3.

Buckley, D., J. Graber and T. Schmidt (1998). "Phylogenetic analysis of nonthermophilic members of the kingdom Crenarchaeota and their diversity and abundance in soils." Applied and Environmental Microbiology 64(11): 4333.

Bugna, G., J. Chanton, J. Cable, W. Burnett and P. Cable (1996). "The importance of groundwater discharge to the methane budgets of nearshore and continental shelf waters of the northeastern Gulf of Mexico." Geochimica et Cosmochimica Acta 60(23): 4735-4746.

Burnett, W. C., H. Bokuniewicz, M. Huettel, W. S. Moore and M. Taniguchi (2003). "Groundwater and pore water inputs to the coastal zone." Biogeochemistry 66(1 2): 3 .

Cable, J. E. and J. B. Martin (2008). "In situ evaluation of nearshore marine and fresh pore water transport into Flamengo Bay, Brazil." Estuarine, Coastal and Shelf Science 76(3): 473-483.

Caffrey, J. M., N. Bano, K. Kalanetra and J. T. Hollibaugh (2007). "Ammonia oxidation and ammonia-oxidizing bacteria and archaea from estuaries with differing histories of hypoxia." ISME Journal 1(7): 660-662.

Carlucci, A. and P. McNally (1969). "Nitrification by marine bacteria in low concentrations of substrate and oxygen." Limnology and Oceanography 14(5): 736-739. 
Casciotti, K. L. and B. B. Ward (2005). "Phylogenetic analysis of nitric oxide reductase gene homologues from aerobic ammonia-oxidizing bacteria." FEMS Microbiology Ecology 52(2): 197-205.

Charette, M. A., K. O. Buesseler and J. E. Andrews (2001). "Utility of radium isotopes for evaluating the input and transport of groundwater-derived nitrogen to a Cape Cod estuary." Limnology and Oceanography 46(2): 465-470.

Coolen, M. J. L., B. Abbas, J. van Bleijswijk, E. C. Hopmans, M. M. M. Kuypers, S. G. Wakeham and J. S. Sinninghe Damste (2007). "Putative ammonia-oxidizing Crenarchaeota in suboxic waters of the Black Sea: a basin-wide ecological study using $16 \mathrm{~S}$ ribosomal and functional genes and membrane lipids." Environmental Microbiology 9(4): 1001-1016.

Dalsgaard, T., D. E. Canfield, J. Petersen, B. Thamdrup and J. Acuna-Gonzalez (2003). "N2 production by the anammox reaction in the anoxic water column of Golfo Dulce, Costa Rica." Nature 422(6932): 606-8.

Dalsgaard, T. and B. Thamdrup (2002). "Factors Controlling Anaerobic Ammonium Oxidation with Nitrite in Marine Sediments." Appl. Environ. Microbiol. 68(8): 3802-3808.

Dalsgaard, T., B. Thamdrup and D. E. Canfield (2005). "Anaerobic ammonium oxidation (anammox) in the marine environment." Res Microbiol 156(4): 457-64.

Damste, S., S. Jaap, W. Rijpstra, E. Hopmans, F. Prahl, S. Wakeham and S. Schouten (2002). "Distribution of membrane lipids of planktonic Crenarchaeota in the Arabian Sea." Applied and Environmental Microbiology 68(6): 2997-3002.

de la Torre, J. R., C. B. Walker, A. E. Ingalls, M. Konneke and D. A. Stahl (2008). "Cultivation of a thermophilic ammonia oxidizing archaeon synthesizing crenarchaeol." Environmental Microbiology 10(3): 810-818.

DeLong, E., K. Wu, B. PrÈzelin and R. Jovine (1994). "High abundance of Archaea in Antarctic marine picoplankton." Nature 371(6499): 695-697.

DeLong, E. F. (1992). "Archaea in Coastal Marine Environments." PNAS 89(12): 56855689.

DeLong, E. F. (1998). "Everything in moderation: Archaea as 'non-extremophiles'." Current Opinion in Genetics \& Development 8(6): 649-654.

EPA (2001). National coastal condition report, U.S. Environmental Protection Agency.

Francis, C. A., G. D. Mullan and B. B. Ward (2003). "Diversity of ammonia monooxygenase (amoA) genes across environmental gradients in Chesapeake Bay sediments." Geobiology 1(2): 129-140.

Francis, C. A., K. J. Roberts, J. M. Beman, A. E. Santoro and B. B. Oakley (2005). "Ubiquity and diversity of ammonia-oxidizing archaea in water columns and sediments of the ocean." PNAS 102(41): 14683-14688.

Fuhrman, J. (1992). "Novel major archaebacterial group from marine plankton." Nature 356: $148-149$.

Goreau, T. J., W. A. Kaplan, S. C. Wofsy, M. B. McElroy, F. W. Valois and S. W. Watson (1980). "Production of NO2-and N2O by Nitrifying Bacteria at Reduced Concentrations of Oxygen." Applied and Environmental Microbiology 40(3): 526-532. 
Hall, S., S. Luttrell and W. Cronin (1991). "Method for estimating effective porosity and ground-water velocity." Ground Water 29(2): 171-174.

Howarth, R. W., A. Sharpley and D. Walker (2002). "Sources of nutrient pollution to coastal waters in the United States: Implicatoins for achieving coastal water quality goals." Estuaries 45(4b): 656-676.

Jetten, M., M. Wagner, J. Fuerst, M. van Loosdrecht, G. Kuenen and M. Strous (2001). "Microbiology and application of the anaerobic ammonium oxidation (anammox) process." Current Opinion in Biotechnology 12(3): 283-288.

Jose, C. and M. David (1999). "Respiratory Chains in the Last Common Ancestor of Living Organisms." Journal of Molecular Evolution V49(4): 453.

Karner, M. B., E. F. DeLong and D. M. Karl (2001). "Archaeal dominance in the mesopelagic zone of the Pacific Ocean." Nature 409(6819): 507.

Konneke, M., A. E. Bernhard, J. R. de la Torre, C. B. Walker, J. B. Waterbury and D. A. Stahl (2005). "Isolation of an autotrophic ammonia-oxidizing marine archaeon." Nature 437(7058): 543.

Kowalchuk, G. A., Z. S. Naoumenko, P. J. L. Derikx, A. Felske, J. R. Stephen and I. A. Arkhipchenko (1999). "Molecular Analysis of Ammonia-Oxidizing Bacteria of the beta -Subdivision of the Class Proteobacteria in Compost and Composted Materials." Appl. Environ. Microbiol. 65(2): 396-403.

Krest, J., W. S. Moore and L. Gardner (2000). "Marsh nutrient export supplied by groundwater discharge: Evidence from radium measurements." Global Biogeochemical Cycles 14(1): 167-176.

Kuypers, M., A. Sliekers, G. Lavik, M. Schmid, B. J ${ }^{-}$rgensen, J. Kuenen, J. DamstÈ, M. Strous and M. Jetten (2003). "Anaerobic ammonium oxidation by anammox bacteria in the Black Sea." Nature 422(6932): 608-611.

Kuypers, M. M. M., A. O. Sliekers, G. Lavik, M. Schmid, B. B. Jorgensen, J. G. Kuenen, J. S. Sinninghe Damste, M. Strous and M. S. M. Jetten (2003). "Anaerobic ammonium oxidation by anammox bacteria in the Black Sea." Nature 422(6932): 608.

Leininger, S., T. Urich, M. Schloter, L. Schwark, J. Qi, G. W. Nicol, J. I. Prosser, S. C. Schuster and C. Schleper (2006). "Archaea predominate among ammoniaoxidizing prokaryotes in soils." Nature 442(7104): 806.

Lipschultz, F., O. C. Zafiriou, S. C. Wofsy, M. B. McElroy, F. W. Valois and S. W. Watson (1981). "Production of NO and N2O by soil nitrifying bacteria." Nature 294(5842): 641-643.

MacGregor, B., D. Moser, E. Alm, K. Nealson and D. Stahl (1997). "Crenarchaeota in lake Michigan sediment." Applied and Environmental Microbiology 63(3): 1178.

Massana, R., A. Murray, C. Preston and E. DeLong (1997). "Vertical distribution and phylogenetic characterization of marine planktonic Archaea in the Santa Barbara Channel." Applied and Environmental Microbiology 63(1): 50-56.

Michael, H., J. Lubetsky and C. Harvey (2003). "Characterizing submarine groundwater discharge: A seepage meter study in Waquoit Bay, Massachusetts." Geophysical Research Letters 30(6): 1297. 
Milliman, J. D. (1993). "Production and Accumulation of Calcium-Carbonate in the Ocean - Budget of a Nonsteady State." Global Biogeochemical Cycles 7(4): 927957.

Moore, W. (2006). "The role of submarine groundwater discharge in coastal biogeochemistry." Journal of Geochemical Exploration 88(1-3): 389-393.

Moore, W. S. (1996). "Large groundwater inputs to coastal waters revealed by ${ }^{226} \mathrm{Ra}$ enrichments." Nature 380: 612-614.

Moore, W. S. (1999). "The subterranean estuary: A reaction zone of ground water and sea water." Marine Chemistry 65: 111-125.

Moore, W. S., J. L. Sarmiento and R. M. Key (2008). "Submarine groundwater discharge revealed by 228Ra distribution in the upper Atlantic Ocean." Nature Geosci 1(5): 309-311.

Mosier, A. C. and C. A. Francis (2008). "Relative abundance and diversity of ammoniaoxidizing archaea and bacteria in the San Francisco Bay estuary." Environmental Microbiology 10(11): 3002-3016.

Murray, A., A. Blakis, R. Massana, S. Strawzewski, U. Passow, A. Alldredge and E. DeLong (1999). "A time series assessment of planktonic archaeal variability in the Santa Barbara Channel." Aquatic Microbial Ecology 20(2): 129-145.

Murray, A., K. Wu, C. Moyer, D. Karl and E. DeLong (1999). "Evidence for circumpolar distribution of planktonic Archaea in the Southern Ocean." Aquatic Microbial Ecology 18(3): 263-273.

O’Mullan, G. D. and B. B. Ward (2002). "Nitrification rates and diversity of ammonia oxidizing bacteria in Monterey Bay, California." Eos, Transactions, American Geophysical Union 83(4).

Preston, C., K. Wu, T. Molinski and E. DeLong (1996). "A psychrophilic crenarchaeon inhabits a marine sponge: Cenarchaeum symbiosum gen. nov., sp. nov." Proceedings of the National Academy of Sciences 93(13): 6241.

Purkhold, U., A. Pommerening-Roser, S. Juretschko, M. C. Schmid, H.-P. Koops and M. Wagner (2000). "Phylogeny of All Recognized Species of Ammonia Oxidizers Based on Comparative 16S rRNA and amoA Sequence Analysis: Implications for Molecular Diversity Surveys." Appl. Environ. Microbiol. 66(12): 5368-5382.

Rotthauwe, J. H., K. P. Witzel and W. Liesack (1997). "The ammonia monooxygenase structural gene amoa as a functional marker: Molecular fine-scale analysis of natural ammonia-oxidizing populations." Applied and Environmental Microbiology 63(12): 4704.

Santoro, A. E., C. A. Francis, N. R. de Sieyes and A. B. Boehm (2008). "Shifts in the relative abundance of ammonia-oxidizing bacteria and archaea across physicochemical gradients in a subterranean estuary." Environmental Microbiology 10(4): 1068-1079.

Scala, D. J. and L. J. Kerkhof (1998). "Nitrous oxide reductase (nosZ) gene-specific PCR primers for detection of denitrifiers and three nosZ genes from marine sediments." FEMS Microbiology Letters 162(1): 61-68. 
Scala, D. J. and L. J. Kerkhof (1999). "Diversity of Nitrous Oxide Reductase (nosZ) Genes in Continental Shelf Sediments." Appl. Environ. Microbiol. 65(4): 16811687.

Schleper, C., G. Jurgens and M. Jonuscheit (2005). "Genomic studies of uncultivated archaea." Nature Reviews Microbiology 3(6): 479.

Schmid, M. C., N. Risgaard-Petersen, J. van de Vossenberg, M. M. M. Kuypers, G. Lavik, J. Petersen, S. Hulth, B. Thamdrup, D. Canfield, T. Dalsgaard, S. Rysgaard, M. K. Sejr, M. Strous, H. J. M. Op den Camp and M. S. M. Jetten (2007). "Anaerobic ammonium-oxidizing bacteria in marine environments: widespread occurrence but low diversity." Environmental Microbiology 9(6): 1476-1484.

Sholkovitz, E., C. Herbold and M. Charette (2003). "An automated dye-dilution based seepage meter for the time-series measurement of submarine groundwater discharge." Limnol. Oceanogr. Methods 1: 16-28.

Song, B. and B. B. Ward (2003). "Nitrite reductase genes in halobenzoate degrading denitrifying bacteria." FEMS Microbiology Ecology 43(3): 349-357.

Spiteri, C., C. Slomp, K. Tuncay and C. Meile (2008). "Modeling biogeochemical processes in subterranean estuaries: Effect of flow dynamics and redox conditions on submarine groundwater discharge of nutrients." Water Resources Research 44(2).

Strous, M., E. Pelletier, S. Mangenot, T. Rattei, A. Lehner, M. W. Taylor, M. Horn, H. Daims, D. Bartol-Mavel, P. Wincker, V. Barbe, N. Fonknechten, D. Vallenet, B. Segurens, C. Schenowitz-Truong, C. Medigue, A. Collingro, B. Snel, B. E. Dutilh, H. J. M. Op den Camp, C. van der Drift, I. Cirpus, K. T. van de PasSchoonen, H. R. Harhangi, L. van Niftrik, M. Schmid, J. Keltjens, J. van de Vossenberg, B. Kartal, H. Meier, D. Frishman, M. A. Huynen, H.-W. Mewes, J. Weissenbach, M. S. M. Jetten, M. Wagner and D. Le Paslier (2006). "Deciphering the evolution and metabolism of an anammox bacterium from a community genome." Nature 440(7085): 790.

Swarzenski, P., M. Charette, D. Christian and G. Survey (2004). An autonomous, electromagnetic seepage meter to study coastal groundwater/surface-water exchange, US Geological Survey.

Thompson, C., L. Smith and R. Maji (2007). "Hydrogeological modeling of submarine groundwater discharge on the continental shelf of Louisiana." J. Geophys. Res. 112(C3): C03014.

Valiela, I., J. Costa, K. Foreman, J. Teal, B. Howes and D. Aubrey (1990). "Transport of groundwater-borne nutrients from watersheds and their effects on coastal waters." Biogeochemistry 10: 177-197.

Valiela, I., K. Foreman, M. LaMontagne, D. Hersh, J. Costa, P. Peckol, B. DeMeoAndreson, C. D'Avanzo, M. Babione, C.-H. Sham, J. Brawley and K. Lajtha (1992). "Couplings of watersheds and coastal waters: Sources and consequences of nutrient enrichment in Waquoit Bay, Massachusetts." Estuaries 15(4): 443-457. 
Van de Graaf, A., A. Mulder, P. De Bruijn, M. Jetten, L. Robertson and J. Kuenen (1995). "Anaerobic oxidation of ammonium is a biologically mediated process." Applied and Environmental Microbiology 61(4): 1246.

Venter, J. C., K. Remington, J. F. Heidelberg, A. L. Halpern, D. Rusch, J. A. Eisen, D. Wu, I. Paulsen, K. E. Nelson, W. Nelson, D. E. Fouts, S. Levy, A. H. Knap, M. W. Lomas, K. Nealson, O. White, J. Peterson, J. Hoffman, R. Parsons, H. BadenTillson, C. Pfannkoch, Y.-H. Rogers and H. O. Smith (2004). "Environmental genome shotgun sequencing of the Sargasso Sea." Science 304(5667): 66-74.

Ward, B. B. (2000). Nitrification and the marine nitrogen cycle. Microbial ecology of the oceans. D. L. Kirchman. New York, NY, Wiley-Liss: 427-454.

Woese, C., L. Magrum and G. Fox (1978). "Archaebacteria." Journal of Molecular Evolution 11(3): 245-252.

Wuchter, C., B. Abbas, M. J. L. Coolen, L. Herfort, J. van Bleijswijk, P. Timmers, M. Strous, E. Teira, G. J. Herndl, J. J. Middelburg, S. Schouten and J. S. Sinninghe Damste (2006). "Archaeal nitrification in the ocean." PNAS 103(33): 1231712322.

Zektser, I. S. and H. A. Loaiciga (1993). "Groundwater fluxes in the global hydrologic cycle: past, present and future." Journal of Hydrology 144(1-4): 405. 
Chapter 2: Abundance and diversity of archaeal ammonia-oxidizers in a coastal groundwater aquifer.

\author{
Daniel R. Rogers ${ }^{\dagger \dagger^{*}}$, Karen L. Casciotti ${ }^{\dagger}$
}

${ }^{\dagger}$ Department of Marine Chemistry and Geochemistry and ${ }^{\dagger}$ MIT/WHOI Joint Program in Chemical Oceanography, Woods Hole Oceanographic Institution, Woods Hole MA 02543.

${ }^{*}$ Corresponding author

phone: 508-289-3748

fax: 508-457- 2076

email: drogers@whoi.edu

Submitted to Applied and Environmental Microbiology 


\begin{abstract}
This study demonstrates that Archaea are abundant members of the microbial community throughout a $4 \mathrm{~m}$ sediment core of the Waquoit Bay (Cape Cod, MA) groundwater aquifer, constituting $50 \%$ or more of the total $16 \mathrm{~S}$ rRNA gene copies at each depth examined in the groundwater aquifer. 16S rRNA gene sequence analyses of the archaeal populations showed large contributions from both Euryarchaeota (Methanosarcinaleslike) and Crenarchaeota (primarily Cenarchaeales-like). As part of this study, the result from four published sets of archaeal ammonia monooxygenase subunit A (amoA)targeted qPCR primers were compared. While the results of the different primer sets were generally consistent, the Treusch et al. primer set detected fewer amo $A$ copies below $2 \mathrm{~m}$ depth than the three other primer sets. Quantitative PCR results for both 16S rRNA and amo $A$ genes revealed that ammonia-oxidizing archaea were more abundant than their bacterial counterparts at most depths within the aquifer. Ammonia-oxidizing bacteria were dominant at only one depth, corresponding to the core of the freshwater plume and nitrate peak, where they accounted for approximately $80 \%$ of the amo $A$ containing community. From archaeal amoA clone libraries we found that the ammonia-oxidizing population from the surface salt zone of the aquifer was characterized by amo $A$ gene sequences most closely related to those obtained from low-salinity estuarine sediments. On the other hand, the archaeal amoA population from the deep salt wedge was dominated by sequences most closely related to those recovered from soils and groundwater.
\end{abstract}




\section{Introduction}

Delivery of excess nitrogen to coastal ecosystems can result in a myriad of deleterious effects ranging from excessive or harmful algal blooms to loss of sea grass habitat, hypoxia, and loss of fish stocks (Tomasky et al. 1999). One route of nitrogen input into coastal water is through submarine groundwater discharge, which can also include seawater recirculated through coastal sediments (Moore 2006). Mechanisms of microbiological transformation of the nitrogen-containing compounds within the groundwater aquifer prior to discharge are therefore of interest because they can influence both the quantity and composition of the nitrogen input to coastal waters.

Reduced nitrogen is often introduced to groundwater as ammonia or organic nitrogen that is subsequently catabolized to ammonia. Nitrification is the microbiallymediated oxidation of reduced nitrogen (principally ammonium) to nitrite $\left(\mathrm{NO}_{2}{ }^{-}\right)$and ultimately to nitrate $\left(\mathrm{NO}_{3}{ }^{-}\right)$. This process is important in controlling the speciation of nitrogen between the reduced and the oxidized forms, which can ultimately be removed from the environment through denitrification. Nitrification is carried out by at least three groups of microorganisms. Ammonia oxidation to nitrite has been shown to be the metabolic function of specific groups of ammonia-oxidizing bacteria (AOB) (Bothe et al. 2000 ) and, more recently, ammonia-oxidizing archaea (AOA) (Konneke et al. 2005). Nitrite-oxidizing bacteria perform the latter step $\left(\mathrm{NO}_{2}{ }^{-}\right.$to $\left.\mathrm{NO}_{3}{ }^{-}\right)$. The discovery that certain archaea (specifically Marine Group I Crenarchaeota, MG1) that are ubiquitous and abundant in the environment may also harbor genes responsible for ammonia oxidation (Venter et al. 2004; Treusch et al. 2005; Hallam et al. 2006; Leininger et al. 
2006; Wuchter et al. 2006; Schauss et al. 2009) has prompted reconsideration of the roles of bacteria and archaea in the nitrification process and where (the environmental contexts) ammonia oxidation may occur. In this study, we apply molecular techniques to ascertain 1) who the most abundant ammonia-oxidizing organisms are in the Waquoit Bay subterranean estuary (Cape Cod, MA), and 2) where in the gradients of nutrients, salinity, and oxygen within the aquifer the communities are most abundant and diverse.

\section{Materials and Methods}

\section{Study Area and Sample Collection}

The groundwater aquifer at the study site in the Waquoit Bay National Estuarine

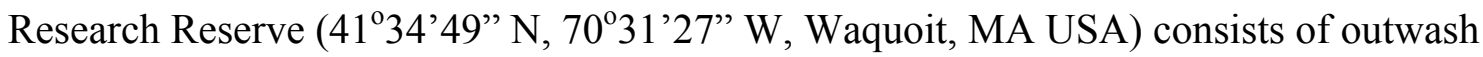
gravel, sand and silt deposited during the retreat of the Wisconsin glaciation (Oldale 1976). The upper $10 \mathrm{~m}$ of sediment are homogeneous and highly permeable, providing conduits for transport of fresh groundwater toward the bay and tidally-forced saltwater intrusions (Charette et al. 2005). The Waquoit Bay groundwater aquifer has been the focus of several studies addressing the importance of the groundwater discharge into the bay for trace metal, nutrient, and pollutant budgets (Valiela et al. 1992; Sham et al. 1995; Charette et al. 2001; Testa et al. 2002; Talbot et al. 2003), and a long-term monitoring program for nutrient advection into the bay has been established at this site (Valiela et al. 1990; McClelland and Valiela 1998; Michael et al. 2003). 
Pore water and Sediment Sampling

Pore water was collected in June 2008 at the head of Waquoit Bay to a depth of 4 $\mathrm{m}$ with a vertical resolution of $15-30 \mathrm{~cm}$ using a piezometer with a stainless steel "Retract-a-tip" (AMS, Idaho). After flushing with at least one liter of pore water (more than 6-fold flushing of tubing volume), $\mathrm{pH}$, dissolved oxygen, salinity and temperature were measured using a YSI 600R multi-probe calibrated following the manufacturer's protocols (Charette and Sholkovitz 2002). These indices were used to guide pore water sampling and sediment coring efforts.

Triplicate pore water samples were collected and filtered through a $0.2 \mu \mathrm{m}$ poresize Sterivex filter for nutrient concentration $\left(\mathrm{NO}_{3}{ }^{-}, \mathrm{NO}_{2}^{-}, \mathrm{NH}_{4}{ }^{+}\right)$analyses. These samples were analyzed within 12 hours upon return to the laboratory. Nitrite concentrations were measured colorimetrically using sulfanilamide and N-(1-napthyl) ethylenediamine (Pai et al. 1990). Nitrate plus nitrite $\left(\mathrm{NO}_{\mathrm{x}}\right)$ concentrations were measured by chemiluminescence following a hot vanadium reduction (Cox 1980; Garside 1982; Garside 1985). Ammonium was measured using the phenolhypochlorite method (Solorzano 1969). After pore water sampling, a sediment core was collected within $0.5 \mathrm{~m}$ of the piezometer using a hand-operated bailer-boring auger (Eijkelkamp, The Netherlands) to a depth of four meters. The coring effort occurred within $1 \mathrm{hr}$ of low tide. The recovered sediment was sampled at 30-50 $\mathrm{cm}$ resolution using aseptic techniques, and approximately 1-5 g of sediment was immediately frozen in liquid nitrogen (on site), and then stored at $-80^{\circ} \mathrm{C}$ in the laboratory for later DNA extraction and analysis. 


\section{DNA Extraction}

DNA extractions were performed in triplicate from $1 \mathrm{~g}$ of sediment using

lysozyme (100 $\left.\mathrm{mg} \mathrm{mL}^{-1}\right)$ and proteinase $\mathrm{K}\left(20 \mathrm{mg} \mathrm{mL}^{-1}\right)$ digestions followed by physical disruption by successive freeze-thaw cycles and phenol:chloroform:isoamyl extraction (Edwards et al. 2000). Extracted DNA was precipitated using isopropyl alcohol and $3 \mathrm{M}$ sodium acetate with final resuspension in $50 \mu \mathrm{L}$ of nuclease-free water or Tris-EDTA buffer (TE). The extracts were quantified at $260 \mathrm{~nm}$ using a Nanodrop spectrophotometer (ThermoFisher Scientific) and diluted to appropriate concentrations (see below) for amplification and quantification by polymerase chain reaction (PCR) methods using nuclease-free water.

\section{Quantitative PCR}

Quantitative PCR (qPCR) was employed to determine the gene copy numbers of bacterial and archaeal 16S rRNA and ammonia monooxygenase subunit A (amoA) genes at 30-50 cm resolution throughout the core (Table 1). Triplicate DNA extractions of each sample were diluted to $10 \mathrm{ng} \mu \mathrm{l}^{-1}$ and amplified using either the iQ SYBR green Supermix (Bio-Rad) or a cocktail consisting of $1 \mathrm{X}$ colorless master mix (Promega, Madison, WI), $10 \mathrm{nM}$ dNTPs (Promega), 0.5 X SBYR-Green I (Invitrogen, Carlsbad CA), 20nM fluorescein (Sigma), $1 \mathrm{mM} \mathrm{MgCl}_{2}$ (Promega), forward and reverse primers (300-1000 nM; Table 1) and 1.25 units of GoTaq Flexi DNA polymerase (Promega). Four different sets of qPCR primers (Francis et al. 2005; Treusch et al. 2005; Wuchter et 
al. 2006; Mincer et al. 2007) were used to analyze the abundance of archaeal amoA (Table 1). All qPCR amplifications were repeated on three separate days with optimized thermal programs using an iCycler thermocycler (Bio-Rad, Hercules, CA) (Table 1). qPCR efficiencies ranged from $88-105 \%$ for all reactions resulting in linear standard curves $\left(r^{2}=0.90-0.99\right)$. Melt curves were performed on all reactions to confirm specificity.

\section{Archaeal amoA Primer Screening}

To examine the target specificity of the four different archaeal amo $A$ gene primer sets from Francis et al. (Francis et al. 2005), Mincer et al. (Mincer et al. 2007), Wuchter et al. (Wuchter et al. 2006) and Treusch et al. (Treusch et al. 2005), the primer sequences were aligned to the $a m o A$ gene sequences reported from the Sargasso Sea WGS (AACY01435967), Nitrosopumilus maritimus SCM1 (YP_001582834) and soil fosmid 54d9 (AJ627422) using the Geneious software package (Drummond et al. 2009). These primer sets were also aligned to the $a m o A$ gene sequences recovered from the Waquoit Bay aquifer sediments to determine the target range and specificity of each primer set.

\section{PCR, Cloning and Sequencing}

For each target gene (archaeal 16S rRNA and archaeal amoA), three replicate amplifications from $0.5 \mathrm{~m}, 1 \mathrm{~m}, 2 \mathrm{~m}, 2.5 \mathrm{~m}, 3 \mathrm{~m}$ and $4 \mathrm{~m}$ were conducted according to published protocols (Table 1 and references therein). The products from each depth were pooled and cleaned with the SV Wizard PCR Clean-up (Promega), ligated following the 
manufacturer's protocols (p-Gem T-Easy vector, Promega), and transformed into chemically competent E. coli JM109 cells. Plasmid purification and sequencing were performed at the Keck Facility, Josephine Bay Paul Center at the Marine Biological Laboratories (JBPC-MBL, Woods Hole, MA). Sequencing chemistry followed a modified Big-Dye reaction containing $0.5 \mu \mathrm{l}$ of Big-Dye Terminator, $0.4 \mu \mathrm{L}$ of primer (M13R 5'-CAGGAAACAGCTATGAC, $15 \mu \mathrm{M}$ ), $0.1 \mu \mathrm{L}$ dimethyl sulfoxide, 1/3 X reaction buffer, template (200-400 ng DNA) and water to a final volume of $6 \mu \mathrm{L}$. The recommended thermal protocol of 60 cycles of $96^{\circ} \mathrm{C}$ for $10 \mathrm{sec} ., 50{ }^{\circ} \mathrm{C}$ for $5 \mathrm{sec}$ and $60{ }^{\circ} \mathrm{C}$ for 4 minutes was used for cycle sequencing.

\section{Sequence analysis}

Base calling and sequence quality checks were performed by the Phred and Phrap software packages (Ewing and Green 1998; Ewing et al. 1998). The Lucy software (Chou and Holmes 2001) was used for vector trimming. Processed sequences were searched against the non-redundant nucleotide (nr/nt) database using the blastn algorithm. Sequences were imported into ARB (Ludwig et al. 2004), aligned with the ARB aligner, manually checked and corrected then added by parsimony to an ARB alignment from Greengenes (16S rRNA genes) or aligned archaeal amo $A$ gene sequences from the GenBank database (Benson et al. 2000). Conservative column filters were constructed masking any sites missing data for any of the sequences. Trees were constructed on aligned sequences using the ARB neighbor joining function. 
Sequence Accession Numbers

All sequences generated and used in this study have been reported to GenBank under the accession numbers HM160162-HM160367.

\section{Results}

\section{Environment Context}

Long-term chemical monitoring has helped to elucidate the biogeochemical setting within the Waquoit Bay subterranean estuary (Charette et al. 2001; Talbot et al. 2003; Charette et al. 2005; Charette and Sholkovitz 2006; Mulligan and Charette 2006; Kroeger and Charette 2008). The most prominent features observed during the current study include (1) a surface brackish layer (salinity up to 4) with low dissolved oxygen $(<50 \mu \mathrm{M})$, nitrate $(<50 \mu \mathrm{M})$ and ammonium $(<5 \mu \mathrm{M})$ concentrations, (2) an oxidized freshwater parcel with high levels of both nitrate (up to $350 \mathrm{mM}$ ) and dissolved oxygen (up to $175 \mu \mathrm{M}$ ), and (3) a deep reducing salt wedge that lacked nitrate but contained up to $53 \mu \mathrm{M}$ ammonium (Figure 1A). These zones provide a variety of niches that could harbor distinct microbial communities adapted to different salinities, oxygen levels, or nutrient concentrations.

\section{$16 S$ rRNA gene abundance}

The abundance of bacterial $16 \mathrm{~S}$ rRNA genes ranged from $3.9 \times 10^{8}$ to $1.3 \times 10^{9}$ copies per gram of sediment with the maximum bacterial 16S rRNA gene abundance observed at two meters depth (Figure 1B). Archaeal 16S rRNA gene abundance was 
comparable with bacterial 16S rRNA genes in the upper 1.7 meters with a range from 4.8 x $10^{8}$ to $7.3 \times 10^{8}$ copies per gram of sediment. Below 1.7 meters, the archaeal $16 \mathrm{~S}$ rRNA gene abundance increased gradually, reaching a maximum of $6.3 \times 10^{9}$ copies per gram of sediment (13-fold increase) by three meters depth.

Taking a closer look at the archaeal subgroup MG1, using specific qPCR primers (Mincer et al. 2007), we found a two order of magnitude range in abundance of MG1 (4.5 $\mathrm{x} 10^{4}$ to $9.8 \times 10^{6}$ copies $\mathrm{g}^{-1}$ sediment ) over the studied depth interval. Based on these qPCR data, MG1 apparently accounted for less than one percent of the total archaeal $16 \mathrm{~S}$ rRNA genes at all but the shallowest depths. However, this minor contribution to the community abundance was not observed in the clone libraries (see below), perhaps indicating an overestimation of total archaeal abundance. MG1 16S rRNA gene abundance follows archaeal $a m o A$ gene abundance in a nearly 1:1 ratio except for the deepest depth. This consistency is also seen in other studies (for example Mincer et al. 2007) and shows our estimation of these genes is likely robust. Unlike the profile of total archaeal abundance, the abundance of MG1 Crenarchaea showed two peaks in the sediment column (Figure 1B). The first peak occurred within the surface meter, reaching an abundance of $8.2 \times 10^{6}$ copies per gram of sediment. MG1 abundance then declined steadily into the middle portions of the sediment core, reaching a minimum of $4.5 \times 10^{4}$ copies per gram of sediment at $1.7 \mathrm{~m}$. The second MG1 peak, at a depth of $2.8 \mathrm{~m}$, reached an abundance of $9.8 \times 10^{6}$ copies per gram of sediment. Thus, abundances of MG1 rRNA genes increased by two orders of magnitude from $1.7 \mathrm{~m}$ to $2.8 \mathrm{~m}$, whereas 
the abundance of total archaeal 16S rRNA genes increased only one order of magnitude between these depths.

\section{Archaeal amoA gene distributions}

The results from all four qPCR primer sets targeting archaeal amoA genes (Table 1) provided reproducible (self-consistent) data under the recommended amplification conditions. Moreover, all four primer sets yield the same range of abundances for the amoA gene throughout the upper half of the sediment core (Figure 1C). However, below $2.8 \mathrm{~m}$ the Treusch et al. (Treusch et al. 2005) primer set yielded archaeal amoA gene abundances that were approximately 1 order of magnitude lower than the other three primer sets (Figure 1C). In addition, the Francis et al. (Francis et al. 2005) primers yield a low (order of magnitude) estimate compared to the Mincer et al. (Mincer et al. 2007) and Wuchter et al. (Wuchter et al. 2006) primers at a depth of $2.7 \mathrm{~m}$. However, given the general consistency between the Wuchter et al. (Wuchter et al. 2006), Mincer et al. (Mincer et al. 2007), and Francis et al. (Francis et al. 2005) primer sets throughout the sediment core (Figure 1C), we have chosen to present our amoA gene data as obtained by the Francis et al. (Francis et al. 2005) primer set for the remainder of the discussion.

Archaeal amoA genes occurred in high abundance in the surface and at $2.8 \mathrm{~m}$ in the core, with approximately $8.3 \times 10^{6}$ and $1.1 \times 10^{7} \mathrm{amo} A$ copies per gram of sediment respectively (Figure 1D). The archaeal amoA gene abundance remained low until $2 \mathrm{~m}$, then increased to a second maximum of $1.1 \times 10^{7}$ copies per gram sediment at $2.8 \mathrm{~m}$ and decreased slightly toward the bottom of the sediment core. Each primer set confirmed 
these main features, with an approximately 100 -fold decrease in amo $A$ gene abundance between the surface and $1.5 \mathrm{~m}$ and a secondary peak at $2.8 \mathrm{~m}$ (Figure 1C). The archaeal amoA abundance was not strongly correlated with any of the environmental parameters measured. The best observed correlation was a negative correlation between archaeal amoA gene abundance and redox potential (Figure 2, $\mathrm{r}^{2}=0.43$ ).

Normalizing the archaeal amoA gene abundance to archaeal 16S rRNA gene abundance revealed that the AOA component accounted for a maximum of approximately $1 \%$ of the total archaeal population in the upper $0.5 \mathrm{~m}$, assuming one copy of amoA per AOA genome (Mincer et al. 2007). However, comparison of archaeal amoA gene abundance to MG1 16S rRNA gene abundance showed a gene ratio close to 1 throughout most of the sediment column, abruptly climbing to 2 at $3.8 \mathrm{~m}$. Like $a m o A$, a correlation was observed between MG1 16S rRNA gene abundance and redox potential (Figure 2, $r^{2}=0.47$ ).

\section{Bacterial amoA gene distribution}

Bacterial amoA abundance was low throughout the sediment column, with approximately $3.3 \times 10^{4}$ copies per gram of sediment at the surface sediments, increasing to $6.0 \times 10^{5}$ copies per gram of sediment at $2 \mathrm{~m}$ (Figure 1D). Below $2 \mathrm{~m}$, bacterial amo $A$ dropped to $1.3 \times 10^{3}$ copies per gram of sediment. Between a depth of 1.2 and $2 \mathrm{~m}$, the bacterial amoA gene reached a maximum abundance $\left(6.0 \times 10^{5}\right.$ copies per gram of sediment), accounting for up to $80 \%$ of the total amoA gene pool at $2 \mathrm{~m}$. However, except 
for this interval, the bacterial amoA gene was 1-2 orders of magnitude less abundant than the archaeal version.

\section{Archaeal 16S rRNA gene diversity}

The archaeal 16S rRNA genes recovered from the aquifer sediments belonged to both the Euryarchaeota and Crenarchaeota subdivisions, with roughly equal contributions from the Euryarchaeota ( 36 out of 84, 43\%), and the Crenarchaeota (48 out of 84, 57\%), for which MG1 Crenarchaeota accounted for the majority of the sequences (Figure 4). Therefore, in contrast to the qPCR results, which showed MG1 abundance to be approximately $1 \%$ of total archaea, the archaeal clone libraries were approximately $50 \%$ MG1. As discussed below, this discrepancy may be the result of biases in PCR amplification and/or cloning. The Crenarchaeota sequences were recovered from all depths in the aquifer, and they were most closely related to Cenarchaeales-like sequences (which includes Nitrosopumilus maritimus), although sequences were also recovered from pSL12-like organisms (4 out of 48, 8\%). Both MG1 and PSL12 clades have been implicated in nitrification (Konneke et al. 2005; Hallam et al. 2006; Mincer et al. 2007). A third group of organisms related to SAGMA-like (South African Gold Mine Archaea) subgroup of the Crenarchaeota were also recovered throughout the aquifer ( 7 of 48 , $15 \%)$. It is unknown whether these organism harbor amoA genes. Related $16 \mathrm{~S}$ rRNA genes have been found in many environments including surface marine waters, Antarctic bathypelagic and other deep marine sediments (Gillan and Danis 2007), uranium mine tailings (Takai et al. 2001), and agricultural soils (McInerney 1997). 


\section{Archaeal amoA Clone Libraries}

The archaeal amoA clone libraries (consisting of 343 clones total, 92 from $1 \mathrm{~m}, 96$ from $2 \mathrm{~m}, 86$ from $3 \mathrm{~m}$ and 69 from $4 \mathrm{~m}$ ) from the aquifer sediments revealed two distinct communities within the system. The first community was mostly found in the upper two meters of the aquifer sediments and a second community between two and four meters within the sediments. The amoA genes recovered from the upper two meters clustered primarily with Water Column-like sequences within the archaeal amo $A$ phylogeny (Figure 5) (Francis et al. 2005; Beman and Francis 2006). This group includes sequences from open ocean, coastal waters and estuarine systems (Beman and Francis 2006; Mosier and Francis 2008). The sequences from Waquoit Bay were most similar to sequences from the low-salinity sediments of North San Francisco Bay $(21,39)$. Below two meters the recovered amo $A$ genes revealed a different community. The sequences obtained from this deeper community were distributed within a cluster of archaeal amoA genes obtained from sediment, soil and groundwater (Hansel et al. 2008; van der Wielen et al. 2009).

\section{Discussion}

Many studies concerning nitrogen biogeochemistry in coastal groundwater focus on the role of denitrification as a mechanism of nitrogen loss (LaMontagne et al. 2002; Addy et al. 2005) with less consideration for how this process fits in the broader context of nitrogen transformations comprising the nitrogen cycle. For example, denitrification requires a source of nitrate, which can be transported into the system or produced locally. 
Indeed, a great deal of nitrogen is thought to be lost through coupled nitrificationdenitrification in estuarine systems. A few previous studies have used modeled and measured chemical fluxes to quantify the fluxes of nitrogen within the Waquoit Bay subterranean estuary (Kroeger and Charette 2008; Spiteri et al. 2008). Both approaches have suggested that nitrification may occur in both at the surface and deep salt transition zone, where both ammonia and oxygen are present. Here we have used molecular techniques to describe the microbial communities harbored by the aquifer sediments and examine whether these communities contain the genetic potential for nitrification. We also report the congruity of the major published primer sets for the archaeal amo $A$ gene. Furthermore, we examine the relative contribution of AOA and AOB to the potential nitrifying community, focusing on the potential changes in their abundance and community structure in the different zones of the Waquoit Bay subterranean estuary.

\section{S rRNA gene abundance}

The observed archaeal 16S rRNA gene abundance falls within the range of values reported for near-surface marine sediments (Schippers and Neretin 2006). In this subterranean estuary, the increase in the archaeal 16S rRNA gene abundance at depth corresponds to a region that is dynamic and is likely exposed to both saline and fresh pore waters over the course of the annual hydrologic and tidal cycles. As the intruding saltwater wedge advances shoreward during the drier seasons (lower hydraulic head), this water carries with it a greater ionic strength, lower oxygen levels, and higher concentrations of ammonia. Interestingly, the bacterial 16S rRNA gene does not show 
this same increase at depth. Although it is tempting to speculate about which environmental factor(s) may contribute to the observed increase in archaea at depth, $16 \mathrm{~S}$ rRNA gene abundance does not show a strong correlation to any of the collected environmental data $\left(\mathrm{NO}_{3}{ }^{-}\right.$, salinity, $\mathrm{O}_{2}$, etc.).

In contrast to total archaeal $16 \mathrm{~S}$ rRNA abundance, the abundance of the MG1 $16 \mathrm{~S}$ rRNA genes did show local maxima in the near surface, as well as at depth in the sediment profile (Figure 1B). These peaks are coincident with local maxima in the abundance of archaeal amoA genes. Moreover, the relative abundance of MG1 16S rRNA gene copies was very similar to the archaeal amoA gene copies throughout the core, indicating approximately 1 copy of amo $A$ per $16 \mathrm{~S}$ rRNA gene at all but the deepest site, where the ratio approached 2. This result is similar to that obtained by Beman et al. (Beman and Francis 2006) in a Mexican estuary, Wuchter et al. (Wuchter et al. 2006) in the North Sea, and by Mincer et al. (Mincer et al. 2007) in the north Pacific subtropical gyre (save for the depth interval between 100 and $300 \mathrm{~m}$ in the Pacific data set where pSL12-like organisms were suspected of contributing to the amoA gene pool). An amoA:16S rRNA gene ratio of 1 is also predicted from the available genomes of ammonia-oxidizing archaea (Nitrosopumilus maritimus SCMI and Cenarchaeum symbiosum A), which each containing one copy of the amoA and 16S rRNA genes per genome. 


\section{Archaeal 16S rRNA gene libraries}

In contrast to MG1 accounting for only $1 \%$ of the total archaeal $16 \mathrm{~S}$ rRNA genes by qPCR, MG1 sequences comprised more than half the sampled archaeal 16S rRNA clone library. These results could be due to PCR primer bias, cloning or library sampling bias and/or changes in amplification chemistries and efficiencies between the two PCR methods. At this point, we do not fully understand the reason(s) for this discrepancy.

The presence of Euryarchaeota in this environment is not unexpected; however, the high frequency of these sequences in the archaeal 16S rRNA clone libraries was surprising. The recovered Euryarchaeota sequences all fell within the Methanosarcinales clade, which contains anaerobic, methanogenic organisms. This is an interesting finding given the bulk of the sampled water is oxic and should inhibit methanogenesis. However, the confluence of the deep salt wedge and fresh groundwater plume may contain low enough levels of oxygen and to favor methanogenesis. The presence of these autotrophs is consistent with the low DOC concentrations typically encountered in this environment (Charette et al. 2005; Charette and Sholkovitz 2006; Bone et al. 2007). However, to our knowledge, neither the presence of methane nor the activity of methanogens have been examined in this aquifer.

\section{Archaeal amoA Gene Libraries}

The archaeal amo $A$ gene libraries from the aquifer sediments revealed two distinct communities within the system, a water column group and a soils/sediments group. In the Waquoit Bay groundwater system, the water column-like sequences were recovered 
exclusively from the upper two meters of the sediment column. Given the high abundance and subsurface peak of archaeal amo $A$ genes in this upper meter it is unlikely that these sequences originated from organisms simply trapped in the sediment column from tidal exchange with the bay. Moreover, the close similarity between our sequences and those recovered from low-salinity, low nutrient, estuarine sediments (Francis et al. 2005; Mosier and Francis 2008) suggests the possibility of a niche for this particular group of AOA. Below two meters, the phylogenetic affiliation of the recovered amoA genes shifted from water column-like to sediment, soil and groundwater-like sequences. The majority of the sequences recovered from the deeper section were most closely related to sequences recovered from groundwater treatment plants (van der Wielen et al. 2009) and terrestrial soils (Hansel et al. 2008).

Similar "niche separation" has been reported in other estuarine environments, with sequence types clustering geographically within a single estuary (Beman and Francis 2006). Unfortunately, there is still great uncertainty about the environmental conditions or physiological properties that may influence the distribution of different AOA clades (Erguder et al. 2009). The driving force behind this difference in communities is not evident given our (or other published) chemical data from Waquoit Bay. The difference in community composition may contribute to the mismatch in archaeal amoA abundance determined using different qPCR primer sets, and primer selection should be considered carefully in environmental studies. 


\section{Primer Sensitivity in amoA $q P C R$}

This work represents the first study to experimentally test congruity of the published primer sets for the archaeal amoA gene on environmental samples. Despite the different target regions and degeneracies of the primer sets, they yielded remarkably similar results in the upper 2 meters of the sediment column (Figure 1C). The main difference between the primer sets was observed in the deeper AOA communities, where the Treusch et al. (Treusch et al. 2005) primers underestimated abundance by 1 order of magnitude relative to the other primer sets (Figure 1C). The Treusch et al. (Treusch et al. 2005) primers were initially designed for use in a TaqMan assay using the amoA genes detected in a soil fosmid 54d9 (61) as well as the Sargasso Sea Whole Genome Shotgun (WGS) sequence (Treusch et al. 2005), and it should be noted that their use here involved direct application in a SYBR Green I assay, rather than the intended TaqMan assay. However, given the larger degree of degeneracy of these forward and reverse primers (six degeneracies in the forward primer and five degeneracies in the reverse primer) (Figure 3), we would have expected a broader target range for these primers relative to other sets rather than a more restricted target range. To examine the possibility that the Treusch et al. (Treusch et al. 2005) primers were missing a subset of the deep Waquoit Bay AOA community, these primers were checked in silico against sequences recovered in libraries constructed using the Francis et al. (2005) primers. The alignment showed that these primers matched only $5.7 \%$ of our recovered sequences ( 4 of 69 clones from $4 \mathrm{~m}$ ). Furthermore, matching the Treusch et al. (Treusch et al. 2005) primers to archaeal amoA reference sequences (14 of 318 sequences reported in Francis et al. (Francis et al. 2005)) 
and a survey of archaeal amoA genes from GenBank (132 of 3530 sequences from GenBank) also reveals that these primers match less than $4 \%$ of the sequences. Therefore, it is not surprising that this primer set returns a lower abundance of amo $A$ than data derived from the other amo $A$ gene primers. As a result of these findings, we have chosen to report our abundances as determined using the Francis et al. (Francis et al. 2005) primer set for the following discussion.

\section{Relative abundances of $A O B$ and $A O A$}

For many years, AOB were the primary organisms believed able to catalyze the nitrification processes that can ultimately, through coupled nitrification-denitrification, lead to nitrogen removal from the environment. Studies have shown AOB abundance (Stehr et al. 1995; Cebron et al. 2003) and nitrification rates (Rysgaard et al. 1999; Cebron et al. 2003) increasing in the freshwater end members of surficial estuaries compared with abundances and rates measured in the seawater end-members. However, these studies did not include AOA cell abundance, or their contributions to nitrification rates. Recent reports have examined spatial patterns in the distribution of the AOA and $\mathrm{AOB} a m o A$ genes in relation to ammonia and organic carbon concentrations, salinity fluctuations, and other chemical loads (Bernhard et al. 2005; Francis et al. 2005; Freitag et al. 2006; Mosier and Francis 2008; Bernhard et al. 2010). Relative changes in abundance between AOB and AOA have been found to be correlated with $\mathrm{C}: \mathrm{N}$ (Mosier and Francis 2008), salinity and oxygen (Beman and Francis 2006; Mosier and Francis 2008; Santoro et al. 2008), as well as trace metal availability (lead and nickel) (Caffrey et 
al. 2007; Mosier and Francis 2008). The recent report of potential mixotrophy in $C$. symbiosum (Hallam et al. 2006) and planktonic archaea (Ouverney and Fuhrman 2000; Ingalls et al. 2006) hint at the potential plasticity of the metabolic capabilities, which may allow AOA to survive in dynamic regions of the environment were DOC and mobilized ammonia may periodically be injected. Recent culture based studies have shown that the archaea are adapted to life in nutrient limited conditions. Nitrosopumilus maritimus SCM1 has been shown to have a high affinity for ammonium and a low substrate threshold of $10 \mathrm{nM} \mathrm{NH}_{3}$ or less (Martens-Habbena et al. 2009). The most dynamic conditions in the Waquoit Bay subterranean estuary are found in the upper and lower salt transition zones, which are periodically exposed to saline, low oxygen pore waters with elevated concentrations of ammonium, and in some cases DOC (Charette and Sholkovitz 2006; Bone et al. 2007). However, a clear consensus on the interactions between these environmental factors and AOA distributions has not been reached (Erguder et al. 2009).

In the Waquoit Bay aquifer system, archaeal amoA dominated the total amo $A$ gene pool, accounting for $>90 \%$ of total amoA at most depths in the core. Peaks in archaeal amoA distribution occurred in the surface meter and in the lower portion of the nitrate peak near the saltwater interface, while the bacterial amoA abundance peaked at a shallower depth within the fresh groundwater plume. In the present study, neither the raw nor relative abundance of sediment-associated AOA or AOB showed a strong correlation with any of the simultaneously measured pore water parameters $\left(\mathrm{O}_{2}\right.$, salinity, $\mathrm{NO}_{3}^{-}, \mathrm{NO}_{2}^{-}$, $\mathrm{NH}_{4}^{+}, \mathrm{pH}$, or redox potential). The best correlation was observed between archaeal amo $A$ and redox potential. However, fluctuations in pore water conditions (the depth of the 
deep salt-wedge, the presence of a reduced ammonium bearing plume in center of the groundwater plume and tidal pumping) have been observed or modeled at nearby sites (Charette et al. 2005; Kroeger and Charette 2008; Spiteri et al. 2008), and the distribution of sediment-associated microbes may reflect an average, rather than instantaneous, condition.

\section{Conclusions}

This study reports the diversity and distribution of bacterial and archaeal 16S rRNA and amoA genes within a subterranean estuary. We also report on the congruity of various published primer sets used for amplifying archaeal amoA genes. Closer inspection of the abundance and diversity of nitrifying organisms inhabiting the aquifer sediments, as defined by the amoA gene, indicated a community dominated by AOA rather than $\mathrm{AOB}$ at most depths, except between 1.2 and $2 \mathrm{~m}$ in the fresh groundwater plume. Sequencing the amo $A$ gene from the two peaks in archaeal abundance revealed that these represent two different populations. The shallow population contained amo $\mathrm{A}$ gene sequences within the Water Column A cluster, with the most closely related sequences originating from low salinity estuarine sediments. The deeper aquifer population is more closely related to amoA sequences recovered from soil and groundwater systems. This difference in community structure suggests an environmental factor (or combination of factors) may control the distribution of these populations within the aquifer. However, the measured environmental conditions in this study do not provide an adequate answer for this question. Further work, both in the environment and with 
cultured AOA, is needed to discover what environmental conditions favor different AOA and AOB populations and what other metabolic and biogeochemical functions AOA may bring to the environment.

\section{Acknowledgements}

Special thanks to Erin Banning, Matt McIlvin, Kevin Kroeger, Laura Erban and James Saenz for field and laboratory support. We would also like to acknowledge Paul Henderson for laboratory support. Helpful discussions and critiques from all members of the Casciotti lab, Sievert lab, Charette lab and three anonymous reviewers are gratefully appreciated. We are also grateful for the assistance of Chris Wiedman, Mary-Kay Fox and other at the Waquoit Bay National Estuarine Research Reserve. Funding was provided by WHOI's Coastal Ocean Institute to DRR and KLC, as well as funding from NSF/OCE project \#05-24994 to KLC. 
Table 1. Molecular Methods

\begin{tabular}{|c|c|c|c|c|c|}
\hline $\begin{array}{l}\text { Target } \\
\text { Gene }\end{array}$ & $\begin{array}{c}\text { Primer Names } \\
\text { And } \\
\text { Sequences } \\
\end{array}$ & Thermal Program & $\begin{array}{c}\text { qPCR } \\
\text { Efficiency }\end{array}$ & Positive Control & Reference \\
\hline $\begin{array}{l}\text { Bacterial } \\
16 S \text { rRNA } \\
\text { (sequencing } \\
\text { only) }\end{array}$ & $\begin{array}{l}\text { 8F (400nM)- } \\
\text { AGAGTTTGATCCTGGCTCAG } \\
\text { 1492R }(400 \mathrm{nM})- \\
\text { GGTTACCTTGTTACGACTT }\end{array}$ & $\begin{array}{l}94^{\circ} \mathrm{C} \text { for } 120 \mathrm{sec} . \\
30 \text { cycles of } \\
94^{\circ} \mathrm{C} \text { for } 30 \mathrm{sec} \\
47^{\circ} \mathrm{C} \text { for } 60 \mathrm{sec} \\
72^{\circ} \mathrm{C} \text { for } 60 \mathrm{sec} \\
\text { Final extension of } \\
72^{\circ} \mathrm{C} \text { for } 600 \mathrm{sec}\end{array}$ & & $\begin{array}{l}\text { Escherichia coli, } \\
\text { Pseudomonas } \\
\text { stutzeri }\end{array}$ & \\
\hline $\begin{array}{l}\text { Bacterial } \\
16 \mathrm{~S} \text { rRNA }\end{array}$ & $\begin{array}{l}\text { Bac1369 (1000nM)- } \\
\text { CGGTGAATACGTTCYCGG } \\
\text { Prok1541 (1000nM)- } \\
\text { AAGGAGGTGATCCRGCCGCA }\end{array}$ & $\begin{array}{l}50^{\circ} \mathrm{C} \text { for } 120 \mathrm{sec} \\
94^{\circ} \mathrm{C} \text { for } 120 \mathrm{sec} \\
40 \text { cycles of } \\
94^{\circ} \mathrm{C} \text { for } 15 \mathrm{sec} \\
59^{\circ} \mathrm{C} \text { for } 60 \mathrm{sec}\end{array}$ & $88-90 \%$ & P. stutzeri & $\begin{array}{l}\text { (Suzuki et } \\
\text { al. 2000) }\end{array}$ \\
\hline $\begin{array}{l}\text { Archaeal } \\
\text { 16S rRNA } \\
\text { (sequencing } \\
\text { only) }\end{array}$ & $\begin{array}{l}\text { 21Fa (400nM)- } \\
\text { TTCCGGTTGATCCYGCCGGA } \\
\text { 1492R (400nM)- } \\
\text { GGTTACCTTGTTACGACTT }\end{array}$ & $\begin{array}{l}94^{\circ} \mathrm{C} \text { for } 120 \mathrm{sec} . \\
30 \mathrm{cycles} \text { of } \\
94^{\circ} \mathrm{C} \text { for } 30 \mathrm{sec} \\
47^{\circ} \mathrm{C} \text { for } 60 \mathrm{sec} \\
72^{\circ} \mathrm{C} \text { for } 60 \mathrm{sec} \\
\text { Final extension of } \\
72^{\circ} \mathrm{C} \text { for } 600 \mathrm{sec} \\
\end{array}$ & & \begin{tabular}{|l|} 
Ferroplama \\
acidarmonas
\end{tabular} & $\begin{array}{l}\text { Reysenbac } \\
\text { h et al. } \\
1992)\end{array}$ \\
\hline $\begin{array}{l}\text { Archaeal } \\
\text { 16S rRNA }\end{array}$ & $\begin{array}{l}\text { Arcmix1369F (1:1 mixture) } \\
\text { (500nM)- } \\
\text { CGGTGAATACGTCCCTGC and } \\
\text { CGGTGAATATGCCCCTGC } \\
\text { Prok1541 (1000nM)- } \\
\text { AAGGAGGTGATCCRGCCGCA }\end{array}$ & $\begin{array}{l}50^{\circ} \mathrm{C} \text { for } 120 \mathrm{sec} \\
94^{\circ} \mathrm{C} \text { for } 120 \mathrm{sec} \\
40 \mathrm{cycles} \text { of } \\
94^{\circ} \mathrm{C} \text { for } 15 \mathrm{sec} \\
59^{\circ} \mathrm{C} \text { for } 60 \mathrm{sec} \\
80^{\circ} \mathrm{C} \text { for } 15 \mathrm{sec} \\
\text { (read) }\end{array}$ & $98-105 \%$ & $\begin{array}{l}\text { F. acidarmonas, } N . \\
\text { maritimus }\end{array}$ & $\begin{array}{l}\text { (Suzuki et } \\
\text { al. 2000) }\end{array}$ \\
\hline $\begin{array}{l}\text { MG1 } \\
\text { Crenarchaeota }\end{array}$ & $\begin{array}{l}\text { GI-751F (500nM)- } \\
\text { GTCTACCAGAACAYGTTC } \\
\text { GI_956R (500nM)- } \\
\text { HGGCGTTGACTCCAATG }\end{array}$ & $\begin{array}{l}95^{\circ} \mathrm{C} \text { for } 900 \mathrm{sec} \\
50 \mathrm{cycles} \text { of } \\
94^{\circ} \mathrm{C} \text { for } 15 \mathrm{sec} \\
58^{\circ} \mathrm{C} \text { for } 30 \mathrm{sec} \\
72^{\circ} \mathrm{C} \text { for } 30 \mathrm{sec} \\
80^{\circ} \mathrm{C} \text { for } 15 \mathrm{sec} \\
(\mathrm{read})\end{array}$ & $93-95 \%$ & $\begin{array}{l}\text { N. maritimus, } \\
\text { environmental clone }\end{array}$ & $\begin{array}{l}\text { (Mincer et } \\
\text { al. 2007) }\end{array}$ \\
\hline $\begin{array}{l}\text { Francis et al. } \\
\text { amoA } \\
\text { (sequencing } \\
\text { and qPCR) }\end{array}$ & $\begin{array}{l}\text { amoAF (500nM)- } \\
\text { STAATGGTCTGGCTTAGACG } \\
\text { amoAR (500nM)- } \\
\text { GCGGCCATCCATCTGTATGT }\end{array}$ & $\begin{array}{l}95^{\circ} \mathrm{C} \text { for } 300 \\
30 \mathrm{cycles} \text { of } \\
94^{\circ} \mathrm{C} \text { for } 30 \mathrm{sec} \\
53^{\circ} \mathrm{C} \text { for } 60 \mathrm{sec} \\
72^{\circ} \mathrm{C} \text { for } 60 \mathrm{sec} \\
80^{\circ} \mathrm{C} \text { for } 15 \mathrm{sec} \\
\text { (read) }\end{array}$ & $93-95 \%$ & $\begin{array}{l}\text { N. maritimus, } \\
\text { environmental clone }\end{array}$ & $\begin{array}{l}\text { (Francis et } \\
\text { al. 2005) }\end{array}$ \\
\hline $\begin{array}{l}\text { Wuchter et al. } \\
\text { amoA }\end{array}$ & $\begin{array}{l}\text { archamoAF (500nM)- } \\
\text { CTGAYTGGGCYTGGACATC } \\
\text { archamoR (500nM)- } \\
\text { TTCTTCTTTGTTGCCAGTA }\end{array}$ & $\begin{array}{l}95^{\circ} \mathrm{C} \text { for } 300 \mathrm{sec} \\
35 \mathrm{cycles} \text { of } \\
94^{\circ} \mathrm{C} \text { for } 30 \mathrm{sec} \\
61.5^{\circ} \mathrm{C} \text { for } 40 \mathrm{sec}\end{array}$ & $95-96 \%$ & $\begin{array}{l}\text { N. maritimus, } \\
\text { environmental clone }\end{array}$ & $\begin{array}{l}\text { (Wuchter et } \\
\text { al. 2006) }\end{array}$ \\
\hline
\end{tabular}




\begin{tabular}{|c|c|c|c|c|c|}
\hline $\begin{array}{l}\text { Target } \\
\text { Gene }\end{array}$ & $\begin{array}{c}\text { Primer Names } \\
\text { And } \\
\text { Sequences } \\
\end{array}$ & Thermal Program & \begin{tabular}{|c|} 
qPCR \\
Efficiency
\end{tabular} & Positive Control & Reference \\
\hline & & $\begin{array}{l}72^{\circ} \mathrm{C} \text { for } 40 \mathrm{sec} \\
80^{\circ} \mathrm{C} \text { for } 15 \mathrm{sec} \\
\text { (read) }\end{array}$ & & & \\
\hline $\begin{array}{l}\text { Mincer et al. } \\
\text { amoA }\end{array}$ & $\begin{array}{l}\text { crenamoAmodF (500nM)- } \\
\text { TGGCTAAGACGMTGTA } \\
\text { crenamoA-Q-F (500nM)- } \\
\text { GCARGTMGGWAARTTCTAYAA } \\
\text { crenamoAmodR (500nM)- } \\
\text { AAGCGGCCATCCATCTGTA }\end{array}$ & $\begin{array}{l}95^{\circ} \mathrm{C} \text { for } 900 \mathrm{sec} \\
50 \text { cycles of } \\
94^{\circ} \mathrm{C} \text { for } 15 \mathrm{sec} \\
52^{\circ} \mathrm{C} \text { for } 30 \mathrm{sec} \\
72^{\circ} \mathrm{C} \text { for } 30 \mathrm{sec} \\
80^{\circ} \mathrm{C} \text { for } 15 \mathrm{sec} \\
\text { (read) }\end{array}$ & $95-96 \%$ & $\begin{array}{l}\text { N. maritimus, } \\
\text { environmental clone }\end{array}$ & $\begin{array}{l}\text { (Mincer et } \\
\text { al. 2007) }\end{array}$ \\
\hline $\begin{array}{l}\text { Treusch et al. } \\
\text { amoA }\end{array}$ & $\begin{array}{l}\text { Amo196F (1000nM)- } \\
\text { GGWGTKCCRGGRACWGCMAC } \\
\text { Amo277R (1000nM)- } \\
\text { CRATGAAGTCRTAHGGRTADC }\end{array}$ & $\begin{array}{l}95^{\circ} \mathrm{C} \text { for } 150 \mathrm{sec} \\
45 \mathrm{cycles} \text { of } \\
95^{\circ} \mathrm{C} \text { for } 15 \mathrm{sec} \\
50^{\circ} \mathrm{C} \text { for } 40 \mathrm{sec} \\
80^{\circ} \mathrm{C} \text { for } 15 \mathrm{sec} \\
\text { (read) }\end{array}$ & $90-91 \%$ & $\begin{array}{l}\text { N. maritimus, } \\
\text { Environmental } \\
\text { clone }\end{array}$ & $\begin{array}{l}\text { (Treusch et } \\
\text { al. 2005) }\end{array}$ \\
\hline $\begin{array}{l}\text { Bacterial } \\
\text { amoA }\end{array}$ & $\begin{array}{l}\text { amo189F (300nM)- } \\
\text { GGHGACTGGGAYTTCTGG } \\
\text { amoA2-R' (900nM)- } \\
\text { CCTCKGSAAAGCCTTCTTC }\end{array}$ & $\begin{array}{l}50^{\circ} \mathrm{C} \text { for } 120 \mathrm{sec} \\
95^{\circ} \mathrm{C} \text { for } 600 \mathrm{sec} \\
40 \mathrm{cycles} \text { of } \\
95^{\circ} \mathrm{C} \text { for } 45 \mathrm{sec} \\
55^{\circ} \mathrm{C} \text { for } 60 \mathrm{sec} \\
72^{\circ} \mathrm{C} \text { for } 45 \mathrm{sec} \\
80^{\circ} \mathrm{C} \text { for } 15 \mathrm{sec} \\
(\mathrm{read})\end{array}$ & $96-97 \%$ & Nitrosomonas sp. & $\begin{array}{l}\text { (Okano et } \\
\text { al. 2004) }\end{array}$ \\
\hline
\end{tabular}



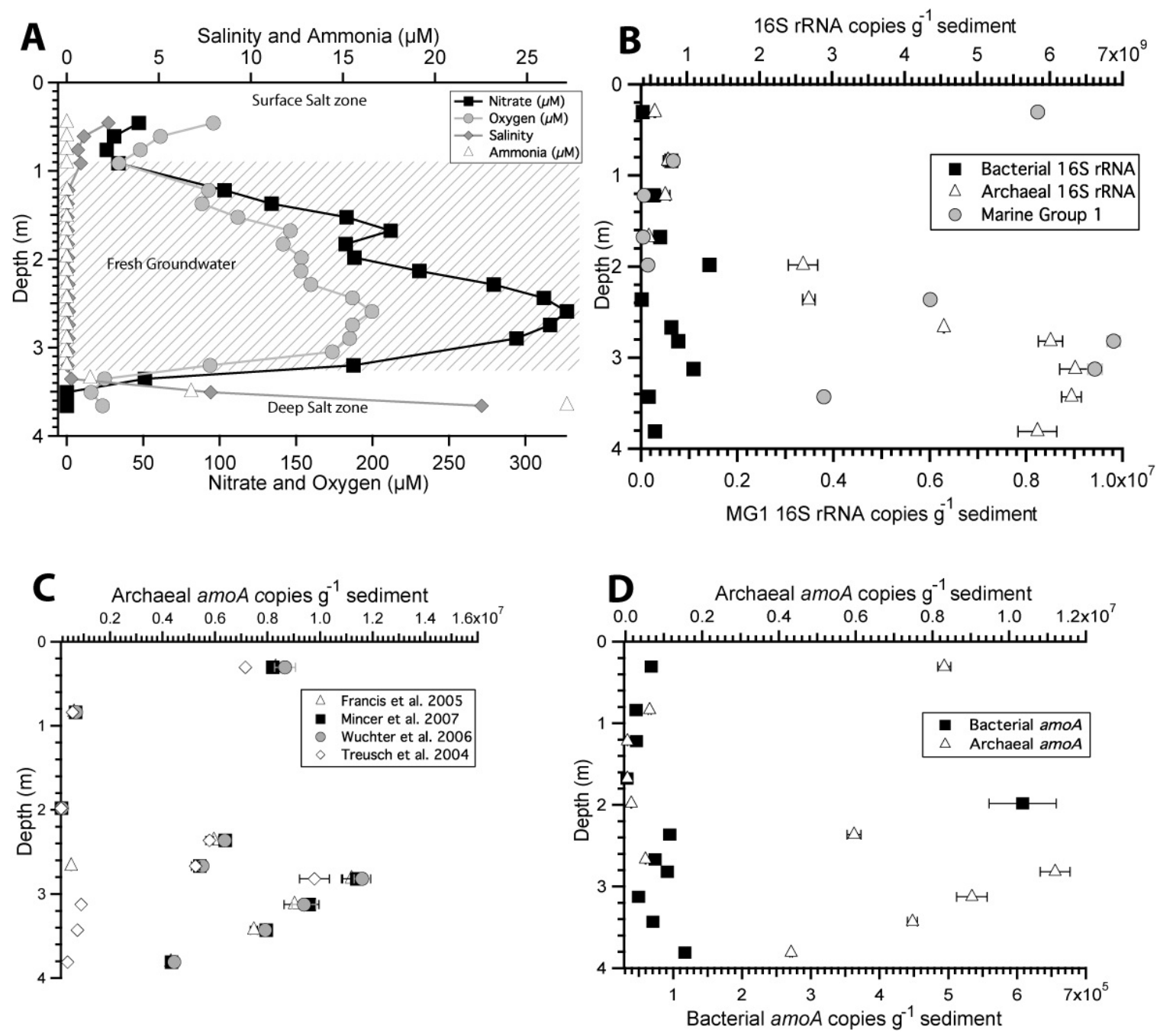

Figure 1. Pore water chemistry at study site. A) Salinity, nutrients $\left(\mathrm{NO}_{3}{ }^{-}\right.$and $\left.\mathrm{NH}_{4}{ }^{+}\right)$, and oxygen concentrations in the sediment pore water at the time of coring. The aquifer contains three distinct parcels of water: i) a saltwater surface zone (to about $1 \mathrm{~m}$ ), with low oxygen and nitrate levels, ii) a persistent fresh groundwater plume that carries elevated oxygen and nitrate concentrations, and iii) a deep anoxic salt wedge, which introduces ammonia in to the system. B) Depth distribution of total bacterial, archaeal and Marine Group I (MG1) archaeal 16S rRNA gene abundance. C) Primer-specific abundance of archaeal amo $A$ genes using the four published primer sets (Table 1). D) Depth distribution of bacterial and archaeal amoA abundance relative to MG1 16S rDNA abundance. 


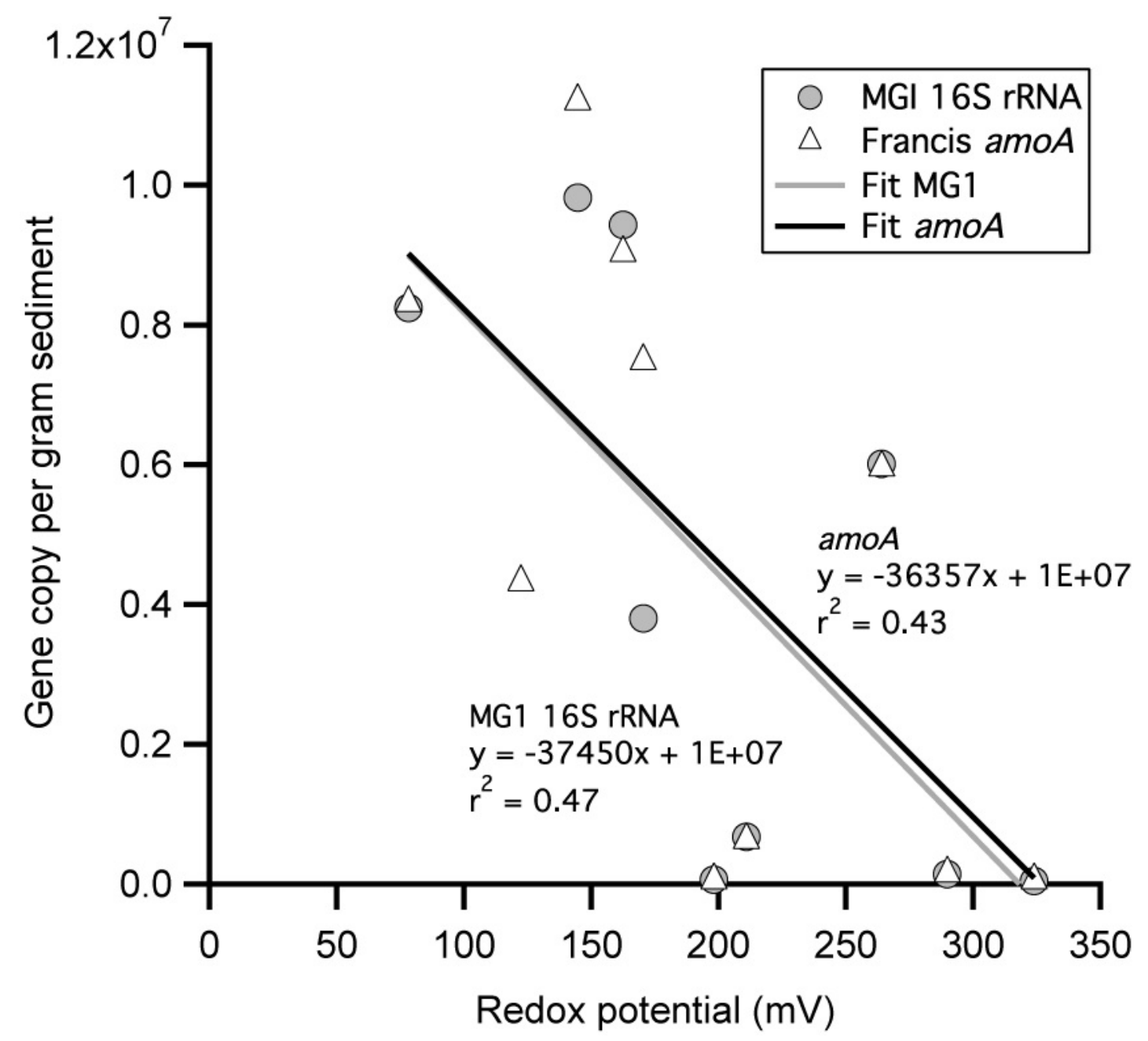

Figure 2. The abundance of MG1 $16 \mathrm{~S}$ rRNA and archaeal amo $A$ genes are weakly correlated with redox potential. No other measured environmental parameter was strongly correlated with the distribution of these genes. 


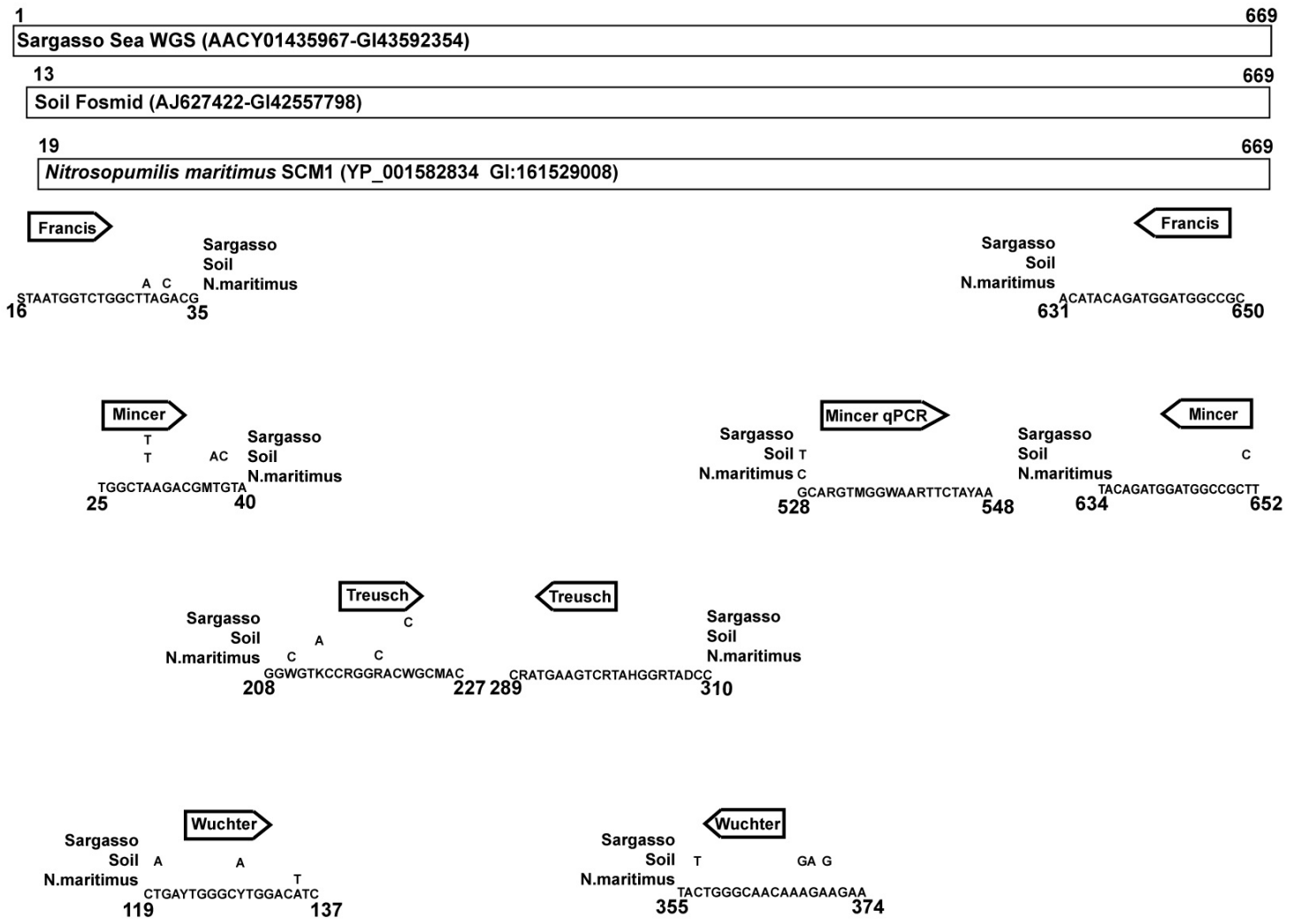

Figure 3. Alignment of each of the primer pairs used in the study to the reference sequences: Sargasso Sea WGS (Venter et al. 2004), Soil fosmid 54d9 (Treusch et al. 2005), and N. maritimus genome (gene 1500) (Konneke et al. 2005). Numbers beneath primer sequence represent alignment position relative to Sargasso Sea sequence. Mismatches to each of the three reference sequences are depicted above primer sequence. 


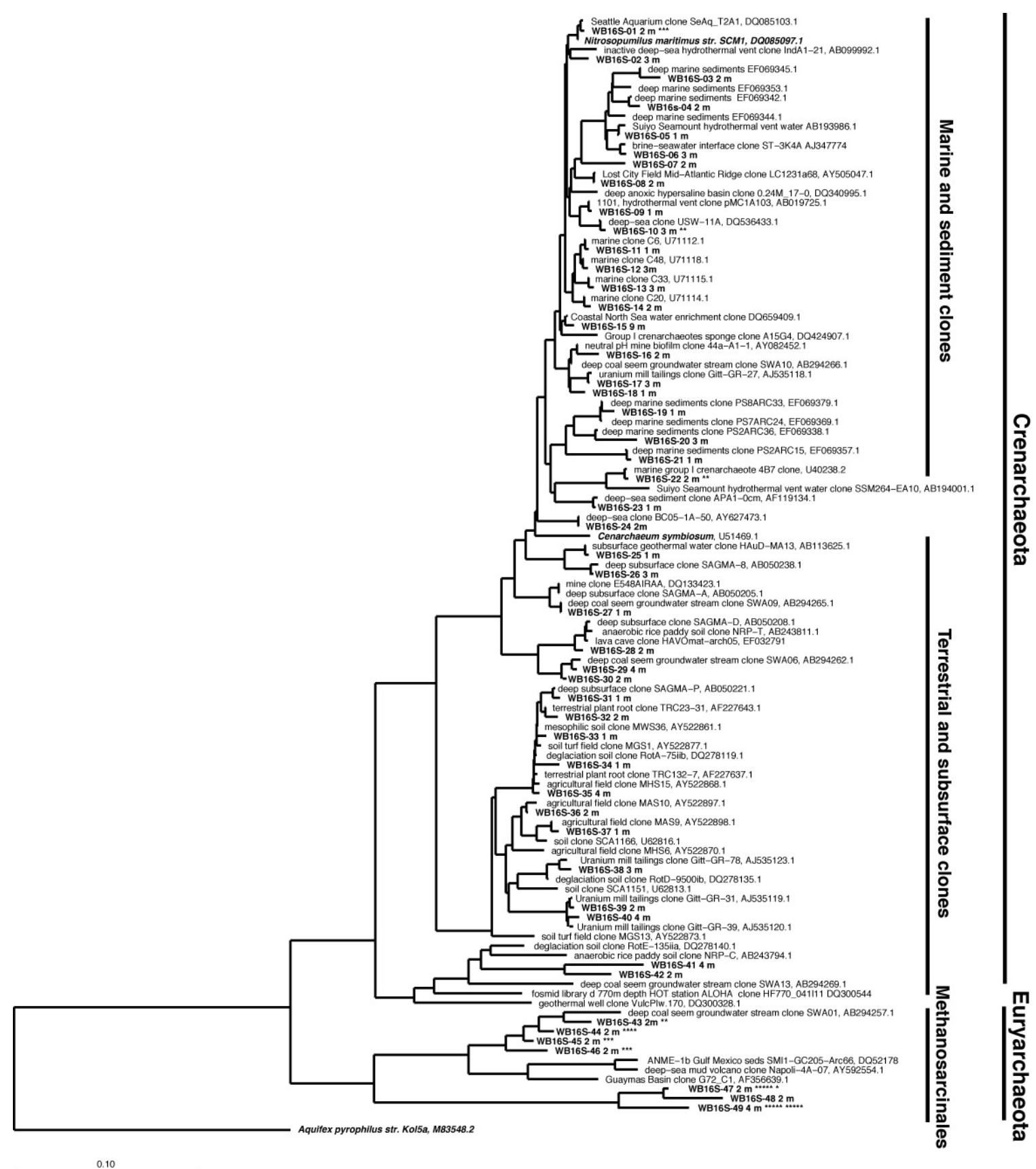

Figure 4. Phylogenetic tree, based on 1309 bp, of the archaeal 16S rRNA gene. Type strains are represented with bold and italicized font. Sequences recovered from this study are in bold. Sequences that were repeatedly recovered are marked with *. ARB neighbor joining methods, with Jukes-Cantor corrections, were used for tree construction. 

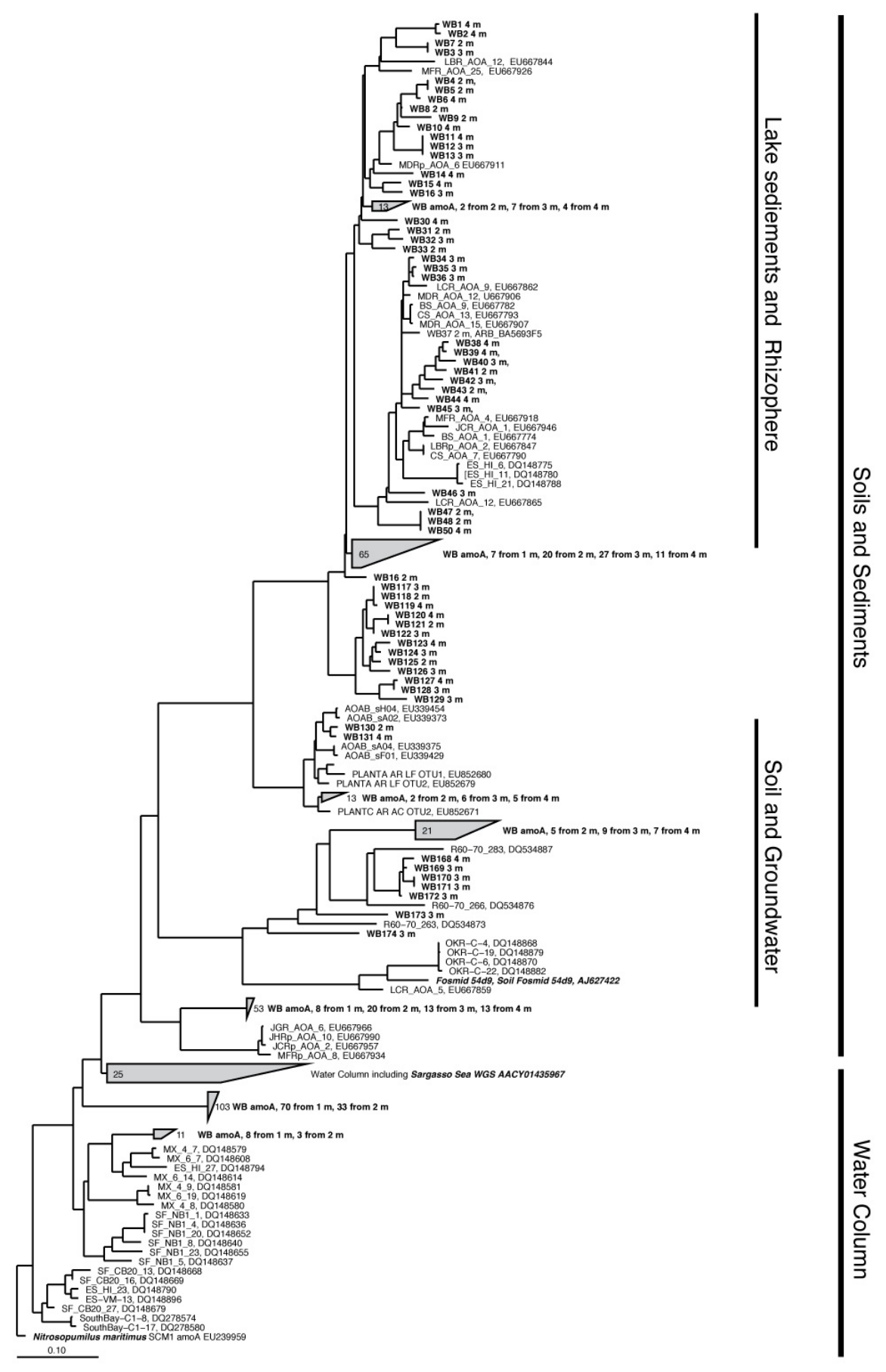
Figure 5. Phylogenetic tree based on $456 \mathrm{bp}$ of unambiguous amo $A$ nucleotide sequence. ARB neighbor joining methods, with Jukes-Cantor corrections, were used for tree construction. Clone libraries were constructed at six depths within the aquifer using the Francis et al. (Francis et al. 2005) primer pair. Recovered sequences fall within two major grouping of the archaeal amoA tree. Sequences from above a depth of $2 \mathrm{~m}$ in the aquifer are generally most similar to low salinity water column and estuary sequences with closest relatives recovered from the northern section of San Francisco Bay. Sequences from $2 \mathrm{~m}$ and below are more closely related to sequences recovered from freshwater sediments, rhizosphere, groundwater and terrestrial soils. Numbers within the wedges represent the number of sequences included in that branch. 


\section{References}

Addy, K., A. Gold, B. Nowicki, J. McKenna, M. Stolt and P. Groffman (2005).

"Denitrification capacity in a subterranean estuary below a Rhode Island fringing salt marsh." Estuaries and Coasts 28(6): 896-908.

Beman, J. M. and C. A. Francis (2006). "Diversity of ammonia-oxidizing archaea and bacteria in the sediments of a hypernutrified subtropical estuary: Bahia del Tobari, Mexico." Appl. Environ. Microbiol. 72(12): 7767-7777.

Benson, D. A., I. Karsch-Mizrachi, D. J. Lipman, J. Ostell, B. A. Rapp and D. L. Wheeler (2000). "GenBank." Nucleic Acids Res 28(1): 15-8.

Bernhard, A., T. Donn, A. Giblin and D. Stahl (2005). "Loss of diversity of ammoniaoxidizing bacteria correlates with increasing salinity in an estuary system." Environmental Microbiology 7(9): 1289-1297.

Bernhard, A. E., Z. C. Landry, A. Blevins, J. R. de la Torre, A. E. Giblin and D. A. Stahl (2010). "Abundance of Ammonia-Oxidizing Archaea and Bacteria along an Estuarine Salinity Gradient in Relation to Potential Nitrification Rates." Appl. Environ. Microbiol. 76(4): 1285-1289.

Bone, S., M. Charette, C. Lamborg and M. Gonneea (2007). "Has submarine groundwater discharge been overlooked as a source of mercury to coastal waters?" Environmental Science \& Technology 41(9): 3090-3095.

Bothe, H., G. Jost, M. Schloter, B. B. Ward and K. P. Witzel (2000). "Molecular analysis of ammonia oxidation and denitrification in natural environments." FEMS Microbiology Reviews 24(5): 673-690.

Caffrey, J. M., N. Bano, K. Kalanetra and J. T. Hollibaugh (2007). "Ammonia oxidation and ammonia-oxidizing bacteria and archaea from estuaries with differing histories of hypoxia." ISME Journal 1(7): 660-662.

Cebron, A., T. Berthe and J. Garnier (2003). "Nitrification and nitrifying bacteria in the lower Seine River and estuary (France)." Applied and Environmental Microbiology 69(12): 7091-7100.

Charette, M. and E. Sholkovitz (2002). "Oxidative precipitation of groundwater-derived ferrous iron in the subterranean estuary of a coastal bay." Geophysical Research Letters 29(10): 1444.

Charette, M. A., K. O. Buesseler and J. E. Andrews (2001). "Utility of radium isotopes for evaluating the input and transport of groundwater-derived nitrogen to a Cape Cod estuary." Limnology and Oceanography 46(2): 465-470.

Charette, M. A. and E. R. Sholkovitz (2006). "Trace element cycling in a subterranean estuary: Part 2. Geochemistry of the pore water." Geochimica et Cosmochimica Acta 70(4): 811.

Charette, M. A., E. R. Sholkovitz and C. M. Hansel (2005). "Trace element cycling in a subterranean estuary: Part 1. Geochemistry of the permeable sediments." Geochimica et Cosmochimica Acta 69(8): 2095.

Chou, H.-H. and M. H. Holmes (2001). "DNA sequence quality trimming and vector removal." Bioinformatics 17(12): 1093-1104. 
Cox, R. D. (1980). "Determination of nitrate and nitrite at the parts per billion level by chemiluminescence." Analytical Chemistry 52(2): 332-335.

Drummond, A., B. Ashton, M. Cheung, J. Heled, M. Kearse, R. Moir, S. Stones-Havas, T. Thierer and A. Wilson (2009). Geneious v4.6, Available from http://www.geneious.com/.

Edwards, K. J., P. L. Bond and J. F. Banfield (2000). "Characteristics of attachment and growth of Thiobacillus caldus on sulfide minerals: A chemotactic response to sulfur minerals." Environmental Microbiology 2: 324-332.

Erguder, T. H., N. Boon, L. Wittebolle, M. Marzorati and W. Verstraete (2009). "Environmental factors shaping the ecological niches of ammonia-oxidizing archaea." FEMS Microbiology Reviews 33(5): 855-869.

Ewing, B. and P. Green (1998). Base-calling of automated sequencer traces using Phred. II. Error probabilities, Cold Spring Harbor Lab. 8: 186-194.

Ewing, B., L. Hillier, M. Wendl and P. Green (1998). Base-calling of automated sequencer traces using Phred. I. Accuracy assessment, Cold Spring Harbor Lab. 8: $175-185$.

Francis, C. A., K. J. Roberts, J. M. Beman, A. E. Santoro and B. B. Oakley (2005). "Ubiquity and diversity of ammonia-oxidizing archaea in water columns and sediments of the ocean." PNAS 102(41): 14683-14688.

Freitag, T., L. Chang and J. Prosser (2006). "Changes in the community structure and activity of betaproteobacterial ammonia-oxidizing sediment bacteria along a freshwater-marine gradient." Environmental Microbiology 8(4): 684-696.

Garside, C. (1982). "A chemiluminescent technique for the determination of nanomolar concentrations of nitrate and nitrite in seawater." Marine Chemistry 11(2): 159167.

Garside, C. (1985). "The vertical distribution of nitrate in open ocean surface water." Deep Sea Research Part A. Oceanographic Research Papers 32(6): 723-732.

Gillan, D. and B. Danis (2007). "The archaebacterial communities in Antarctic bathypelagic sediments." Deep-Sea Research Part II 54(16-17): 1682-1690.

Hallam, S. J., T. J. Mincer, C. Schleper, C. M. Preston, K. Roberts, P. M. Richardson and E. F. DeLong (2006). "Pathways of carbon assimilation and ammonia oxidation suggested by environmental genomic analyses of marine crenarchaeota." PLoS Biology 4(4): e95.

Hansel, C. M., S. Fendorf, P. M. Jardine and C. A. Francis (2008). "Changes in bacterial and archaeal community structure and functional diversity along a geochemically variable soil profile." Appl. Environ. Microbiol. 74(5): 1620-1633.

Ingalls, A., S. Shah, R. Hansman, L. Aluwihare, G. Santos, E. Druffel and A. Pearson (2006). "Quantifying archaeal community autotrophy in the mesopelagic ocean using natural radiocarbon." Proceedings of the National Academy of Sciences 103(17): 6442-6447.

Konneke, M., A. E. Bernhard, J. R. de la Torre, C. B. Walker, J. B. Waterbury and D. A. Stahl (2005). "Isolation of an autotrophic ammonia-oxidizing marine archaeon." Nature 437(7058): 543. 
Kroeger, K. D. and M. A. Charette (2008). "Submarine groundwater discharge: nitrogen biogeochemistry of the discharge zone." Limnol. Oceanogr 53(3): 1025-1039.

LaMontagne, M., V. Astorga, A. Giblin and I. Valiela (2002). "Denitrification and the stoichiometry of nutrient regeneration in Waquoit Bay, Massachusetts." Estuaries and Coasts 25(2): 272-281.

Leininger, S., T. Urich, M. Schloter, L. Schwark, J. Qi, G. W. Nicol, J. I. Prosser, S. C. Schuster and C. Schleper (2006). "Archaea predominate among ammoniaoxidizing prokaryotes in soils." Nature 442(7104): 806.

Ludwig, W., O. Strunk, R. Westram, L. Richter, H. Meier, A. Buchner, T. Lai, S. Steppi, G. Jobb, W. Förster, I. Brettske, I. Gerber, A. Ginhart, O. Gross, S. Grumann, S. Hermann, R. Jost, A. König, T. Liss, R. Lüßmann, M. May, B. Nonhoff, B. Reichel, R. Strehlow, A. Stamatakis, N. Stuckmann, A. Vilbig, M. Lenke, T. Ludwig, A. Bode and K.-H. Schleifer (2004). "ARB: a software environment for sequence data." Nucleic Acids Res 32(4): 1363-1371.

Martens-Habbena, W., P. M. Berube, H. Urakawa, J. R. de la Torre and D. A. Stahl (2009). "Ammonia oxidation kinetics determine niche separation of nitrifying Archaea and Bacteria." Nature 461(7266): 976-979.

McClelland, J. and I. Valiela (1998). "Linking nitrogen in estuarine producer to landderived sources." Limnology and Oceanography 43(4): 577-585.

McInerney, J. (1997). "Phylogenetic analysis of Group I marine archaeal rRNA sequences emphasizes the hidden diversity within the primary group Archaea." Proceedings of the Royal Society B: Biological Sciences 264(1388): 1663-1669.

Michael, H., J. Lubetsky and C. Harvey (2003). "Characterizing submarine groundwater discharge: A seepage meter study in Waquoit Bay, Massachusetts." Geophysical Research Letters 30(6): 1297.

Mincer, T. J., M. J. Church, L. T. Taylor, C. Preston, D. M. Karl and E. F. DeLong (2007). "Quantitative distribution of presumptive archaeal and bacterial nitrifiers in Monterey Bay and the North Pacific Subtropical Gyre." Environmental Microbiology 9(5): 1162-1175.

Moore, W. (2006). "The role of submarine groundwater discharge in coastal biogeochemistry." Journal of Geochemical Exploration 88(1-3): 389-393.

Mosier, A. C. and C. A. Francis (2008). "Relative abundance and diversity of ammoniaoxidizing archaea and bacteria in the San Francisco Bay estuary." Environmental Microbiology 10(11): 3002-3016.

Mulligan, A. E. and M. Charette (2006). "Intercomparison of submarine groundwater discharge estimates from a sandy unconfined aquifer." Journal of Hydrology 327(3): 411-425.

Okano, Y., K. R. Hristova, C. M. Leutenegger, L. E. Jackson, R. F. Denison, B. Gebreyesus, D. Lebauer and K. M. Scow (2004). "Application of real-time PCR to study effects of ammonium on population size of ammonia-oxidizing bacteria in soil." Appl. Environ. Microbiol. 70(2): 1008-1016.

Oldale, R. (1976). "Notes on the generalized geologic map of Cape Cod. ." $\underline{\text { U.S. }}$ Geological Survey Open-File Report 76-765. 
Ouverney, C. C. and J. A. Fuhrman (2000). "Marine Planktonic Archaea Take Up Amino Acids." Appl. Environ. Microbiol. 66(11): 4829-4833.

Pai, S.-C., C.-C. Yang and J. P. Riley (1990). "Formation kinetics of the pink azo dye in the determination of nitrite in natural waters." Analytica Chimica Acta 232: 345349.

Reysenbach, A., L. Giver, G. Wickham and N. Pace (1992). "Differential amplification of rRNA genes by polymerase chain reaction." Appl. Environ. Microbiol. 58(10): 3417-3418.

Rysgaard, S., P. Thastum, T. Dalsgaard, P. Christensen and N. Sloth (1999). "Effects of salinity on $\mathrm{NH} 4+$ adsorption capacity, nitrification, and denitrification in Danish estuarine sediments." Estuaries and Coasts 22(1): 21-30.

Santoro, A. E., C. A. Francis, N. R. de Sieyes and A. B. Boehm (2008). "Shifts in the relative abundance of ammonia-oxidizing bacteria and archaea across physicochemical gradients in a subterranean estuary." Environmental Microbiology 10(4): 1068-1079.

Schauss, K., A. Focks, S. Leininger, A. Kotzerke, H. Heuer, S. Thiele-Bruhn, S. Sharma, B.-M. Wilke, M. Matthies, K. Smalla, J. C. Munch, W. Amelung, M. Kaupenjohann, M. Schloter and C. Schleper (2009). "Dynamics and functional relevance of ammonia-oxidizing archaea in two agricultural soils." Environmental Microbiology 11(2): 446-456.

Schippers, A. and L. N. Neretin (2006). "Quantification of microbial communities in near-surface and deeply buried marine sediments on the Peru continental margin using real-time PCR." Environmental Microbiology 8(7): 1251-1260.

Sham, C. H., J. W. Brawley and M. A. Moritz (1995). "Quantifying septic nitrogen loadings to receiving waters: Waquoit Bay, Massachusetts." International Journal of Geographical Information Science 9(4): 463-473.

Solorzano, L. (1969). "Determination of Ammonia in Natural Waters by the Phenolhypochlorite Method." Limnology and Oceanography 14(5): 799-801.

Spiteri, C., C. Slomp, M. Charette, K. Tuncay and C. Meile (2008). "Flow and nutrient dynamics in a subterranean estuary (Waquoit Bay, MA, USA): field data and reactive transport modeling." Geochimica et Cosmochimica Acta 72(14): 33983412.

Stehr, G., B. Bottcher, P. Dittberner, G. Rath and H. Koops (1995). "The ammoniaoxidizing nitrifying population of the River Elbe estuary." FEMS Microbiology Ecology 17(3): 177-186.

Suzuki, M. T., L. T. Taylor and E. F. DeLong (2000). "Quantitative analysis of smallsubunit rRNA genes in mixed microbial populations via 5'-nuclease assays." Appl. Environ. Microbiol. 66(11): 4605-4614.

Takai, K., D. P. Moser, M. DeFlaun, T. C. Onstott and J. K. Fredrickson (2001). "Archaeal diversity in waters from deep South African gold mines." Appl. Environ. Microbiol. 67(12): 5750-5760.

Talbot, J. M., K. D. Kroeger, A. Rago, M. C. Allen and M. A. Charette (2003). "Nitrogen flux and speciation through the subterranean estuary of Waquoit Bay, Massachusetts." Biol Bull 205(2): 244-245. 
Testa, J. M., M. A. Charette, E. R. Sholkovitz, M. C. Allen, A. Rago and C. W. Herbold (2002). "Dissolved Iron Cycling in the Subterranean Estuary of a Coastal Bay: Waquoit Bay, Massachusetts." Biol Bull 203(2): 255-256.

Tomasky, G., J. Barak, I. Valiela, P. Behr, L. Soucy and K. Foreman (1999). "Nutrient limitation of phytoplankton growth in Waquoit Bay, Massachusetts, USA: a nutrient enrichment study." Aquatic Ecology 33(2): 147-155.

Treusch, A. H., S. Leininger, A. Kletzin, S. C. Schuster, H.-P. Klenk and C. Schleper (2005). "Novel genes for nitrite reductase and Amo-related proteins indicate a role of uncultivated mesophilic crenarchaeota in nitrogen cycling." Environmental Microbiology 7: 1985.

Valiela, I., J. Costa, K. Foreman, J. Teal, B. Howes and D. Aubrey (1990). "Transport of groundwater-borne nutrients from watersheds and their effects on coastal waters." Biogeochemistry 10: 177-197.

Valiela, I., K. Foreman, M. LaMontagne, D. Hersh, J. Costa, P. Peckol, B. DeMeoAndreson, C. D'Avanzo, M. Babione, C.-H. Sham, J. Brawley and K. Lajtha (1992). "Couplings of watersheds and coastal waters: Sources and consequences of nutrient enrichment in Waquoit Bay, Massachusetts." Estuaries 15(4): 443-457.

van der Wielen, P. W. J. J., S. Voost and D. van der Kooij (2009). "Ammonia-oxidizing bacteria and archaea in groundwater treatment and drinking water distribution systems." Appl. Environ. Microbiol. 75(14): 4687-4695.

Venter, J. C., K. Remington, J. F. Heidelberg, A. L. Halpern, D. Rusch, J. A. Eisen, D. Wu, I. Paulsen, K. E. Nelson, W. Nelson, D. E. Fouts, S. Levy, A. H. Knap, M. W. Lomas, K. Nealson, O. White, J. Peterson, J. Hoffman, R. Parsons, H. BadenTillson, C. Pfannkoch, Y.-H. Rogers and H. O. Smith (2004). "Environmental genome shotgun sequencing of the Sargasso Sea." Science 304(5667): 66-74.

Wuchter, C., B. Abbas, M. J. L. Coolen, L. Herfort, J. van Bleijswijk, P. Timmers, M. Strous, E. Teira, G. J. Herndl, J. J. Middelburg, S. Schouten and J. S. Sinninghe Damste (2006). "Archaeal nitrification in the ocean." PNAS 103(33): 1231712322. 


\title{
Chapter 3: Isotopic and molecular evidence for denitrification in an anthropogeneically altered coastal aquifer.
}

\author{
Daniel R. Rogers ${ }^{\dagger *}$, Karen L. Casciotti ${ }^{\dagger}$ \\ ${ }^{\dagger}$ Department of Marine Chemistry and Geochemistry and ${ }^{\dagger}$ MIT/WHOI Joint Program in \\ Chemical Oceanography, Woods Hole Oceanographic Institution, Woods Hole MA \\ 02543. \\ ${ }^{*}$ Corresponding author \\ phone: 508-289-3748 \\ fax: 508-457- 2076 \\ email: drogers@whoi.edu
}

Draft in preparation for Limnology and Oceanography 


\begin{abstract}
Isotopic and molecular techniques were combined to investigate where denitrification may occur within a transect through a coastal aquifer prior to discharge of the groundwater into Waquoit Bay, MA. The sampled aquifer shows three distinct parcels of water each with its own nutrient, oxygen and salinity characteristics. The surface salt zone, observed in the upper meter of the sediment column, was characterized by a nitrate pool enriched in both $\delta^{15} \mathrm{~N}$ (up to $+20.1 \%$ ) and $\delta^{18} \mathrm{O}$ (up to $+11.7 \%$ ), characteristic of groundwater affected by denitrification. The near-surface sediments also harbored a denitrifying community containing the nitrite reductase genes nirK and nirS. This contrasts with the deep salt wedge, where a more abundant nirS gene characterized the denitrifying community. Interestingly, the large nitrate pool in the fresh groundwater parcel appears to advect seaward without substantial change along the transect.
\end{abstract}




\section{Introduction}

Denitrification is an important mechanism for nitrogen removal in estuaries and coastal sediments (Seitzinger et al. 2006). More than half of the inorganic nitrogen entering estuaries and coastal ecosystems may be removed by this microbially-mediated process (Seitzinger 1988). Fresh water may also enter the coastal ocean through submarine groundwater discharge (Moore 1999; Burnett and Dulaiova 2003), and the amount of inorganic nitrogen introduced through SGD could be influenced by microbial processes occurring within the subterranean estuary. Previous studies have shown that the chemical load of nutrients, trace metals, organic carbon, and methane (Bugna et al. 1996; Paerl 1997; Cai et al. 2003) discharged from ground waters can rival that of riverine input, although the total water flux may be less (Burnett et al. 2003; Slomp and Van Cappellen 2004; Kroeger et al. 2007). Unlike many coastal or estuarine sediments, where water flows over the sediments with only tidal and pressure driven ventilation, groundwater flows through aquifer sediments resulting in a much larger exposure of the water parcel to reactive sediment surfaces and associated microbial communities. Groundwater is also isolated from the atmosphere, which allows for gradual depletion of oxygen along its flow path. These important environmental differences between overland and groundwater transport may contribute to different microbial consortia and nitrogen dynamics within aquifer sediments compared with more traditional riverine or estuarine sediments.

Denitrifying microbes are phylogentically diverse, and are found in all three domains of life, though mostly within the prokaryotes. In addition, many denitrifiers are 
closely related to non-denitrifying microbes, making $16 \mathrm{~S}$ rRNA genes an insufficient genetic marker for this metabolism (Zumft 1992; Braker et al. 2000). Genetic markers commonly used to assess the abundance and diversity of denitrifying bacteria are the genes for the dissimilatory nitrite reductase enzymes that catalyze the reduction of nitrite to nitric oxide, the first gaseous product in the denitrification pathway (Ward 1996; Braker et al. 2000). Nitrite reductase occurs in at least two major forms, a multi-heme cytochrome containing enzyme (encoded by the $\operatorname{nir} S$ gene) and a copper-containing protein (encoded by the nirK gene) (Zumft 1997). Recent work has used these genes to describe the distribution and diversity of denitrifying microbes in coastal sediments and groundwater systems (Braker et al. 1998; Nowicki et al. 1999; Braker et al. 2000; Nogales et al. 2002; Santoro et al. 2006).

The presence of an organism, or a gene, does not necessarily indicate activity, however, particularly for a facultative process such as denitrification. Additional measures are needed to determine where and when denitrification is occurring. Hence, stable isotope tracer techniques have been applied to many different environments to detect denitrification (Fukada et al. 2004). In addition, changes to the natural abundance stable isotopic signatures of nitrogen oxides can indicate potential locations of denitrification (Aravena and Robertsona 1998). Biological, chemical and physical processes can fractionate compounds due to isotopic differences between molecules. This fractionation can yield information about the reaction history of the compound. In particular, with nitrate $\left(\mathrm{NO}_{3}{ }^{-}\right)$both the nitrogen and oxygen atoms can be used to track isotopic fractionations and distinguish removal of $\mathrm{NO}_{3}{ }^{-}$via denitrification from dilution 
and mixing (Böttcher et al. 1990). The goal of this study was to investigate the removal of nitrate within a subterranean estuary on Cape Cod, MA by identifying regions of denitrification and characterizing the microbial communities in these regions, using a combination of molecular and stable isotopic techniques. Given that nutrient input through SGD may cause increased eutrophication of the coastal ocean (Valiela et al. 1992; Paerl 1997; Bricker et al. 1999), it is important to understand how these fluxes are mediated from both chemical and microbiological perspectives.

\section{Methods}

\section{Sample Collection}

During June and July 2008 pore water profiles were obtained along transects normal to the shoreline through the intertidal zone. The transect was composed of four sites beginning with a site $1 \mathrm{~m}$ above mean high-tide and extending through the intertidal zone (Figure 1). Pore water was collected using a piezometer with a stainless steel "Retract-a-tip" (AMS, Idaho), and vertical resolution was as small as $0.15 \mathrm{~m}$. After flushing with at least one liter of pore water (more than 6-fold flushing of tubing volume), $\mathrm{pH}$, dissolved oxygen, salinity and temperature were measured using a YSI 600R multi-probe (Charette and Sholkovitz 2002). Oxygen, $\mathrm{pH}$, and redox sensors were calibrated against standard solutions following the manufacturers protocols prior to deployment in the field. Triplicate pore water samples for isotopic $\left(\mathrm{NO}_{3}{ }^{-}, \mathrm{NO}_{2}{ }^{-}\right)$and

nutrient analyses $\left(\mathrm{NO}_{3}{ }^{-}, \mathrm{NO}_{2}{ }^{-}, \mathrm{NH}_{4}{ }^{+}\right)$were collected at a resolution of $0.15 \mathrm{~m}$ to $0.30 \mathrm{~m}$ through the top of the deep salt wedge (3-4 m), filtered through a $0.2 \mu \mathrm{m}$ pore-size 
Sterivex filter, kept on ice and either analyzed upon return to laboratory or frozen for later analysis.

After pore water sampling (on a falling tide), a sediment core (near low tide) was collected at site B using a hand-operated bailer-boring auger (Eijkelkamp, The Netherlands). The recovered sediment was sampled using aseptic techniques. Sediment samples for DNA analyses (ca. $1 \mathrm{~g}$ and $5 \mathrm{~g}$ of sediment) were frozen in liquid nitrogen for later processing.

\section{Nutrient concentration and isotopic analyses}

Nitrite concentrations were measured spectrophometrically after Pei et al. (1990). Nitrate plus nitrite $\left(\mathrm{NO}_{\mathrm{x}}\right)$ concentrations were measured by chemiluminescence following a hot vanadium reduction (Cox 1980; Garside 1982; Garside 1985). Ammonium was measured using the phenolhypochlorite method (Solorzano 1969).

The nitrogen and oxygen isotope ratios of nitrate (expressed in delta notation as $\delta^{15} \mathrm{~N}_{\mathrm{NO} 3}$ and $\delta^{18} \mathrm{O}_{\mathrm{NO} O}$, respectively) were measured after conversion to $\mathrm{N}_{2} \mathrm{O}$ using the denitrifier method (Sigman et al. 2001; Casciotti et al. 2002). $\delta^{15} \mathrm{~N}_{\mathrm{NO} 3}$ and $\delta^{18} \mathrm{O}_{\mathrm{NO} 3}$ values are reported in \%o vs. air and Vienna Standard Mean Ocean Water (VSMOW), respectively, and are calibrated to these scales by analyzing 20 nanomole (nmol) aliquots of the potassium nitrate reference materials USGS32, USGS34, and USGS35 after every 9 samples. Samples were also analyzed at the $20 \mathrm{nmol}$ level to match the standards. All isotopic measurements were made using a Thermo-Finnigan Delta ${ }^{\text {PLUS }} \mathrm{XP}$ isotope-ratio 
mass spectrometer with a custom-built continuous flow inlet similar to that described previously (Casciotti et al. 2002).

\section{DNA extraction}

DNA was extracted from the aquifer sediments using lysozyme $\left(5 \mathrm{mg} \mathrm{mL}^{-1}, 1 \mathrm{hr}\right.$, $\left.37^{\circ} \mathrm{C}\right)$ and proteinase $\mathrm{K}\left(2 \mathrm{mg} \mathrm{mL} \mathrm{m}^{-1}, 2 \mathrm{hr}, 60^{\circ} \mathrm{C}\right)$ digestions in lysis buffer $(200 \mathrm{mM}$ Tris$\mathrm{HCl}, 4 \%$ sodium dodecyl sulfate, $100 \mathrm{mM} \mathrm{NaCl}, 100 \mu \mathrm{g} \mathrm{mL}^{-1}$ polyadenosine, $\mathrm{pH} 8.0$ ) followed by three to five iterations of 3 minutes in a dry-ice/ethanol bath and 5 minutes $60{ }^{\circ} \mathrm{C}$ water bath, DNA was purified using three phenol:chloroform:isoamyl alcohol separation and final isopropanol precipitation. Recovered DNA was resuspended in 50 $\mu \mathrm{L}$ of TE for all subsequent analyses.

\section{Quantitative PCR}

Quantitative PCR, using an iCycler thermocycler (Bio-Rad, Hercules, CA), was employed to determine the gene copy numbers of nirK and nirS at $0.30 \mathrm{~m}$ resolution throughout the depth of the core. Triplicate DNA extractions of each sample were diluted to $10 \mathrm{ng} \mu \mathrm{l}^{-1}$ and amplified using either the iQ SYBR green Supermix (Bio-Rad) or a cocktail consisting of $1 \mathrm{X}$ colorless master mix (Promega, Madison, WI) amended with 10 nM dNTPs (Promega), 0.5 X SBYR-Green I (Invitrogen, Carlsbad CA), 20 nM

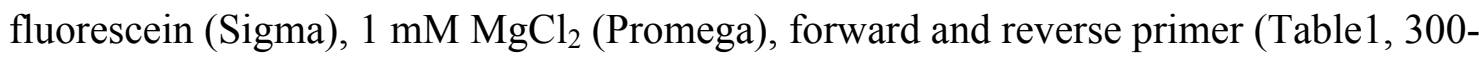
$1000 \mathrm{nM}$ ) and 1.25 units of GoTaq Flexi polymerase (Promega). All qPCR amplifications were repeated on three separate days using optimized thermal programs and resulted in a 
PCR efficiency between $88-92 \%$ (Table 1 and references therein). Standard curves were constructed from serial dilutions ( $10^{7}$ to $10^{1}$ copies $\mu \mathrm{L}^{-1}$ plus a water blank) of linearized p-Gem T-Easy plasmids (Promega) containing inserts of the functional gene of interest (Table 1). Plasmids $\left(0.5 \mu \mathrm{g} \mu \mathrm{L}^{-1}\right)$ were linearized by digestion with the EcoRI (New England Biolabs) restriction enzyme in the supplied buffer $\left(2 \mathrm{hr}\right.$ at $37^{\circ} \mathrm{C}$, heat inactivation $20 \mathrm{~min}$. at $65^{\circ} \mathrm{C}$ ). Restriction digests were cleaned using the SV Wizard PCR purification kit (Promega), eluted in $30 \mu \mathrm{L}$ ) and quantified using a Nanodrop spectrophotometer (Thermo-Fisher). Melt curves were performed on all reactions to confirm specificity.

\section{PCR, Cloning and Sequencing}

For each target gene (nirK and nirS), three replicate PCR amplifications from $1 \mathrm{~m}$ (shallow salt zone), $2 \mathrm{~m}$ (freshwater peak) and $3 \mathrm{~m}$ (deep salt wedge) were conducted according to published protocols (Table 1 and ref. therein). The replicate amplification products were pooled and cleaned with the SV Wizard PCR Clean-up (Promega) following the manufacturers protocols and eluted in $50 \mu \mathrm{L}$ Tris-EDTA (TE) buffer. Cleaned amplicons were ligated using the p-Gem T-Easy vector kit (Promega) using the manufacturers protocols and transformed into chemically competent E. coli JM109 using standard procedures (Seidman et al. 2002). The transformants were plated on Luria Broth plates containing IPTG/X-gal/ampicillin ( $10 \mu$ mols, $1 \mathrm{mg}$ and $50 \mu \mathrm{g} \mathrm{mL}^{-1}$ respectively) and incubated at $37{ }^{\circ} \mathrm{C}$ for $24 \mathrm{hr}$. Blue/white screening was used to pick individual 
colonies, which were transferred to growth blocks containing Superbroth (Difco) with ampicillin $\left(50 \mu \mathrm{g} \mathrm{mL}^{-1}\right)$ and grown shaking $(250 \mathrm{rpm})$ overnight. The overnight cultures were harvested by centrifugation ( $2800 \mathrm{rpm}$ for $8 \mathrm{~min}$. at $\left.4{ }^{\circ} \mathrm{C}\right)$. Plasmid purification and sequencing were performed at the Keck Facility, Josephine Bay Paul Center at the Marine Biological Laboratories (JBPC-MBL, Woods Hole, MA) using a BiomekFX workstation (Beckman Coulter) and a 3730XL capillary sequencer (Applied Biosystems).

Sequencing chemistry was a modified Big-Dye reaction containing $0.5 \mu 1$ of BigDye Terminator, $0.4 \mu \mathrm{L}$ of primer (M13R 5'-CAGGAAACAGCTATGAC-3', $15 \mu \mathrm{M}$ ), $0.1 \mu \mathrm{L}$ dimethyl sulfoxide, $1 / 3 \mathrm{X}$ reaction buffer, template (200-400 ng DNA) and water to a final volume of $6 \mu \mathrm{L}$ per reaction. A thermal program of 60 cycles of $96^{\circ} \mathrm{C}$ for 10 sec., $50{ }^{\circ} \mathrm{C}$ for $5 \mathrm{sec}$. and $60{ }^{\circ} \mathrm{C}$ for $4 \mathrm{~min}$. was used. Following reaction, the DNA was precipitated by a series of $75 \%$ and $70 \%$ isopropanol washes, air dried and finally resuspended in $7 \mu \mathrm{L}$ Hi-Di formamide and frozen until sequencing.

\section{Sequence analysis}

Successful sequencing reads were checked and the vector trimmed at the JBPCMBL (Woods Hole, MA). Base calling and sequence quality was performed by the Phred and Phrap software packages (Ewing and Green 1998; Ewing et al. 1998). The Lucy software (Chou and Holmes 2001) was used for vector trimming. These processed sequences were searched against the non-redundant nucleotide (nr/nt) database using the blastn algorithm. 16S rRNA sequences, and related GenBank sequences, were imported into ARB, aligned with the ARB aligner and manually checked (Ludwig et al. 2004). 
Conservative column filters were constructed masking any sites where data was missing. Trees were constructed on the aligned sequences using the ARB neighbor joining function. NirS and nirK gene sequences were treated in the same manner using databases built from nirS and nirK sequences from GenBank.

\section{GenBank Submission}

All sequencing generated and used in this study are reported to GenBank under the accession numbers HM160368-HM160497.

\section{Results}

\section{Nutrient Chemistry}

The distributions of salinity and nutrients in the near-shore aquifer at the head of Waquoit Bay have been described in detail in previous studies of the system (Charette et al. 2005; Charette and Sholkovitz 2006; Kroeger and Charette 2008). In short, the aquifer has three major features: 1) a surface salt zone (salinity of 4-6) driven by tidal and/or wave action, 2) a oxidized freshwater plume and 3) a reduced deep salt wedge. The intrusion of deep salt wedge beneath the seaward-flowing freshwater plume results in a shoaling of the ground water plume and a deep salt wedge in the seaward stations in the transect (Figure 2A). A reducing, ammonium and iron rich freshwater plume was never observed at the current study site but has been reported previously at study sites on the eastern portion of the bay studies at a site east of the site (see Charette et al. 2005, Kroeger and Charette 2008). 
Nitrate is the dominant species of inorganic nitrogen $(>350 \mu \mathrm{M})$ in the freshwater portion of the aquifer. Nitrate decreases to concentrations as low as $12.5 \mu \mathrm{M}$ within the surface brackish layer and is undetectable in the deep salt wedge (Figure 2C). The oxygen distribution is similar to the nitrate distribution, with elevated concentrations within the freshwater plume and decreasing towards the two saline water parcels. In the surface salt zone, oxygen decreases to ca. $20 \mu \mathrm{M}$. A similar decrease in oxygen is seen between the freshwater plume and the deep salt wedge (Figure 2B). On the other hand, ammonium is present only in the deep salt wedge at the time of our sampling (Figure 2D) and is consistent with organic matter remineralization in anoxic estuarine sediments (Talbot et al. 2003; Kroeger and Charette 2008).

The lowest isotope ratios for both $\delta^{15} \mathrm{~N}_{\mathrm{NO} 3}$ and $\delta^{18} \mathrm{O}_{\mathrm{NO} 3}$ are found within the core of the freshwater plume, with $\delta^{15} \mathrm{~N}_{\mathrm{NO} 3}$ values of 4-5\% (Figure $3 \mathrm{~A}$ ) and $\delta^{18} \mathrm{O}_{\mathrm{NO} 3}$ values of 2-3\% (Figure 3B). Both $\delta^{15} \mathrm{~N}_{\mathrm{NO} 3}$ and $\delta^{18} \mathrm{O}_{\mathrm{NO} 3}$ increased into the surface salt zone as nitrate concentrations decreased (Figure 3A, 3B, 2C). These patterns are consistent with nitrate removal by a process with normal fractionation, rather than through advection or dilution that ought not result in fractionation. Nitrate isotopic measurements within the deep salt wedge were not possible because sampling resolution within the steep gradient in nitrate concentrations did not yield samples within our analytical limit (Figure 2C).

The $\delta^{18} \mathrm{O}_{\mathrm{H} 2 \mathrm{O}}$ was also measured throughout the transect in order to constrain the $\mathrm{d}^{18} \mathrm{O}$ value of local nitrate production (Figure $3 \mathrm{C}$ ). $\delta^{18} \mathrm{O}_{\mathrm{H} 2 \mathrm{O}}$ values correlated with salinity $\left(r^{2}=0.71\right)$ with the most depleted values $(-8 \%)$ occurring within center of the freshwater plume (Figure 3D). The $\delta^{18} \mathrm{O}_{\mathrm{H} 2 \mathrm{O}}$ increased by $2 \%$ moving up from the center of the 
freshwater plume, and approached -6\%o in the surface brackish zone. The gradient in $\delta^{18} \mathrm{O}_{\mathrm{H} 2 \mathrm{O}}$ was greater moving from the center of the plume toward the deep salt wedge, with values as high as $-1.8 \%$ in the salt wedge, at salinities of 26.2 (Figure 3C, D).

\section{Nitrite reductase abundance and distribution}

In the Waquoit Bay aquifer, both nirS and nirK were detected at all depths (Figure 5). Of the two genes, nirK displayed less variability with depth, ranging only from $1.53 \mathrm{x}$ $10^{4}$ to $1.55 \times 10^{5}$ copies per gram sediment throughout the core. The maximum abundance for $\operatorname{nir} K$ occurred at a depth of $2 \mathrm{~m}$ while the minimum was found at $1 \mathrm{~m}$. The abundance of $\operatorname{nir} K$ in the aquifer sediments is similar to abundances reported for soils, more specifically low carbon and low nitrogen soils (Henry et al. 2004). In contrast, nirS abundances varied by more than two orders of magnitude, from $7.83 \times 10^{2}$ copies per gram sediment at $1 \mathrm{~m}$ depth to $6.8 \times 10^{5}$ copies per gram sediment at $3.8 \mathrm{~m}$ depth. These abundances are similar in range to reports for the Colne estuary sediments (United Kingdom) where the highest abundances were observed at the head of the estuary and copy numbers decreasing moving toward the estuary mouth (Smith et al. 2007).

\section{Bacterial 16S rRNA Gene Diversity}

Phylogenetic analysis of the bacterial 16S rRNA genes designated 11 operational taxonomic units using a cutoff of $97 \%$ sequence identity. The Proteobacteria division dominated the bacterial community, with members from the gamma- and alphasubdivisions accounting for $43 \%$ and $28 \%$ of the population respectively. Lesser 
contributions were from the Actinobacteria-, Firmicute- and Planctomycetales-like organisms.

The genes recovered from the gamma-Proteobacteria division were recovered from all depths of the core. Alcanivorax-like organisms are often observed in environments altered by hydrocarbon pollution and/or haline environments (Kasai et al. 2002). The Alcanivorax-like sequences recovered from the aquifer are most closely related to genes recovered from marine sources such as deep-sea sediments and the water column of the North Sea. Alteromonad-like organisms are commonly found in coastal and open ocean waters, often in the deep-sea (Mikhailov and Ivanova 1995). These organisms are generally aerobic heterotrophs. Sequences closely related to the genes recovered from the aquifer have been obtained from deep-sea sediments (Reed et al. 2002), groundwater (Gihring et al. 2006), and surface seawater (Bano and Hollibaugh 2002) environments. Xanthomonas-like organisms, often associated with plant degradation and disease, are commonly in soil environments.

The alpha-Proteobacteria are represented in the aquifer by Erythrobacter-, Mesorhizobium- and Rhodobacter-like 16S rRNA genes. Erythrobacter-like sequences were recovered from the shallow and deep salinity zones in the core. Erythrobacteria are common photohetertrophs in nutrient-rich coastal waters (Koblížek et al. 2003). The isolated representatives from this group cannot use nitrate as a nitrogen source, but instead require ammonium, urea or amino acids (Koblížek et al. 2003).

Other alpha-Proteobacteria recovered from the aquifer are closely related to known denitrifying organisms. Mesorhizobium-like organisms are often capable of 
nitrogen-fixation and are typically symbiotic with leguminous plants. However, cultured Mesorhizobium species have also been shown to denitrify under microaerobic conditions (Okada et al. 2005; Monza et al. 2006). Related sequences have also been recovered from uranium contaminated soils (Brodie et al. 2006), ferromanganese deposits (Northup et al. 2003) and aquiculture biofilters. Rhodobacter-like organisms are common in both freshwater and marine habitats. These organisms are known for their very plastic metabolism ranging from phototrophy to lithotrophy, aerobic and anaerobic respiration, including denitrification (Schwintner et al. 1998; Liu et al. 1999). The genes recovered from the aquifer are most closely related to various Stappia sp. within the Rhodobacter order. Stappia contains members that are known denitrifiers (Weber and King 2007). Interestingly, the species with the most closely related $16 \mathrm{~S}$ rRNA sequences to those recovered from the aquifer have been shown to denitrify (Pujalte et al. 2005). Mesorhizobium- and Rhodobacter-like sequences were recovered throughout the sediment core and represent potential denitrifying organisms in the nitrate-rich environment.

Actinobacteria-like organisms are common soil microorganisms known for their ability to degrade refractory organic matter such as cellulose and chitin but also for the production of secondary metabolites such as antibiotics (Bull and Stach 2007). Actinobacteria-like sequences were only recovered from the upper two meters. Firmicute-like organisms are another common soil microorganism that are classically divided into the anaerobic (Clostridia) and aerobic (Bacilli) groupings. All of the Firmicute-like sequences obtained from the aquifer were related to the anaerobic 
Clostridia class with the most closely related sequences recovered from anaerobic wastewater digesters (Tang et al. 2004), groundwater and uranium contaminated soils (Brodie et al. 2006). These sequences were recovered from three meters and deeper, Planctomycetales-like organisms include the anammox-like organisms as well as other aquatic (marine, brackish and freshwater) organisms. Organisms of this affiliation were recovered from all depths.

\section{Discussion}

Nitrogen inputs into groundwater on Cape Cod are primarily derived from wastewater (48 \%) with lesser contributions from atmospheric deposition (29\%) and fertilizer (16\%) (Valiela et al. 1997; Valiela et al. 2000). Nitrate from the freshwater portion of the aquifer constitutes the bulk of the DIN transport to the head of the bay and has been calculated to supply $6.2 \mathrm{~kg} \mathrm{~N}$ day $^{-1}$ ( $80 \%$ of total) to the head of Waquoit Bay (Talbot et al. 2003). Model results suggest limited nitrate removal via denitrification is likely to occur within the oxidized, nitrate rich freshwater plume (Spiteri et al. 2008). However, below this freshwater plume, chemical data from a similar section through the groundwater aquifer show an increase in $\delta{ }^{15} \mathrm{~N}_{\mathrm{NO} 3}$ with decreasing nitrate concentrations (Kroeger and Charette 2008). Likewise, a similar pattern of increase $\delta^{15} \mathrm{~N}_{\mathrm{NH} 4}$ with decreasing ammonium concentration is also observed within an ammonium plume ( $>250$

$\mu \mathrm{M} \mathrm{NH}_{4}{ }^{+}$) of the freshwater parcel (Kroeger and Charette 2008). These authors interpret these data to reflect a loss of DIN (nitrate and ammonia) through a fractionating biogeochemical processes, presumably through coupled nitrification-denitrification or 
anammox (Kroeger and Charette 2008). Unfortunately, to date there is not enough evidence in regard to the isotopic signatures or genetic markers to adequately examine the role of anammox in the current study. The goal of the present study is to examine, using isotopic and molecular techniques, where denitrification occurs in the subterranean estuary and which groups of organisms might be involved in this process.

\section{Isotopic evidence for denitrification}

The fresh groundwater parcel contained low $\delta^{15} \mathrm{~N}_{\mathrm{NO} 3}$ and $\delta^{18} \mathrm{O}_{\mathrm{NO} 3}$ values of $5 \%$ and 3\%, respectively (Figure 3A, B). These values are similar to average seawater (Wada et al. 1975; Sigman and Casciotti 2001; Casciotti et al. 2002) and do not change as the transect moves toward the bay. The low $\delta{ }^{15} \mathrm{~N}_{\mathrm{NO} 3}$ values are consistent with the proposed anthropogenic source of nitrate to this parcel. Ammonium from wastewater has an expected $\delta^{15} \mathrm{~N}$ range of 5\% to $9 \%$ (Aravena et al. 1993). Although nitrification has a significant fractionation factor (Mariotti et al. 1981; Yoshida 1988; Casciotti et al. 2003), the $\delta^{15} \mathrm{~N}_{\mathrm{NO} 3}$ values would be expected to approach the $\delta^{15} \mathrm{~N}$ of the ammonium source when the ammonium pool is completely consumed within the freshwater plume at the time of our sampling.

The low values of $\delta^{18} \mathrm{O}_{\mathrm{NO} 3}$ in the fresh water plume suggest little alteration of the nitrate pool since its formation via nitrification. Nitrification adds oxygen atoms from both water and dissolved oxygen in approximately a 2:1 ratio. Exchange of nitrite with water during nitrification may lead to a greater dependence on water (Buchwald and Casciotti 2010; Casciotti et al. 2010). Due to this dependency on oxygen atoms from 
water, information about the $\delta^{18} \mathrm{O}_{\mathrm{H} 2 \mathrm{O}}$ can provide constraints on whether the nitrate is of local origin or derived from an external source. $\delta^{18} \mathrm{O}_{\mathrm{H} 2 \mathrm{O}}$ variations between $-8 \%$ and $-2 \% 0$ were well correlated $\left(r^{2}=0.71\right)$ with salinity (Figure 3D), suggesting mixing between coherent fresh and salt water sources. The depleted values for $\delta^{18} \mathrm{O}_{\mathrm{H} 2 \mathrm{O}}$ within the core of the freshwater plume are consistent with a meteoric source (-8\%o to -6\%) (Kendall and Coplen 2001), and are similar to reported $\mathrm{d}^{18} \mathrm{O}_{\mathrm{H} 2 \mathrm{O}}$ values for nearby river water, while the high-salinity end-member (ca. 80\% seawater) approached the average $\mathrm{d}^{18} \mathrm{O}_{\mathrm{H} 2 \mathrm{O}}$ for seawater $(0 \%)$. $\mathrm{NO}_{3}{ }^{-}$produced via nitrification with a source of water between $-8 \%$ and $2 \%$ is expected to have a d ${ }^{18} \mathrm{O}_{\mathrm{NO} 3}$ value between $-2.3 \%$ and $+0.2 \%$ (Buchwald and Casciotti 2010; Casciotti et al. 2010). This range is largely consistent with the observed $d^{18} \mathrm{O}_{\mathrm{NO} 3}$ values in the core of the fresh water plume, although the slightly higher $\mathrm{d}^{18} \mathrm{O}_{\mathrm{NO} 3}$ values observed in the aquifer could be the result of mixing with nitrate of higher $\mathrm{d}^{18} \mathrm{O}_{\mathrm{NO}}$ or partial consumption of $\mathrm{NO}_{3}{ }^{-}$within the plume.

Consumption of $\mathrm{NO}_{3}{ }^{-}$would be expected to leave the residual $\mathrm{NO}_{3}{ }^{-}$enriched in both ${ }^{18} \mathrm{O}$ and ${ }^{15} \mathrm{~N}$ (Mariotti et al 1981). This is most clearly observed in moving up through the sediment into the shallow salt zone. In this region the concentration of nitrate dropped (Figure 2) while the values of both $\delta^{15} \mathrm{~N}_{\mathrm{NO} 3}$ and $\delta^{18} \mathrm{O}_{\mathrm{NO} 3}$ increased (Figure 3). The gradients in the isotopic values were greatest in the uppermost meter of the aquifer. Over this distance, $\delta^{15} \mathrm{~N}_{\mathrm{NO} 3}$ values increased from $+10 \%$ to maximum values of $+20 \%$ o near the surface and $\delta^{18} \mathrm{O}_{\mathrm{NO} 3}$ values increase from $+5 \%$ to $+10 \%$ (Figure 3). The increase in $\delta^{18} \mathrm{O}_{\mathrm{NO} 3}$ was less than the increase in $\delta^{15} \mathrm{~N}_{\mathrm{NO} 3}$, resulting in a slope for $\delta^{18} \mathrm{O}_{\mathrm{NO} 3}$ vs. $\delta^{15} \mathrm{~N}_{\mathrm{NO} 3}$ of 0.56 (Figure 4). 
Alternative explanations for the increases in both $\delta^{15} \mathrm{~N}_{\mathrm{NO} 3}$ and $\delta^{18} \mathrm{O}_{\mathrm{NO} 3}$ towards the surface include: 1) addition of nitrate with high $\delta^{15} \mathrm{~N}$ and $\delta^{18} \mathrm{O}$ values and 2) isotopic fractionation during nitrate consumption within the aquifer. A detailed study of the groundwater in a different section of Waquoit Bay revealed a shallow nitrate plume with low $\delta^{15} \mathrm{~N}_{\mathrm{NO} 3}(+2.1 \%)$, which the authors interpreted as nitrate from atmospheric deposition (Kroeger and Charette 2008). Atmospheric deposition tends to have low $\delta^{15} \mathrm{~N}_{\mathrm{NO} 3}\left(-4 \%\right.$ to $+6 \%$ ) (Spoelstra et al. 2001; Burns and Kendall 2002) and high $\delta^{18} \mathrm{O}_{\mathrm{NO} 3}$ $(+25 \%$ o to $+75 \%$ ) (Durka et al. 1994; Spoelstra et al. 2001; Burns and Kendall 2002) values. This could explain increases in $\delta^{18} \mathrm{O}_{\mathrm{NO} 3}$, but is not consistent with an increase in $\mathrm{d}^{15} \mathrm{~N}$ (up to $+20 \%$ ). Addition of $\mathrm{NO}_{3}{ }^{-}$from atmospheric deposition is expected to result in greater increases in $\delta^{18} \mathrm{O}_{\mathrm{NO} 3}$ than in $\delta^{15} \mathrm{~N}_{\mathrm{NO} 3}$, which is not what we observe. The enrichments in $\delta^{18} \mathrm{O}_{\mathrm{NO} 3}$ and $\delta^{15} \mathrm{~N}_{\mathrm{NO} 3}$ suggest that the bulk of this nitrate in the surface salt zone at this location is not likely to arise from atmospheric deposition, unless significant microbial reprocessing has taken place since deposition (Barnes et al. 2008). Another potential source of nitrate to this zone could be through infiltrating seawater driven by wave or tidal mixing. However, nitrate introduced through this path would be expected to be isotopically similar to bay water, which has lower values of both $\delta^{15} \mathrm{~N}_{\mathrm{NO} 3}(+6.3 \pm$ $0.06 \%$ ) and $\delta^{18} \mathrm{O}_{\mathrm{NO} 3}(+3.8 \pm 0.05 \%$ ) than the surface aquifer (Figure 3 ).

The increasing values of both $\delta^{15} \mathrm{~N}_{\mathrm{NO} 3}$ and $\delta^{18} \mathrm{O}_{\mathrm{NO} 3}$ values co-occuring with decreasing nitrate concentrations are consistent with $\mathrm{NO}_{3}{ }^{-}$removal by an isotopically fractionating process. The data suggest that $\mathrm{NO}_{3}{ }^{-}$in the surface pore waters would have undergone partial consumption to reach the high $\delta^{15} \mathrm{~N}_{\mathrm{NO} 3}$ and $\delta^{18} \mathrm{O}_{\mathrm{NO} 3}$ values observed in 
the upper meter of sediment. The ratio of $\delta^{18} \mathrm{O}_{\mathrm{NO} 3}$ and $\delta^{15} \mathrm{~N}_{\mathrm{NO} 3}$ increase within this zone (Figure 4) was also consistent with reported values for denitrification in groundwater (slope $=0.47-0.77$ ), supporting the hypothesis of denitrification occurring in the upper sediments of the aquifer. Furthermore, we can calculate the fractionation factor $(\varepsilon)$ that would result from the consumption of nitrate in this zone from the freshwater peak (332 $\left.\mu \mathrm{M} \mathrm{NO}_{3}{ }^{-}\right)$to the surface $\left(46 \mu \mathrm{M} \mathrm{NO}_{3}{ }^{-}\right)$using a Rayleigh type model:

$$
\delta_{n}=\delta_{o}-\varepsilon \ln (f)
$$

where $\delta_{\mathrm{n}}$ is the isotope value at time $n, \delta_{\mathrm{o}}$ is the initial isotope value and $f$ is the fraction of nitrate remaining. This calculation provides an estimate of $+7.6 \%$ for $\varepsilon$, well within the reported range of values from known denitrifiers $(+5$ to $+35 \%$ ). The natural abundance stable isotopes thus provide compelling evidence for active denitrification. However, additional investigations are needed to constrain the instantaneous rates.

Below the fresh groundwater plume, the nitrate concentration drops rapidly approaching the deep salt wedge, resulting in a steep concentration gradient. Unfortunately, samples along this gradient with sufficient nitrate concentrations to measure the isotopic values were limited. However, based on the nitrate/salinity relationship and isotopic fractionation reported by others, the nitrate pool appears to mix non-conservatively within this lower portion of the aquifer. This suggests nitrate is removed between the freshwater and deep salt wedge.

We interpret these data collectively as representing a nitrate pool produced somewhere upstream of the transect zone that remains largely unchanged at its core during its transit through the area covered by our transect. At both the surface salt zone 
and deep salt wedge transitions, nitrate removal appears to occur under lowered $\mathrm{O}_{2}$

conditions. In the surface salt zone at the landward end of the transect, both $\delta^{15} \mathrm{~N}_{\mathrm{NO} 3}$ and $\delta^{18} \mathrm{O}_{\mathrm{NO} 3}$ values increase with decreasing nitrate concentrations, which is consistent with denitrification. The question now becomes which organisms might be responsible for this consumption of nitrate.

\section{Molecular evidence for denitrification}

Modern molecular techniques can be used to shed light on which organisms and perhaps which metabolisms could be functioning at different depths within the aquifer sediments. In a general overview the bacterial 16S rRNA gene clone libraries suggest that the Waquoit Bay groundwater system harbors organisms that are likely adapted to nutrient-amended environments. Many of the sequences recovered in this study such as the gamma-Proteobacteria, Planctomycetales- and Firmicute-like organisms indicate adaptation to anaerobic sediments and soils. Given that many of these sequences have been recovered from wastewater or sludge bioreactors it may be that these organisms are also adapted to high nitrate, low oxygen environments. The study site at Waquoit Bay contains steep gradients in nutrient and oxygen concentrations that may set boundaries on the distribution of organisms within this environment. To evaluate this, we combined phylogenetic analysis of the $16 \mathrm{~S}$ rRNA, nirK and nirS genes as well as the quantitative depth distribution of the two functional genes through the sediment column. 


\section{The upper meter}

The upper meter of the sediment column represents an area that likely harbors denitrifying organisms. Analysis of the $16 \mathrm{~S}$ rRNA genes recovered from the upper meter shows that it is dominated by alpha-and gamma-Proteobacteria. Many of these organisms are related to aerobic heterotrophs from environments such as marine and estuary sediments, marine water column and groundwater environments among others. Notably, Mesorhizobium-like and Stappia-like sequences were recovered from this depth range but not in the deeper regions of the sediment column. The Stappia-like sequences may represent a very versatile metabolic lifestyle that potentially includes denitrification (Kroeger and Charette 2008). Mesorhizobium-like organisms include known nitrogenfixers as well as some aerotolerant denitrifying strains (Weber and King 2007). Mesorhizobium-like organisms have been implicated in the nirK-mediated denitrification in rhizosphere environments (Okada et al. 2005), wastewater (Yoshie et al. 2004) and soils (Sharma et al. 2005). This finding is congruent with the abundance data that shows nirK genes are more abundant than nirS in the upper meter of the sediment column. The nirK sequences recovered from this region of the aquifer, as well as from other sections, are also most closely related to terrestrial organisms such as Mesorhizobium-, Rhodobacter-, and Hyphomicrobium-like organisms. Consistent with low abundance levels, only one sequence type of $\operatorname{nir} S$ was retrieved from the upper meter of the sediment column most closely related to the beta-Proteobacterium Ralstonia sp. Taken together with the chemical data above the surface salt zone appears to be a zone of active denitrification carried out by a soil or sediment type microbial community. 
The Freshwater Plume

The freshwater plume contains elevated nitrate and oxygen concentrations and depleted isotopic values for both $\delta^{15} \mathrm{~N}_{\mathrm{NO} 3}$ and $\delta^{18} \mathrm{O}_{\mathrm{NO} 3}$. As described above, the chemical signatures do not indicate appreciable denitrification in this zone. Many of the 16S rRNA genes recovered from this depth are also present in the $1 \mathrm{~m}$ and the $3 \mathrm{~m}$ samples.

Sequences related to various alpha- and gamma-Proteobacteria including Alteromonaslike organisms were most common. Alteromanades are common marine heterotrophs, ranging from coastal waters to open ocean and deep-sea habitats that have also been implicated in denitrification (Bremer et al. 2007). At this depth nirS gene abundance has increased to a level equal to nirK gene abundance. Without a chemical signature for denitrification, and given that these are gene abundance values and not transcript (mRNA) abundance, we interpret the presence of these genes at this depth as indicating the presence of potential denitrifiers that are utilizing another metabolic pathway. Within the freshwater plume, the high oxygen concentrations are expected to inhibit traditional denitrifying organisms. Studies have shown denitrification can be inhibited by oxygen concentrations above $10 \mu \mathrm{M}$ for environmental studies (Enger et al. 1987), though some cultured isolates have displayed greater aerotolerance. For example, cultures of Pseudomonas stuzeri, a well-studied denitrifying bacterium, has been shown to denitrify in up to $150 \mu \mathrm{M}$ oxygen (Nielsen et al. 1990). However, our isotopic and chemical data suggest that the nitrate in the well-oxidized fresh groundwater is largely unaltered by denitrifcation, regardless of the abundance of denitrification genes at this depth. 


\section{Deep Salt Wedge Transition}

The transition between the freshwater plume and deep salt wedge results in a steep gradient in nitrate and oxygen concentrations. Recent reports suggest that denitrification does occur within this zone (Korner and Zumft 1989). Interestingly, there is a transition observed in the $16 \mathrm{~S}$ rRNA gene libraries at this depth. The sequences recovered from three meters and below are most commonly represented by sequences related to Erythrobacter (also seen in upper meter), Clostridia and Planctomycetales. Clostridia- and Planctomycetales-like sequences were not recovered in the surface salt zone. Similar sequences have been recovered from coastal marine waters (Erythrobacterand Planctomycetes- but not Clostridia-like), anaerobic soils and marine sediments (Kroeger and Charette 2008), groundwater, contaminated soils (Tang et al. 2004) and wastewater reactors (Clostridia- and Planctomycetales- but not Erythrobacter-like). Plancotmycetales are organisms of special interest in nitrogen cycling because some members of this phylum have also been implicated in anammox, although the sequences recovered from the aquifer are more closely related to sequences obtained from marine sediments and soils. Planctomycetes are common constituents of soil and marine sediment microbial communities and some have very broad metabolic capabilities as well as complex life cycles.

Nitrite reductase genes from the deep salt wedge are different than found in the upper meter. NirS increases by 3 orders of magnitude compared to the surface salt zone, becoming dominant over the nirK gene (Figure 5). Recovered nirS genes are most closely 
related to Marinobacter-, Pseudomonas- and Paracoccus-like organisms. The presence of these genes and organisms suggests that denitrification is possible as suggested by earlier chemical studies (Brodie et al. 2006). The isotopic and chemical signature of groundwater denitrification is not observed in the present study, most likely because of the steep nitrate gradient at depth, which prevented our natural abundance isotopic measurements due to detection limitations $\left(0.5 \mathrm{mM} \mathrm{NO}_{3}{ }^{-}\right.$required $)$.

Another pathway for nitrogen removal is anammox. Anammox traditionally combines ammonia and nitrite to form dinitrogen, in contrast to classical denitrification that uses only the oxidized nitrogen species. Previous (Kroeger and Charette, unpublished) and concurrent incubation studies (Rogers and Casciotti, unpublished) using isotopic tracers did not detect significant rates of anammox in the subterranean estuary, although both denitrification (Kroeger and Charette, unpublished) and nitrification (Chapter 4) were observed. Interestingly, ladderane lipids that are thought to be specific to anammox were recovered from the aquifer sediments (Saenz, unpublished). Recent reports have suggested that anammox organisms may contain a specific type of nirS gene that could be quantified separately from the classical denitrifiers in the environment (Kroeger and Charette 2008). This was not pursued in the present study because the nirS sequences from anammox-like organism were not available at the time this study was conducted. Given the presence of lipid markers and the reported non-conservative behavior of ammonium in the mixing zone between the freshwater plume and deep salt wedge (Lam et al. 2009) anammox processes are expected to be active in the aquifer. There are several reasons the present study may have missed anammox in the aquifer. 
The steep gradient in nitrate within this deep mixing zone limits our analysis in terms of sample number for both concentration and natural abundance isotopes and we do not observe a nitrite pool. Even if natural abundance isotope values were available, it is not known what signal is produced by biological or manganese-oxide mediated anammox processes. In our tracer level studies handling of the samples, especially exposure to elevated oxygen concentrations, may temporarily or permanently inhibit the anaerobic microorganisms. The reaction rate of bacterially mediated anammox could also be slow enough that it cannot be observed over the time course of the incubation experiment. Finally, the requirement of both reduced ammonium and oxidized nitrite and an anaerobic zone for the anammox process is likely to also require the steep gradients and associations with aerobic organisms for the production of nitrite. The incubations used here were designed to eliminate gradients that may obscure nitrification or denitrification processes. Clearly, this area of research will benefit from future targeted studies and technique development in both isotopic methods and the development of molecular markers.

\section{Implications}

The results of the chemical interrogation of the study site reveal three distinct zones: 1) a shallow salt zone with low pore water $\mathrm{O}_{2}$ and nitrate concentrations, 2) a fresh, oxidized nitrate plume (up to $350 \mu \mathrm{M}$ nitrate) and 3) a deep intruding salt wedge that is rich in ammonium, but lacking oxygen and nitrate. While each of these environments harbors communities that are capable of cycling and removing nitrogen 
before the aquifer waters are discharged into coastal waters, our data suggest that the fringes, rather than the central plume, may be the most active denitrification zones. The surface salt zone displays a pattern of decreasing nitrate and elevated $\mathrm{d}^{15} \mathrm{~N}_{\mathrm{NO} 3}$ and $\delta^{18} \mathrm{O}_{\mathrm{NO} 3}$ that are consistent with previously observed groundwater denitrification. Moreover, the organisms present are representative of soil/sediment type organisms including many potential denitrifiers. In contrast, the community as assayed by the nir genes reveals a low diversity of denitrifiers, with nirK playing an important role. Removal of nitrogen from the transition between the freshwater plume and deep salt wedge is also likely where the community shifts to a $\operatorname{nir} S$ dominated denitrifier community. This microbial community appears more closely related to marine or reducing sediment/wastewater type organisms. The elevated oxygen levels within the freshwater nitrate plume most likely inhibit denitrification, although available carbon or electron donors may also be limiting. Of course, the processes that occur where the freshwater plume discharges into a saline environment may be similar to the salinity transition zones observed in this study, and may yet have the potential to attenuate $\mathrm{NO}_{3}{ }^{-}$ concentrations prior to discharge.

\section{Acknowledgements}

The authors would like to thank the Waquoit Bay National Estuarine Research Reserve for site access and logistical support. Kevin Kroeger, Matt Charette, Paul Henderson, Matt Mcllvin, Erin Banning, Megan Gonneea, Sandy Baldwin, Laura Erban for field, laboratory assistance, and helpful comments and discussion. Funding from 
NSF/OCE 0524994 to MC, KK, KLC, Katrina Edwards and WHOI COI to DRR and KLC and WHOI OVF to DRR. 
Table 1. qPCR primers and thermal programs.

\begin{tabular}{|c|c|c|c|c|}
\hline $\begin{array}{c}\text { Target } \\
\text { Gene }\end{array}$ & $\begin{array}{c}\text { Primer Names } \\
\text { And } \\
\text { Sequences }\end{array}$ & Thermal Program & $\begin{array}{l}\text { Positive } \\
\text { Control }\end{array}$ & Reference \\
\hline $\operatorname{nirS}$ & $\begin{array}{l}\text { nirSch3AF (1000nM) } \\
\text { GTSAACGTSAAGGARACS } \\
\text { GG } \\
\text { nirSR3cd (1000nM) } \\
\text { GASTTCGGRTGSGTCTT } \\
\text { A }\end{array}$ & $\begin{array}{l}50^{\circ} \mathrm{C} \text { for } 120 \mathrm{sec} \\
95^{\circ} \mathrm{C} \text { for } 600 \mathrm{sec} \\
40 \text { cycles of } \\
95^{\circ} \mathrm{C} \text { for } 60 \mathrm{sec} \\
50^{\circ} \mathrm{C} \text { for } 60 \mathrm{sec} \\
60^{\circ} \mathrm{C} \text { for } 60 \mathrm{sec} \\
80^{\circ} \mathrm{C} \text { for } 15 \mathrm{sec}(\mathrm{read})\end{array}$ & $\begin{array}{l}\text { Psuedomonas } \\
\text { stuzeri }\end{array}$ & $\begin{array}{l}\text { (Throback et al. } \\
\text { 2004; Kroeger and } \\
\text { Charette 2008) }\end{array}$ \\
\hline $\operatorname{nirK}$ & $\begin{array}{l}\text { nirK876 (500nM)- } \\
\text { ATYGGCGGVAYGGCGA } \\
\text { nirK1040 (500nM)- } \\
\text { GCCTCGATCAGRTTRTGG } \\
\text { TT }\end{array}$ & $\begin{array}{l}50^{\circ} \mathrm{C} \text { for } 120 \mathrm{sec} \\
95^{\circ} \mathrm{C} \text { for } 900 \mathrm{sec} \\
6 \text { cycles of } \\
95^{\circ} \mathrm{C} \text { for } 15 \mathrm{sec} \\
63-58^{\circ} \mathrm{C} \text { for } 60 \mathrm{sec}(- \\
\left.1^{\circ} \mathrm{C} / \text { cycle }\right) \\
72^{\circ} \mathrm{C} \text { for } 30 \mathrm{sec} \\
80^{\circ} \mathrm{C} \text { for } 15 \mathrm{sec}(\mathrm{read}) \\
40 \text { cycles of } \\
95^{\circ} \mathrm{C} \text { for } 15 \mathrm{sec} \\
58^{\circ} \mathrm{C} \text { for } 30 \mathrm{sec} \\
72^{\circ} \mathrm{C} \text { for } 30 \mathrm{sec} \\
80^{\circ} \mathrm{C} \text { for } 15 \mathrm{sec}(\mathrm{read})\end{array}$ & $\begin{array}{l}\text { Alcaligenes } \\
\text { faecalis ATCC } \\
8750\end{array}$ & (Geets et al. 2007) \\
\hline $\begin{array}{l}\text { Bacterial } \\
16 \mathrm{~S} \text { rRNA }\end{array}$ & $\begin{array}{l}\text { 8F (400nM)- } \\
\text { AGAGTTTGATCCTGGCTC } \\
\text { AG } \\
\text { 1492R (400nM)- } \\
\text { GGTTACCTTGTTACGACT } \\
\text { T }\end{array}$ & $\begin{array}{l}94^{\circ} \mathrm{C} \text { for } 120 \mathrm{sec} . \\
30 \text { cycles of } \\
94^{\circ} \mathrm{C} \text { for } 30 \mathrm{sec} \\
47^{\circ} \mathrm{C} \text { for } 60 \mathrm{sec} \\
72^{\circ} \mathrm{C} \text { for } 60 \mathrm{sec} \\
\text { Final extension of } \\
72^{\circ} \mathrm{C} \text { for } 600 \mathrm{sec}\end{array}$ & $\begin{array}{l}\text { Escherichia } \\
\text { coli, } \\
\text { Pseudomonas } \\
\text { stutzeri }\end{array}$ & \\
\hline
\end{tabular}




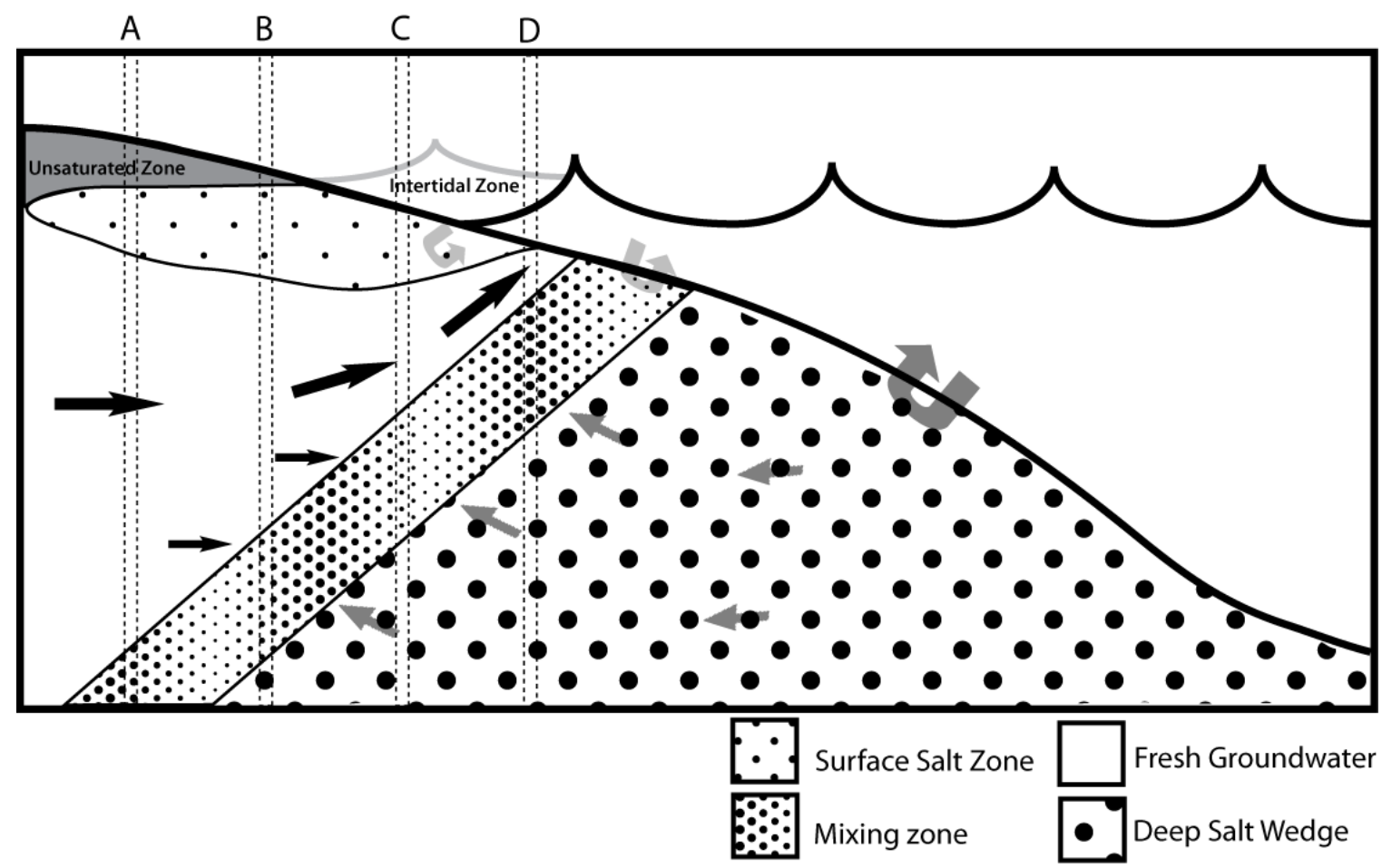

Figure 1. Sampling schematic depicting the relative position of the piezometer locations $(\mathrm{A}, \mathrm{B}, \mathrm{C}, \mathrm{D})$ in relation to the aquifer structure. The aquifer is composed of three distinct water parcels, (1) a surface salt zone (stippled), (2) a fresh groundwater plume (white) and (3) a deep salt wedge (large stipples). The mixing zone between the freshwater and deep salt wedge is noted with a gradient in stippling. Pulse-coring was performed at site B during June 2008. 
A)

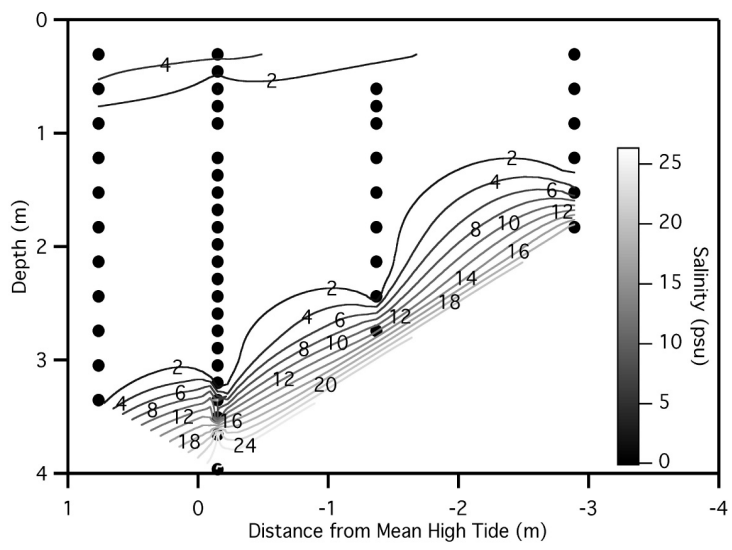

C)

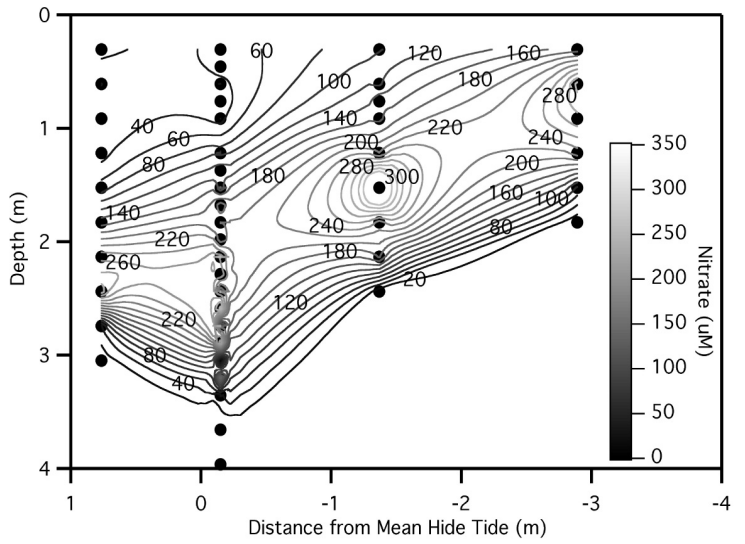

B)

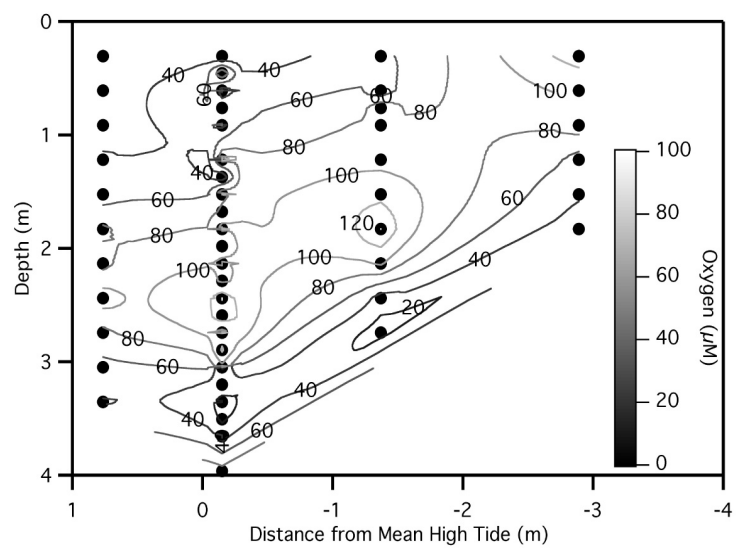

D)

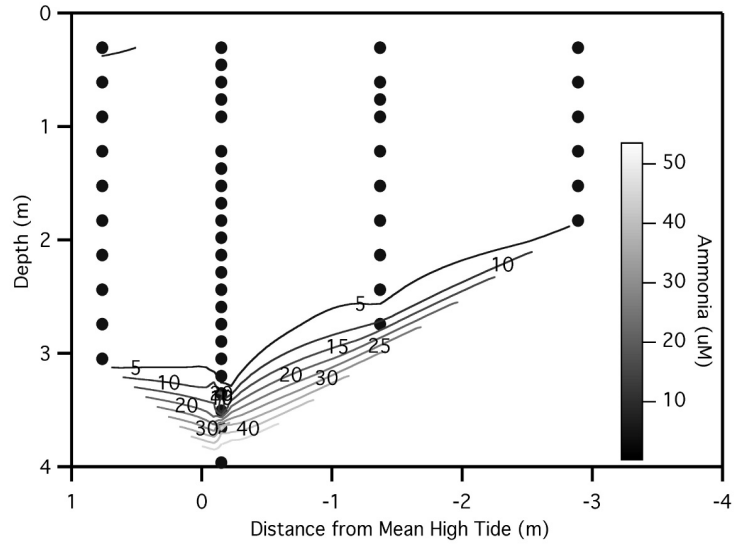

Figure 2. Chemical profiles along a transect normal to the shore line at the head of Waquoit Bay, Cape Cod, MA. Transect moves from on-shore to off, left to right with positive distance above the mean high tide. Black circles represent sampling points along each of the four piezometer locations. Sediment coring was done at station B. A) Salinity is most pronounced in the deep salt wedge and shoals moving off-shore. B) Dissolved oxygen $(\mu \mathrm{M})$ peaks in the fresh groundwater and shoals off-shore. $C)$ Nitrate $(\mu \mathrm{M})$ peaks in the fresh groundwater but is also present in the surface salt zone. Nitrate is absent from the deep salt wedge. D) Ammonium is not observed in the fresh groundwater parcel but routinely found in the deep salt wedge likely due to remineralization of organic carbon or cation exchange. 
A)

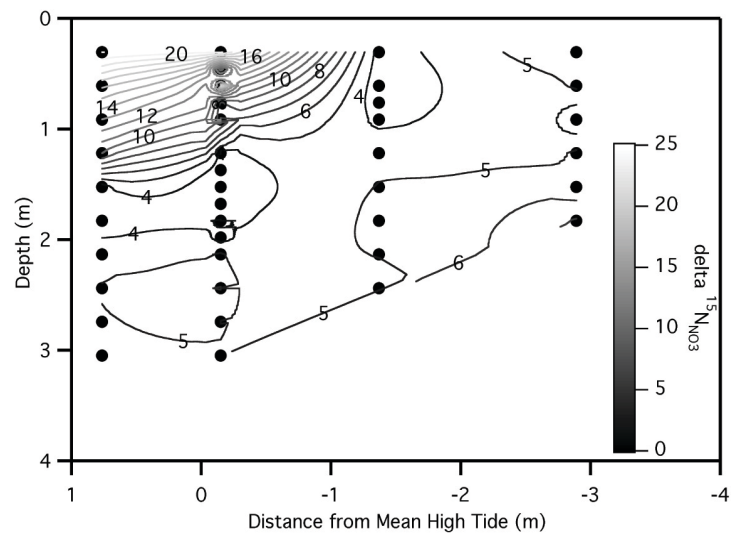

C)

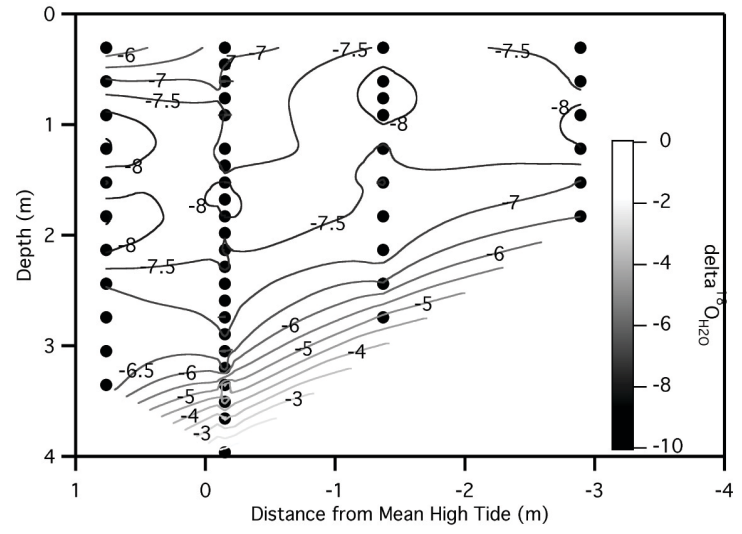

B)

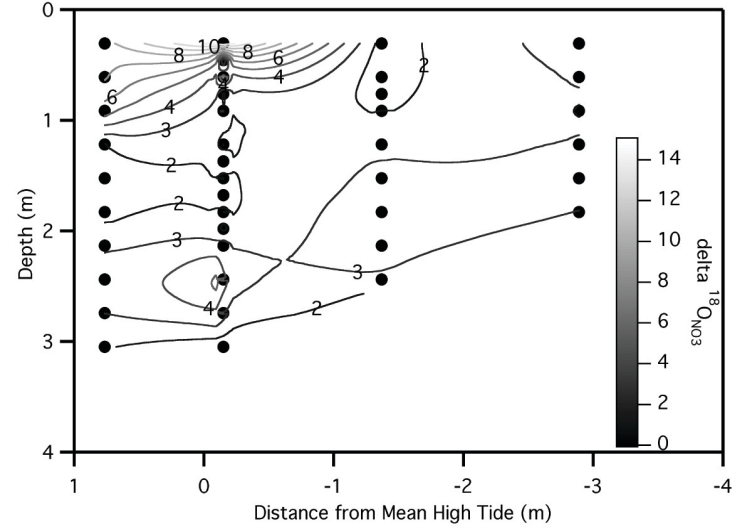

D)

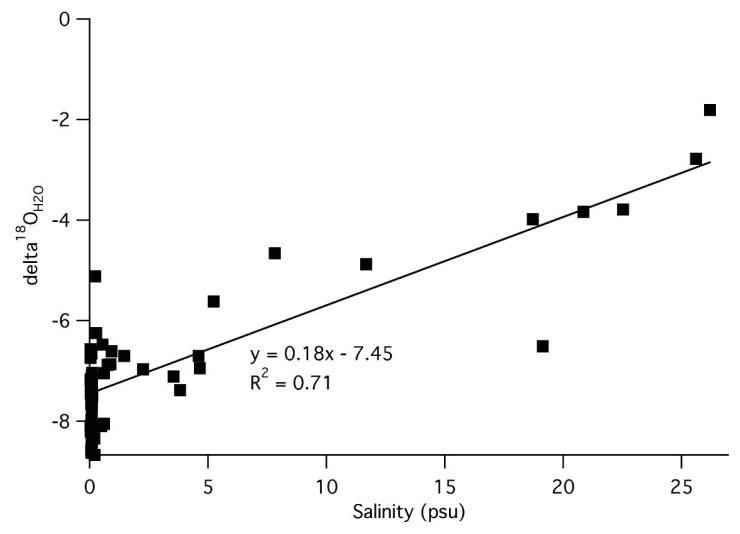

Figure 3. Natural abundance isotope profiles along a transect normal to the shore line at the head of Waquoit Bay, Cape Cod, MA. Transect moves from on-shore to off, left to right with positive distance above the mean high tide. Black circles represent sampling points along each of the four piezometer locations. A) The $\delta^{15} \mathrm{~N}_{\mathrm{NO} 3}$ across the transect reveals low values similar to bay water in the core of the freshwater plume and increasing values in the surface pore water of the two most shoreward piezometers. B) $\delta^{18} \mathrm{O}_{\mathrm{NO} 3}$ reveals a similar distribution as $\mathrm{d}^{15} \mathrm{~N}_{\mathrm{NO} 3}$. C) $\delta^{18} \mathrm{O}_{\mathrm{H} 2 \mathrm{O}}$ is most depleted in the core of the fresh groundwater plume. D) Plotting $\delta^{18} \mathrm{O}_{\mathrm{H} 2 \mathrm{O}}$ against salinity reveals a steady mixing line at all but the lowest values. 


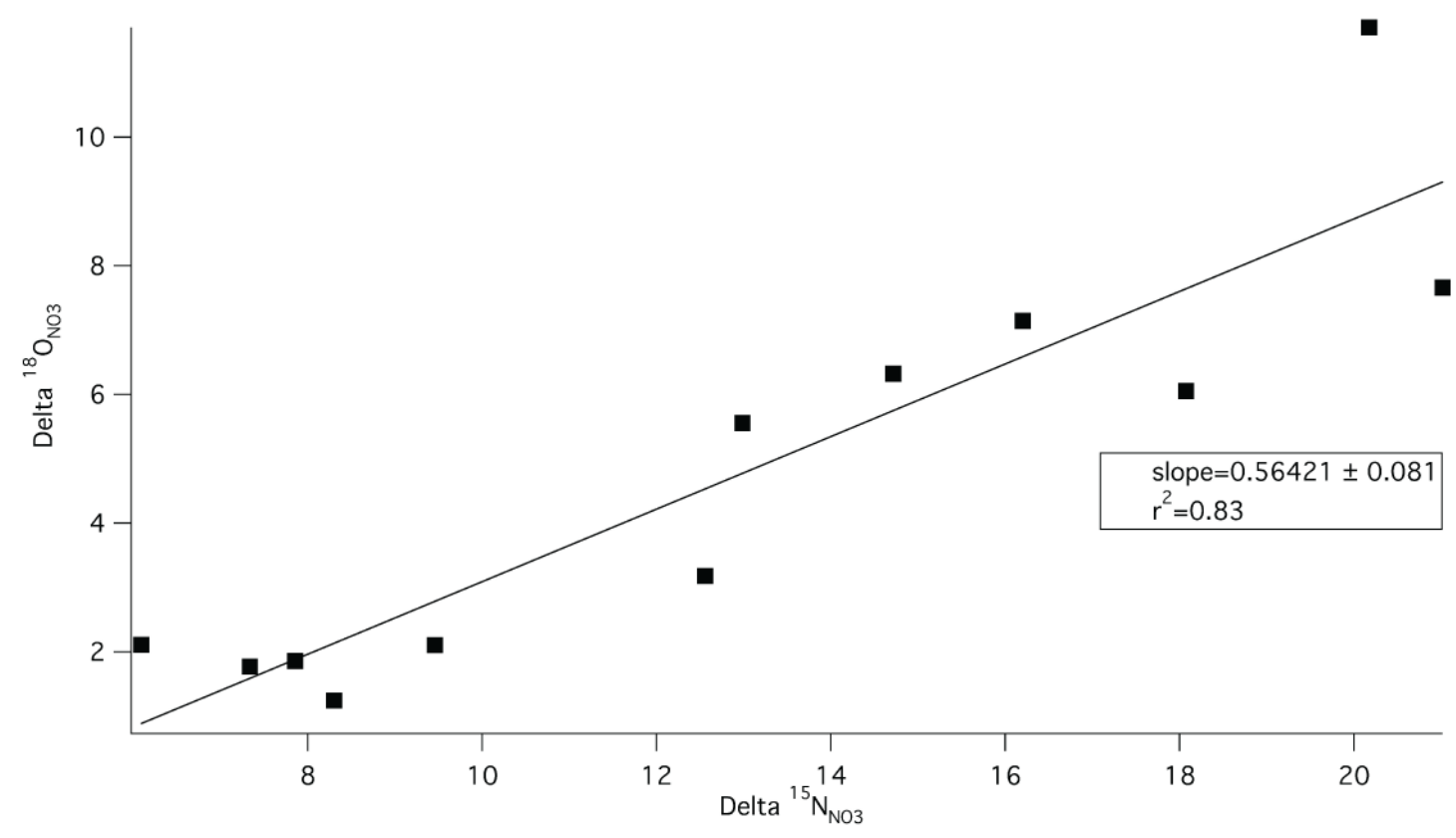

Figure 4. The relationship between $\delta^{15} \mathrm{~N}_{\mathrm{NO} 3}$ and $\delta^{18} \mathrm{O}_{\mathrm{NO} 3}$ in the upper meter of groundwater at Waquoit bay is consistent with previous reports of groundwater denitrification. 


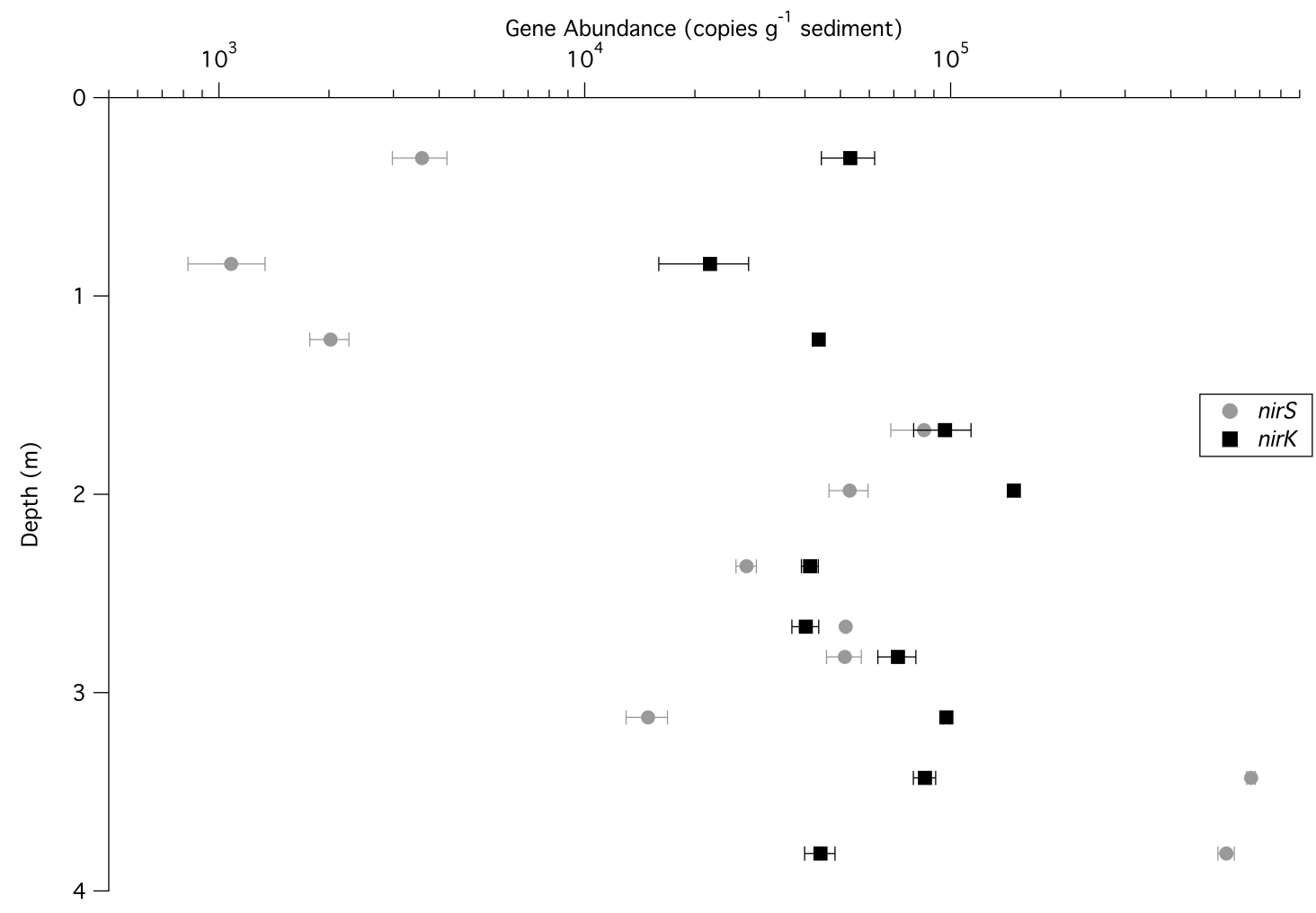

Figure 5. The nitrite reductase occurs in two types, a copper based nirK and a cytochrome based nirS. Abundance of nirS genes (grey circles) increase with depth, peaking at $3.8 \mathrm{~m}$. NirK gene abundance (black squares) varies less than an order of magnitude throughout the core. Error bars represent one standard deviation based on triplicate analysis. 
A

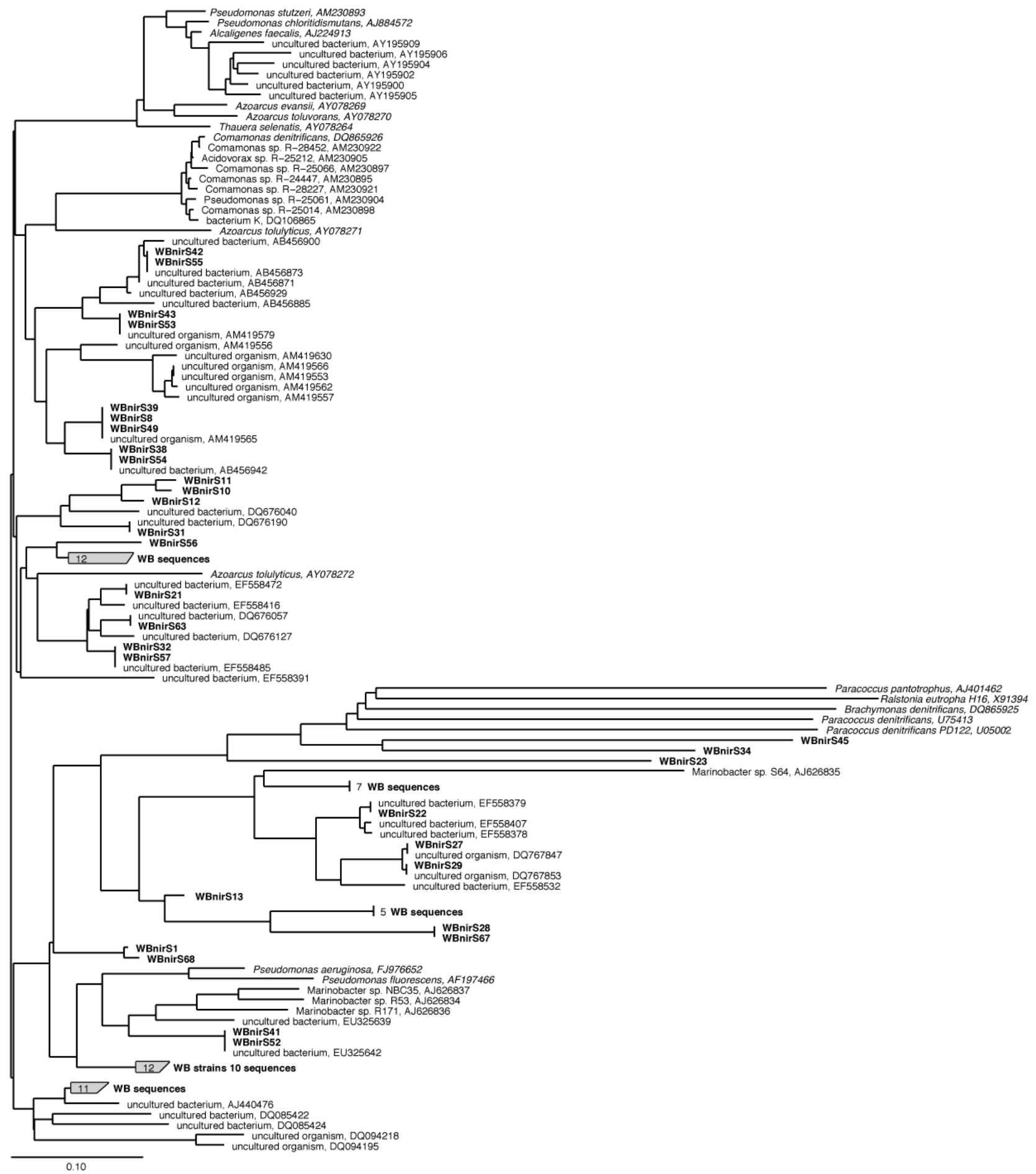


B

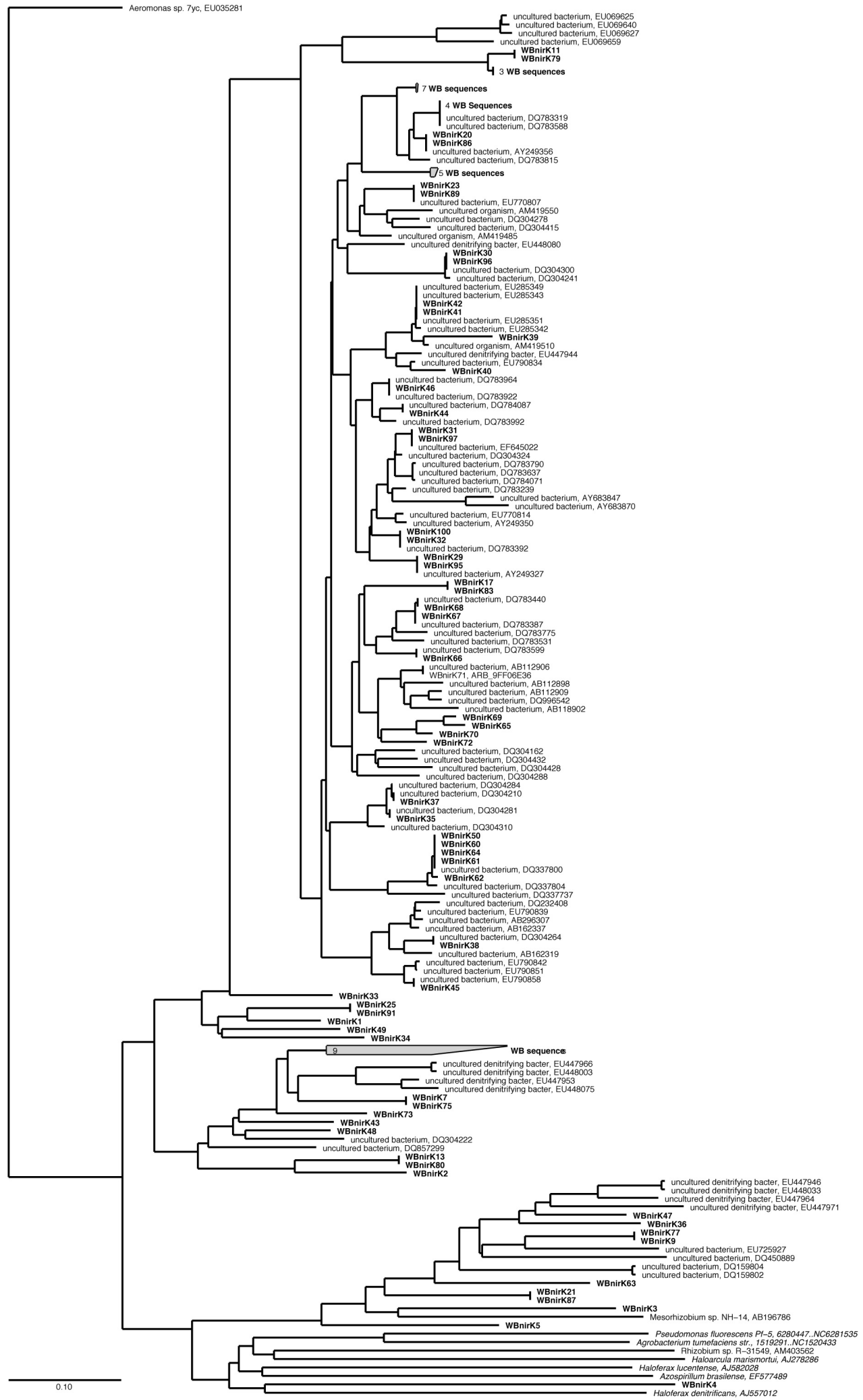


Figure 6. A) Phylogenetic relationship of recovered $\operatorname{nir} S(\mathrm{~A})$ and $\operatorname{nirK}(\mathrm{B})$ sequences to sequences present in Genbank. Sequences were imported in to the ARB phylogenetic software and aligned using the ARB aligner followed by manual editing. Trees were constructed using the neighbor joining function with a conservative mask of $552 \mathrm{bp}$ (nirS) and 427 bp (nirK). Sequences recovered from this study are in bold and known cultures are italicized. 


\section{References}

Aravena, R., M. L. Evans and J. A. Cherry (1993). "Stable Isotopes of Oxygen and Nitrogen in Source Identification of Nitrate from Septic Systems." Ground Water 31(2): 180-186.

Aravena, R. and W. D. Robertsona (1998). "Use of multiple isotope tracers to evaluate denitrification in ground water: Study of nitrate from a large-flux septic system plume." Ground Water 36(6): 975-982.

Bano, N. and J. Hollibaugh (2002). "Phylogenetic composition of bacterioplankton assemblages from the Arctic Ocean." Applied and Environmental Microbiology 68(2): 505-518.

Barnes, R. T., P. A. Raymond and K. L. Casciotti (2008). "Dual isotope analyses indicate efficient processing of atmospheric nitrate by forested waersheds in the northeastern U.S." Biogeochemistry 90: 15-27.

Böttcher, J., O. Strebel, S. Voerkelius and H. Schmidt (1990). "Using isotope fractionation of nitrate-nitrogen and nitrate-oxygen for evaluation of microbial denitrification in a sandy aquifer." Journal of Hydrology 114: 413-424.

Braker, G., A. Fesefeldt and K.-P. Witzel (1998). "Development of PCR Primer Systems for Amplification of Nitrite Reductase Genes (nirK and nirS) To Detect Denitrifying Bacteria in Environmental Samples." Appl. Environ. Microbiol. 64(10): 3769-3775.

Braker, G., J. Zhou, L. Wu, A. H. Devol and J. M. Tiedje (2000). "Nitrite Reductase Genes (nirK and nirS) as Functional Markers To Investigate Diversity of Denitrifying Bacteria in Pacific Northwest Marine Sediment Communities." Applied and Environmental Microbiology 66(5): 2096.

Bremer, C., G. Braker, D. Matthies, A. Reuter, C. Engels and R. Conrad (2007). "Impact of Plant Functional Group, Plant Species, and Sampling Time on the Composition of nirK-Type Denitrifier Communities in Soil." Appl. Environ. Microbiol. 73(21): 6876-6884.

Bricker, S., C. Clement, D. Pirhalla, S. Orlando and D. Farrow (1999). National Estuarine Eutrophication Assessment: effects of nutrient enrichment in the nation's estuaries. N. O. Service, National Oceanic and Atmospheric Administration: 71.

Brodie, E., T. DeSantis, D. Joyner, S. Baek, J. Larsen, G. Andersen, T. Hazen, P. Richardson, D. Herman and T. Tokunaga (2006). "Application of a High-Density Oligonucleotide Microarray Approach To Study Bacterial Population Dynamics during Uranium Reduction and Reoxidation $\dagger$." Applied and Environmental Microbiology 72(9): 6288-6298.

Buchwald, C. and K. L. Casciotti (2010). "Oxygen isotopic exchange and fractionation during bacterial nitrite oxidation." Limnology and Oceanography 55(3): 10641074.

Bugna, G., J. Chanton, J. Cable, W. Burnett and P. Cable (1996). "The importance of groundwater discharge to the methane budgets of nearshore and continental shelf waters of the northeastern Gulf of Mexico." Geochimica et Cosmochimica Acta 60(23): 4735-4746. 
Bull, A. T. and J. E. M. Stach (2007). "Marine actinobacteria: new opportunities for natural product search and discovery." TRENDS in Microbiology 15(11): 491499.

Burnett, W. and H. Dulaiova (2003). "Estimating the dynamics of groundwater input into the coastal zone via continuous radon-222 measurements." Journal of environmental radioactivity 69(1-2): 21-35.

Burnett, W. C., H. Bokuniewicz, M. Huettel, W. S. Moore and M. Taniguchi (2003). "Groundwater and pore water inputs to the coastal zone." Biogeochemistry 66(1 2): 3.

Burns, D. and C. Kendall (2002). "Analysis of delta $15 \mathrm{~N}$ and delta $18 \mathrm{O}$ to differentiate NO3- sources in runoff at two watersheds in the Catskill Mountains of New York." Water Resour. Res 38(5): 1029-1041.

Cai, W., Y. Wang, J. Krest and W. Moore (2003). "The geochemistry of dissolved inorganic carbon in a surficial groundwater aquifer in North Inlet, South Carolina, and the carbon fluxes to the coastal ocean." Geochimica et Cosmochimica Acta 67(4): 631-639.

Casciotti, K., M. McIlvin and C. Buchwald (2010). "Oxygen isotopic exchange and fractionation during bacterial ammonia oxidation." Limnol. Oceanogr 55(2): 753762.

Casciotti, K. L., D. M. Sigman, M. G. Hastings, J. K. Bohlke and A. Hilkert (2002). "Measurement of the Oxygen Isotopic Composition of Nitrate in Seawater and Freshwater Using the Denitrifier Method." Anal. Chem. 74(19): 4905-4912.

Casciotti, K. L., D. M. Sigman and B. B. Ward (2003). "Linking diversity and stable isotope fractionation in ammonia-oxidizing bacteria." Geomicrobiology Journal 20(4): 335-353.

Charette, M. and E. Sholkovitz (2002). "Oxidative precipitation of groundwater-derived ferrous iron in the subterranean estuary of a coastal bay." Geophysical Research Letters 29(10): 1444.

Charette, M. A. and E. R. Sholkovitz (2006). "Trace element cycling in a subterranean estuary: Part 2. Geochemistry of the pore water." Geochimica et Cosmochimica Acta 70(4): 811.

Charette, M. A., E. R. Sholkovitz and C. M. Hansel (2005). "Trace element cycling in a subterranean estuary: Part 1. Geochemistry of the permeable sediments." Geochimica et Cosmochimica Acta 69(8): 2095.

Chou, H.-H. and M. H. Holmes (2001). "DNA sequence quality trimming and vector removal." Bioinformatics 17(12): 1093-1104.

Cox, R. D. (1980). "Determination of nitrate and nitrite at the parts per billion level by chemiluminescence." Analytical Chemistry 52(2): 332-335.

Durka, W., E. Schulze, G. Gebauer and S. Voerkelius (1994). "Effects of forest decline on uptake and leaching of deposited nitrate determined from super (15) $\mathrm{N}$ and super (18) O measurements." Nature 372(6508): 765-767.

Enger, O., H. Nygaard, M. Solberg, G. Schei, J. Nielsen and I. Dundas (1987). "Characterization of Alteromonas denitrificans sp. nov." Int J Syst Bacteriol 37(4): 416-421. 
Ewing, B. and P. Green (1998). Base-calling of automated sequencer traces using Phred. II. Error probabilities, Cold Spring Harbor Lab. 8: 186-194.

Ewing, B., L. Hillier, M. Wendl and P. Green (1998). Base-calling of automated sequencer traces using Phred. I. Accuracy assessment, Cold Spring Harbor Lab. 8: $175-185$.

Fukada, T., K. M. Hiscock and P. F. Dennis (2004). "A dual-isotope approach to the nitrogen hydrochemistry of an urban aquifer." Applied Geochemistry 19(5): 709.

Garside, C. (1982). "A chemiluminescent technique for the determination of nanomolar concentrations of nitrate and nitrite in seawater." Marine Chemistry 11(2): 159167.

Garside, C. (1985). "The vertical distribution of nitrate in open ocean surface water." Deep Sea Research Part A. Oceanographic Research Papers 32(6): 723-732.

Geets, J., M. de Cooman, L. Wittebolle, K. Heylen, B. Vanparys, P. De Vos, W. Verstraete and N. Boon (2007). "Real-time PCR assay for the simultaneous quantification of nitrifying and denitrifying bacteria in activated sludge." Applied Microbiology and Biotechnology 75(1): 211-221.

Gihring, T., D. Moser, L. Lin, M. Davidson, T. Onstott, L. Morgan, M. Milleson, T. Kieft, E. Trimarco and D. Balkwill (2006). "The distribution of microbial taxa in the subsurface water of the Kalahari Shield, South Africa." Geomicrobiology Journal 23(6): 415-430.

Henry, S., E. Baudoin, J. C. Lopez-Gutierrez, F. Martin-Laurent, A. Brauman and L. Philippot (2004). "Quantification of denitrifying bacteria in soils by nirK gene targeted real-time PCR." Journal of Microbiological Methods 59(3): 327-335.

Kasai, Y., H. Kishira, T. Sasaki, K. Syutsubo, K. Watanabe and S. Harayama (2002). "Predominant growth of Alcanivorax strains in oil-contaminated and nutrientsupplemented sea water." Environmental Microbiology 4(3): 141.

Kendall, C. and T. Coplen (2001). "Distribution of oxygen-18 and deuterium in river waters across the United States." Hydrological Processes 15(7): 1363-1393.

Koblížek, M., O. Béjà, R. Bidigare, S. Christensen, B. Benitez-Nelson, C. Vetriani, M. Kolber, P. Falkowski and Z. Kolber (2003). "Isolation and characterization of Erythrobacter sp. strains from the upper ocean." Archives of Microbiology 180(5): 327-338.

Korner, H. and W. G. Zumft (1989). "Expression of denitrification enzymes in response to the dissolved oxygen level and respiratory substrate in continuous culture of Pseudomonas stutzeri." Appl. Environ. Microbiol. 55(7): 1670-1676.

Kroeger, K. D. and M. A. Charette (2008). "Submarine groundwater discharge: nitrogen biogeochemistry of the discharge zone." Limnol. Oceanogr 53(3): 1025-1039.

Kroeger, K. D., P. W. Swarzenski, W. J. Greenwood and C. Reich (2007). "Submarine groundwater discharge to Tampa Bay: Nutrient fluxes and biogeochemistry of the coastal aquifer." Marine Chemistry 104(1-2): 85-97.

Lam, P., G. Lavik, M. M. Jensen, J. van de Vossenberg, M. Schmid, D. Woebken, D. Gutierrez, R. Amann, M. Jetten and M. M. M. Kuypers (2009). "Revising the nitrogen cycle in the Peruvian oxygen minimum zone." Proc Natl Acad Sci USA 106: $4752-4757$. 
Ludwig, W., O. Strunk, R. Westram, L. Richter, H. Meier, A. Buchner, T. Lai, S. Steppi, G. Jobb, W. Förster, I. Brettske, I. Gerber, A. Ginhart, O. Gross, S. Grumann, S. Hermann, R. Jost, A. König, T. Liss, R. Lüßmann, M. May, B. Nonhoff, B. Reichel, R. Strehlow, A. Stamatakis, N. Stuckmann, A. Vilbig, M. Lenke, T. Ludwig, A. Bode and K.-H. Schleifer (2004). "ARB: a software environment for sequence data." Nucleic Acids Res 32(4): 1363-1371.

Mariotti, A., J. Germon, P. Hubert, P. Kaiser, R. Letolle, A. Tardieux and P. Tardieux (1981). "Experimental determination of nitrogen kinetic isotope fractionation: Some principles; illustration for the denitrification and nitrification processes." Plant and Soil 62(3): 413-430.

Mikhailov, V. and E. Ivanova (1995). "Bacteria of the genus Alteromonas: Systematics and physiologically active compounds." RUSS. J. MAR. BIOL./BIOL. MORYA; BIOL. MORYA: 3.

Monza, J., P. Irisarri, P. Diaz, M. Delgado, S. Mesa and E. Bedmar (2006).

"Denitrification ability of rhizobial strains isolated from Lotus sp." Antonie van Leeuwenhoek 89(3): 479-484.

Moore, W. S. (1999). "The subterranean estuary: A reaction zone of ground water and sea water." Marine Chemistry 65: 111-125.

Nielsen, L. P., P. B. Christensen, N. P. Revsbech and J. Sørensen (1990). "Denitrification and oxygen respiration in biofilms studied with a microsensor for nitrous oxide and oxygen." Microbial Ecology 19(1): 63-72.

Nogales, B., K. Timmis, D. Nedwell and A. Osborn (2002). "Detection and Diversity of Expressed Denitrification Genes in Estuarine Sediments after Reverse Transcription-PCR Amplification from mRNA." Applied and Environmental Microbiology 68(10): 5017-5025.

Northup, D., S. Barns, L. Yu, M. Spilde, R. Schelble, K. Dano, L. Crossey, C. Connolly, P. Boston and D. Natvig (2003). "Diverse microbial communities inhabiting ferromanganese deposits in Lechuguilla and Spider Caves." Environmental Microbiology 5(11): 1071.

Nowicki, B., E. Requintina, D. Van Keuren and J. Portnoy (1999). "The role of sediment denitrification in reducing groundwater-derived nitrate inputs to Nauset Marsh Estuary, Cape Cod, Massachusetts." Estuaries and Coasts 22(2): 245-259.

Okada, N., N. Nomura, T. Nakajima-Kambe and H. Uchiyama (2005). "Characterization of the Aerobic Denitrification in Mesorhizobium sp. Strain NH-14 in Comparison with that in Related Rhizobia." Microbes and Environments 20(4): 208-215.

Paerl, H. (1997). "Coastal eutrophication and harmful algal blooms: Importance of atmospheric deposition and groundwater as" new" nitrogen and other nutrient sources." Limnology and Oceanography 42(5): 1154-1165.

Pujalte, M. J., M. Carmen Maci-n, D. R. Arahal and E. Garay (2005). "Stappia alba sp. nov., isolated from Mediterranean oysters." Systematic and Applied Microbiology 28(8): 672-678.

Reed, D., Y. Fujita, M. Delwiche, D. Blackwelder, P. Sheridan, T. Uchida and F. Colwell (2002). "Microbial communities from methane hydrate-bearing deep marine 
sediments in a forearc basin." Applied and Environmental Microbiology 68(8): 3759-3770.

Santoro, A. E., A. B. Boehm and C. A. Francis (2006). "Denitrifier community composition along a nitrate and salinity gradient in a coastal aquifer." Appl. Environ. Microbiol. 72(3): 2102-2109.

Seidman, C. E., K. Struhl, J. Sheen and T. Jessen (2002). Introduction of Plasmid DNA into Cells. Current Protocols in Molecular Biology, John Wiley \& Sons Inc.

Seitzinger, S., J. A. Harrison, J. K. Bohlke, A. F. Bouwman, R. Lowrance, B. Peterson, C. Tobias and G. V. Drecht (2006). "Denitrification across landscapes and waerscapes: a synthesis." Ecological Applications 16(6): 2064-2090.

Seitzinger, S. P. (1988). "Denitrification in Freshwater and Coastal Marine Ecosystems: Ecological and Geochemical Significance." Limnology and Oceanography 33(4): $702-724$.

Sharma, S., M. K. Aneja, J. Mayer, J. C. Munch and M. Schloter (2005). "Diversity of Transcripts of Nitrite Reductase Genes (nirK and nirS) in Rhizospheres of Grain Legumes." Appl. Environ. Microbiol. 71(4): 2001-2007.

Sigman, D. M., K. L. Casciotti, M. Andreani, C. Barford, M. Galanter and J. K. Bohlke (2001). "A Bacterial Method for the Nitrogen Isotopic Analysis of Nitrate in Seawater and Freshwater." Anal. Chem. 73(17): 4145-4153.

Slomp, C. P. and P. Van Cappellen (2004). "Nutrient inputs to the coastal ocean through submarine groundwater discharge: controls and potential impact." Journal of Hydrology(Amsterdam) 295(14): 64-86.

Smith, C. J., D. B. Nedwell, L. F. Dong and A. M. Osborn (2007). "Diversity and abundance of nitrate reductase (narG \& napA), and nitrite reductase (nirS and nrfA) genes and transcripts in estuarine sediments." Appl. Environ. Microbiol.: AEM.02894-06.

Solorzano, L. (1969). "Determination of Ammonia in Natural Waters by the Phenolhypochlorite Method." Limnology and Oceanography 14(5): 799-801.

Spiteri, C., C. Slomp, M. Charette, K. Tuncay and C. Meile (2008). "Flow and nutrient dynamics in a subterranean estuary (Waquoit Bay, MA, USA): field data and reactive transport modeling." Geochimica et Cosmochimica Acta 72(14): 33983412.

Spoelstra, J., S. L. Schiff, R. J. Elgood, R. G. Semkin and D. S. Jeffries (2001). "Tracing the Sources of Exported Nitrate in the Turkey Lakes Watershed Using 15N/14N and 180/16O isotopic ratios." Ecosystems 4(6): 536-544.

Talbot, J. M., K. D. Kroeger, A. Rago, M. C. Allen and M. A. Charette (2003). "Nitrogen flux and speciation through the subterranean estuary of Waquoit Bay, Massachusetts." Biol Bull 205(2): 244-245.

Tang, Y., T. Shigematsu, S. Morimura and K. Kida (2004). "The effects of microaeration on the phylogenetic diversity of microorganisms in a thermophilic anaerobic municipal solid-waste digester." Water Research 38(10): 2537-2550.

Throback, I., K. Enwall, A. Jarvis and S. Hallin (2004). "Reassessing PCR primers targeting nirS, nirK and nosZ genes for community surveys of denitrifying bacteria with DGGE." FEMS Microbiology Ecology 49(3): 401-417. 
Valiela, I., G. Collins, J. Kremer, K. Lajtha, M. Geist, B. Seely, J. Brawley and C. H. Sham (1997). "Nitrogen loading from coastal watersheds to receiving estuaries: New method and applications." Ecological Applications 7(2): 358-380.

Valiela, I., K. Foreman, M. LaMontagne, D. Hersh, J. Costa, P. Peckol, B. DeMeoAndreson, C. D'Avanzo, M. Babione, C.-H. Sham, J. Brawley and K. Lajtha (1992). "Couplings of watersheds and coastal waters: Sources and consequences of nutrient enrichment in Waquoit Bay, Massachusetts." Estuaries 15(4): 443-457.

Valiela, I., M. Geist, M. McClelland and G. Tomasky (2000). "Nitrogen loading from watersheds to estuaries: Verification of the Waquoit Bay Nitrogen Loading Model." Biogeochemistry 49(3): 277.

Ward, B. B. (1996). "Nitrification and denitrification: Probing the nitrogen cycle in aquatic environments." Microbial Ecology 32(3): 247-261.

Weber, C. F. and G. M. King (2007). "Physiological, Ecological, and Phylogenetic Characterization of Stappia, a Marine CO-Oxidizing Bacterial Genus." Appl. Environ. Microbiol. 73(4): 1266-1276.

Yoshida, N. (1988). "15N-depleted N2O as a product of nitrification."

Yoshie, S., N. Noda, S. Tsuneda, A. Hirata and Y. Inamori (2004). "Salinity Decreases Nitrite Reductase Gene Diversity in Denitrifying Bacteria of Wastewater Treatment Systems." Appl. Environ. Microbiol. 70(5): 3152-3157.

Zumft, W. (1992). "The denitrifying prokaryotes." The prokaryotes 1: 554-582.

Zumft, W. G. (1997). "Cell biology and molecular basis of denitrification." Microbiol. Mol. Biol. Rev. 61(4): 533-616. 
Chapter 4: Nitrification in a Coastal Groundwater Aquifer: Roles for both Archaea and Bacteria in a Nitrogen Rich Sediment Column.

\author{
Daniel R. Rogers ${ }^{\dagger *}$, Karen L. Casciotti ${ }^{\dagger}$ \\ ${ }^{\dagger}$ Department of Marine Chemistry and Geochemistry and ${ }^{\dagger}$ MIT/WHOI Joint Program in \\ Chemical Oceanography, Woods Hole Oceanographic Institution, Woods Hole MA \\ 02543. \\ ${ }^{*}$ Corresponding author \\ phone: 508-289-3748 \\ fax: 508-457- 2076 \\ email: drogers@whoi.edu
}




\begin{abstract}
Submarine groundwater discharge can be an important source of nitrogen to coastal waters. However, little is known about the microbial nitrogen cycle in groundwater settings. Previous work has shown the presence three populations of nitrifiers in the Waquoit Bay groundwater system, two different archaeal populations, one in the upper meter and one at the transition between the freshwater and deep salt wedge as well as a bacterial population within the freshwater plume. The aim of the current study is to estimate the potential nitrification rates at three depths in the groundwater system using a ${ }^{15} \mathrm{~N}$-labeled ammonium technique. Allylthiourea (ATU), an inhibitor for bacterial nitrification, was used to differentiate between archaeal and bacterial nitrification activity. The expression of bacterial and archaeal ammonia monooxygenase genes $(a m o A)$ was also followed over the time course of the incubations. Potential nitrification rates in the surface salt zone and freshwater plume were similar to estuarine sediments. Incubations from the surface salt zone contained archaeal amo $A$ expression that was not suppressed in the presence of ATU. This contrasts with the incubations from the freshwater plume where bacterial amo $A$ was expressed but showed sensitivity to ATU. The deep salt wedge contained a population of putative archaeal ammoniaoxidizers, as determined from the presence of archaeal amo $A$ genes; however, evidence of active nitrification was lacking in these deep sediments.
\end{abstract}




\section{Introduction}

Submarine groundwater discharge (SGD), the transport of terrestrial groundwater and recirculated seawater through sediments and into coastal waters, is increasingly recognized as an important route for chemical discharge to the coastal ocean (Moore 1999). Though the global freshwater flux from SGD is small (ca. 6\%, Burnett et al. 2003) compared to riverine water flux, the impact on the local environment may be important due to the large chemical load these waters can carry. For example, with one-third of the world's population living within $100 \mathrm{~km}$ of the coast (Cohen et al. 1997) many groundwater systems carry large, anthropogenically derived, nutrient loads. This nutrient addition to coastal waters, known as eutrophication, has broad deleterious effects on coastal ecosystems including increasing the frequency and duration of harmful algal blooms and expanding regions of hypoxia and anoxia. Nutrient addition also alters local

food webs, degrades sea grass beds, decreases biodiversity, and compromises fin-fish and shellfish populations for human consumption (Valiela et al. 1990; Valiela et al. 1992; Howarth et al. 2002).

The biogeochemical processes that occur within the groundwater system largely control the scale of nutrient input, principally nitrogen, and are therefore important to understand. Unlike surface waters, which flow rapidly over a sediment matrix in communication with the atmosphere, groundwaters typically have slow advection rates flowing through, rather than over, the sediment matrix and are isolated from the atmosphere. Thus the geochemical environment of groundwaters can be very different than that found in riverine settings. This contrast in physical environment can have a 
significant effect on the biogeochemical cycling of nitrogen in groundwaters. In particular, many of the transformations nitrogen can undergo are microbially controlled and sensitive to oxygen availability, which can vary widely in groundwater systems. Therefore, the suite of nitrogen transformations that is possible in a subterranean estuary is very broad.

Oxidation of nitrogen in the environment is observed in the conversion of ammonium through nitrite to nitrate. Specific bacteria (ammonia-oxidizing bacteria, AOB) and archaea (ammonia-oxidizing archaea, AOA) catalyze the oxidation of ammonia for the conservation of energy. A separate group of bacteria, nitrite-oxidizing bacteria, conserve energy through the conversion of nitrite to nitrate. Both the AOB and AOA utilize a (putatively related) protein called ammonia monooxygenase to catalyze the first step in this pathway, converting ammonia to the first intermediate, hydroxylamine. The gene coding for one of the subunits of this enzyme, ammonia monooxygenase subunit A ( $(\mathrm{mo} \mathrm{A})$, has been used as a marker for the presence (Francis et al. 2003; Leininger et al. 2006; Wuchter et al. 2006) and activity of these organisms (Treusch et al. 2005; Lam et al. 2009)

AOB were discovered over one hundred years ago by Winigradsky (Winogradsky 1890) and were, until recently, thought to be the only organisms capable of carrying out this portion of the nitrogen cycle. In the last decade, however, archaea also have been demonstrated to participate in ammonia oxidation, first from molecular evidence from various environments (Venter et al. 2004; Francis et al. 2005; Treusch et al. 2005) followed by further genomic evidence of carbon dioxide fixation and ammonia-oxidation 
pathways (Hallam et al. 2006) and activity in cultured representatives (Konneke et al. 2005; Santoro et al. 2008). AOB and AOA have been found to co-occur in many environments, presumably competing for the ammonia substrate. It is still unclear what environment factor(s) may favor one population of the other. Possible roles for oxygen tension (Santoro et al. 2008), carbon concentration (Hallam et al. 2006), salinity (Francis et al. 2005; Caffrey et al. 2007), $\mathrm{pH}$ (de la Torre et al. 2008) and differences in ammonium concentration (Martens-Habbena et al. 2009) have all been put forth as key environmental factors controlling the balance between AOBs and AOAs.

Here we combine molecular techniques to determine which genes are present and expressed with isotope tracer incubations to build our knowledge of the players and processes active in a groundwater system and how their activity may alter the input of nitrogen into the coastal waters.

\section{Methods}

\section{Sample Collection}

Groundwater samples were collected on the ebbing tide using a stainless steal piezometer equipped with a "Retract-a-tip" (AMS, Idaho) with a vertical resolution of 0.15 to $0.30 \mathrm{~m}$. The tubing was flushed with at least one liter of pore water (more than 6fold flushing of tubing volume) before measuring $\mathrm{pH}$, redox potential, dissolved oxygen, salinity and temperature using a YSI 600R multi-probe (Charette and Sholkovitz 2002). Oxygen, $\mathrm{pH}$, and redox sensors were calibrated against standard solutions following the manufacturers protocols prior to deployment in the field. Porewater from from target 
depths, as guided by previous molecular studies (Chapter 2), was collected in $4 \mathrm{~L}$ cubitainers and capped while overflowing to minimize alteration of the in situ oxygen concentrations.

After pore water sampling, sediment was collected near low-tide for nitrification rate measurements from within $0.5 \mathrm{~m}$ of the piezometer, using a hand-operated bailerboring auger (Eijkelkamp, The Netherlands). The interfaces between the shallow salt zone/fresh groundwater $(\sim 0.6 \mathrm{~m})$ and the fresh groundwater/deep salt zone $(\sim 4 \mathrm{~m})$ were targeted, as well as the center of the groundwater plume $(2 \mathrm{~m})$.

\section{Nutrient measurement}

Samples were collected for dissolved inorganic nitrogen analyses $\left(\mathrm{NO}_{3}{ }^{-} \mathrm{NO}_{2}{ }^{-}\right.$, $\mathrm{NH}_{4}{ }^{+}$), filtered through a $0.2 \mu \mathrm{m}$ pore-size Sterivex filter and frozen. Nutrient samples were frozen until analysis. Nitrite, nitrate and ammonium were determined using a Lachet QuickChem 8000 continuous flow injection system at the WHOI Nutrient Analytical Facility.

\section{${ }^{15} \mathrm{~N}$-Ammonium Tracer Experiment}

In September 2009 a pulse-core, reaching a depth of $4 \mathrm{~m}$, was recovered from near piezometer B (Figure 1). Three depths $(0.6,2$ and $4 \mathrm{~m})$ were targeted based on previous observations of microbial populations within and the prevailing groundwater chemistry of the aquifer (Chapter 2). Groundwater from each of these depths was collected using a stainless steel piezometer, filtered $(0.2 \mu \mathrm{m})$ and amended with ${ }^{15} \mathrm{~N}$ - 
labeled ammonium $\left({ }^{15} \mathrm{NH}_{4}{ }^{+}, 99.8\right.$ atom $\%, 50 \mu \mathrm{M}$ final concentration) or ${ }^{15} \mathrm{~N}$-labeled ammonium plus allylthiourea (ATU, $50 \mu \mathrm{M}$ final concentration). Incubations were done in triplicate and contain approximately $100 \mathrm{~g}$ sediment (quantified post-incubation) in a $160 \mathrm{~mL}$ glass serum bottle with the remaining volume filled with the amended water from the same depth. Oxygen concentrations in the collected water were determined using the YSI meter prior to ammonium addition. Incubations were stored at $12{ }^{\circ} \mathrm{C}$ and shaken continually (ca. $100 \mathrm{rpm}$ ) during the course of the experiment. Incubations were destructively sampled in triplicate at $24 \mathrm{hr}$ intervals up to $96 \mathrm{hr}$. Nutrient concentration and isotope $\left(\mathrm{NO}_{2}{ }^{-}\right.$and $\mathrm{NO}_{3}{ }^{-}$at every time point, $\mathrm{NH}_{4}{ }^{+}$initial atom \%) samples, taken in separate $20 \mathrm{~mL}$ aliquots ( $200 \mathrm{~mL}$ for initial $\mathrm{NH}_{4}{ }^{+}$), were filter through a $0.2 \mu \mathrm{m}$ syringe filter (Millipore) into and HDPE bottle and frozen $\left(-20^{\circ} \mathrm{C}\right)$ until analysis. Sediment was also collected and frozen $\left(-80^{\circ} \mathrm{C}\right)$ for DNA $(2 \mathrm{~g})$ and RNA $(10 \mathrm{~g})$ extraction and subsequent molecular analysis (see below).

\section{Isotopic Analysis}

$\delta^{15} \mathrm{~N}$ of the initial ammonium pool was measured in the ammonia-oxidation experiments using the ammonia diffusion method (Sigman et al. 1997; Holmes et al. 1998). In this procedure, ammonia is diffused from a $100 \mathrm{~mL}$ sample and trapped on precombusted and acidified glass fiber filter (GF-D, Millipore) that is encapsulated between two Teflon membranes (Millipore). After 14 days of diffusion on a shaking (ca. 100 rpm), $60{ }^{\circ} \mathrm{C}$ incubator the filter was dried and packed into a tin cup and analyzed by combustion on a PDZ Europa ANCA-GSL elemental analyzer interfaced to a PDZ 
Europa 20-20 isotope ratio mass spectrometer (Sercon Ltd., Cheshire, UK) by the University of California at Davis, Stable Isotope Facility (UCDavis-SIF). Standards were made from dilutions a $400 \mu \mathrm{M}, 99.5$-atom $\% \mathrm{NH}_{4}{ }^{+}$(Cambridge Isotope Laboratories) with a $400 \mu \mathrm{M}$ stock $\mathrm{NH}_{4}{ }^{+}$(Thermo-Fisher) to make additional stocks of 75, 50 and 25atom $\%$. Standards $(12.5 \mathrm{~mL})$ were diluted with $\mathrm{DI}(87.5 \mathrm{~mL})$ for diffusion and trapping with the sample set. Standards and samples were run using $5 \mu$ mols $\mathrm{NH}_{4}{ }^{+}$.

$\delta^{15} \mathrm{~N}$ of the nitrite plus nitrate pools was analyzed following reduction to nitrous oxide for $\mathrm{d}^{15} \mathrm{~N}$ analysis using the denitrifier method (Sigman et al. 2001). However, nitrite was commonly present at insufficient concentrations (rarely higher than $1 \mu \mathrm{M}$ ) for isotopic analysis. The nitrous oxide produced by these methods was analyzed on a PDZ Europa 20-20 Isotope Ratio Mass Spectrometer at the UCDavis-SIF. Standards were made by equimolar $(5 \mathrm{mM})$ dilutions of labeled stocks with natural abundance nitrate (Thermo-Fisher, ACS grade) resulting in standards $98.5,75,50,25$-atom $\%{ }^{15} \mathrm{~N}$. These 5 $\mathrm{mM}$ stocks were diluted $1 \mathrm{~mL}$ into $99 \mathrm{~mL}$ of DI to make $50 \mu \mathrm{M}$ working solutions. Working solutions ( $400 \mu \mathrm{L})$ were injected into purged denitrifier cultures to generate 10 nmol of $\mathrm{N}_{2} \mathrm{O}$ gas. All samples and standards were run at $20 \mathrm{nmols} \mathrm{N}$.

\section{Rate Calculations}

Nitrification rate calculations based on traditional concentration measurements are sensitive to processes that consume nitrate, thus measuring a net rate. The advantage of using the tracer technique to calculate nitrification rates is that the technique is not as sensitive to consumption processes because despite possible isotopic fractionation, these 
processes do not significantly alter the ${ }^{15} \mathrm{~N}$ atom percent of nitrogen pool at tracer levels. Processes such as denitrification or ammonium adsorption to sediments have an isotope effect in the per mil range, which is much smaller than the percent level change observed in the transfer of label-N between the ammonium and nitrate pools. Therefore, the ratio of ${ }^{15} \mathrm{~N} /{ }^{14} \mathrm{~N}$ in nitrate can be used to calculate the nitrification rate. The ratio, ${ }^{15} \mathrm{~N} /{ }^{14} \mathrm{~N}$, is calculated from atom $\%$ by:

$$
A t \%=\left[\frac{\frac{{ }^{15} N}{14} N}{\frac{14 N}{14} N+\frac{15}{14} N}\right] * 100
$$

Where ${ }^{15} \mathrm{~N}$ and ${ }^{14} \mathrm{~N}$ are the concentrations of heavy and light $\mathrm{N}$ isotopes. These ratios can be used to calculate the flux of $\mathrm{N}$ from the labeled ammonium pool to the nitrate pool by:

$$
\frac{\left[{ }^{15} \mathrm{NO}_{3}\right]}{\left[{ }^{14} \mathrm{NO}_{3}\right]}(t)=\frac{\left[{ }^{15} \mathrm{NO}_{3}\right]_{0} e^{\frac{-k t}{\alpha}}+\frac{F_{N i t}\left(\frac{A t \%_{N H} 4+}{100}\right)}{\frac{k}{\alpha}}\left(1-e^{\frac{-k t}{\alpha}}\right)}{\left[{ }^{14} \mathrm{NO}_{3}\right]_{0} e^{-k t}+\frac{F_{N i t}\left(1-\frac{A t \%_{N H 4+}}{100}\right)}{k}\left(1-e^{-k t}\right)}
$$

Where ${ }^{15} \mathrm{~N}_{0}$ and ${ }^{14} \mathrm{~N}_{0}$ are the initial concentrations of labeled and unlabeled nitrate, $\mathrm{F}_{\mathrm{Nit}}$ is the flux of $\mathrm{N}$ from the ammonium pool into the nitrate pool. At $\% \mathrm{NH}_{4}$ is the atom percent ${ }^{15} \mathrm{~N}$ in the ammonium pool and is assumed to be stable (99.5-atom \%) over the course of the experiment (i.e. ammonium regeneration from other unlabeled sources is not significant). $k$ denotes the first-order rate constant for the uptake of ${ }^{14} \mathrm{~N}$-containing nitrate, and $\alpha=1.005$ is the ratio of rate constants $\left({ }^{14} k /{ }^{15} k\right)$ for consumption of unlabeled and labeled nitrate (Sigman et al. 1999). Equation 1 was used to calculate ${ }^{15} \mathrm{~N} /{ }^{14} \mathrm{~N}$ for 
each sample. Equation 2 was used to fit the ${ }^{15} \mathrm{~N} /{ }^{14} \mathrm{~N}$ data using Igor Pro (Wavemetrics) solving for $\mathrm{F}_{\mathrm{Nit}}$ and $k$. Initial values for $\mathrm{F}_{\mathrm{Nit}}$ and $k$ were between 1 and $0.001 \mu \mathrm{mol} \mathrm{L}^{-1}$ day ${ }^{1}$ and 0.1 and $0.000001 \mathrm{day}^{-1}$, respectively. Fit sensitivity to the initial guess of each parameter was tested by holding one variable at a best guess and varying the intial value of the second variable over many orders of magnitude $(1,0.1,0.001$ etc.) until the fit degraded. Rates $\left(\mathrm{F}_{\mathrm{Nit}}\right)$ in from the model fit, in moles $\mathrm{L}^{-1} \mathrm{hr}^{-1}$, were converted to moles $\mathrm{g}^{-1}$ day ${ }^{-1}$ by multiplying by the volume of water in the slurry incubation and normalizing to the dry weight of the sediment.

\section{Molecular Techniques}

DNA was extracted from $1 \mathrm{~g}$ (wet weight) of sediment using lysozyme and proteinase $\mathrm{K}$ digestions followed by physical disruption by successive freeze-thaw cycles and phenol:chloroform:isoamyl extraction (Edwards et al. 2000). Extracted DNA was precipitated using isopropyl alcohol and $3 \mathrm{M}$ sodium acetate with final resuspension in 50 $\mu \mathrm{L}$ of nuclease-free water or Tris-EDTA buffer (TE). The extracts were quantified at 260 nm using a Nanodrop spectrophotometer (Thermo-Fisher Scientific) and diluted using nuclease-free water to appropriate concentrations for amplification and quantification by polymerase chain reaction (PCR) based methods (see below).

RNA was isolated from $2 \mathrm{~g}$ of sediment using the PowerSoil Total RNA Isolation kit (MoBio, USA). Extracts were treated with RQ1 RNase free DNase (Promega) to remove DNA. cDNA was constructed using specific antisense primers (1541R for 16S rRNA, and the antisense primer for the functional genes, Table 1) and the SuperScript III 
First-Strand Synthesis System (Invitrogen) following the manufacturer's instructions. Samples without the reverse transcription were used as negative controls.

Quantitative RT-PCR (qRT-PCR) was employed to determine the gene transcript copy numbers of bacterial and archaeal 16S rRNA and ammonia monooxygenase subunit A $(a m o A)$. cDNA was constructed as detailed above and quantified spectrophotometrically using a Nanodrop spectrophotometer (Thermo-Fisher). The cDNA samples were diluted to $100 \mathrm{ng} \mu \mathrm{L}^{-1}$ and amplified using an iCycler thermocycler (Bio-Rad, Hercules, CA) and a cocktail consisting of $1 \mathrm{X}$ colorless master mix (Promega, Madison, WI), $10 \mathrm{nM}$ dNTPs (Promega), 0.5 X SBYR-Green I (Invitrogen, Carlsbad $\mathrm{CA}$ ), $20 \mathrm{nM}$ fluorescein (Sigma), 1-3 $\mathrm{mM} \mathrm{MgCl} 2$ (Promega), forward and reverse primers (300-1000 nM; Table 1) and 1.25 units of GoTaq Flexi DNA polymerase (Promega). All amplifications used optimized magnesium concentrations and thermal programs using (Table 1) and had efficiencies ranging from $91-111 \%$ for all reactions resulting in linear standard curves $\left(\mathrm{r}^{2}=0.90-0.99\right)$. Standard curves were constructed from serial dilutions ( $10^{7}$ to $10^{1}$ copies $\mu \mathrm{L}^{-1}$ plus a water blank) of linearized p-Gem T-Easy plasmids (Promega) containing inserts of the functional gene of interest (Table 1). Plasmids $(0.5$ $\mu \mathrm{g} \mu \mathrm{L}^{-1}$ ) were linearized by digestion with the EcoRI (New England Biolabs) restriction enzyme in the supplied buffer $\left(2 \mathrm{hr}\right.$ at $37{ }^{\circ} \mathrm{C}$, heat inactivation $20 \mathrm{~min}$. at $\left.65^{\circ} \mathrm{C}\right)$. Restriction digests were cleaned using the SV Wizard PCR purification kit (Promega), eluted in $30 \mu \mathrm{L}$ ) and quantified using a Nanodrop spectrophotometer (Thermo-Fisher). Melt curves were performed on all reactions to confirm specificity. 


\section{Results}

\section{Field Chemistry}

The groundwater profiles from the field effort confirmed the geochemical context of the system, detailed in previous reports (Chapter 2 and 3). In short, the shallow groundwater system is composed of three different parcels of water and the interfaces between them. 1) The surface parcel extends to about $1 \mathrm{~m}$ in depth and is brackish (salinity less than 5), being composed of a mixture of groundwater and seawater from overtopping of the bay water. Oxygen and nitrate are present in concentrations ranging from 30 to $90 \mu \mathrm{M} \mathrm{O}_{2}$ and 0 to $30 \mu \mathrm{M} \mathrm{NO}_{3}{ }^{-}$with the highest concentration occurring in the deeper portions of the parcel. 2) In the fresh groundwater plume, nitrate and oxygen rise to maxima (97.5 and $156 \mu \mathrm{M}$ respectively) before decreasing approaching the deep salt wedge. 3) The deep salt wedge is composed of recirculated seawater and is high in $\mathrm{NH}_{4}{ }^{+}$but low in $\mathrm{O}_{2}$ and $\mathrm{NO}_{3}{ }^{-}$(Figure 1$)$.

\section{${ }^{15} \mathrm{~N}$-Ammonium Incubations}

Sediment from three depths $(0.6 \mathrm{~m}, 2 \mathrm{~m}$, and $4 \mathrm{~m})$ was incubated in a $12{ }^{\circ} \mathrm{C}$ shaker amended with ${ }^{15} \mathrm{~N}$-labeled ammonium with and without allylthiourea (ATU), an inhibitor of bacterial ammonia-oxidation (Hooper and Terry 1973). The shallow sediments from $0.6 \mathrm{~m}$ depth showed a linear decrease of ammonium concentration (ca. 5 $\mu \mathrm{M}$ ) over 4 days while nitrate concentration increased by $3 \mu \mathrm{M}$ (Figure 2 ). The loss of labeled ammonium was accompanied by an increase in the ${ }^{15} \mathrm{~N}$-labeling of the nitrate pool up to 33 -atom $\%$. This increase in isotopic value is consistent with the observed 
increase in the nitrate pool resulting from nitrification of the labeled ammonium pool. The nitrite pool was negligible throughout the experiment. Similar patterns were observed in the ATU treatment, with approximately $10 \mu \mathrm{M}$ of ammonium consumed and $3 \mu \mathrm{M}$ nitrate produced while the ${ }^{15} \mathrm{~N}$-labeling of the nitrate pool increased to ca. 30 -atom $\%$. Nitrification rates were calculated as $0.019 \pm 0.006 \mu \mathrm{mol} \mathrm{L}^{-1} \mathrm{hr}^{-1}$ or $456 \mathrm{pmol} \mathrm{g}^{-1}$ sediment day ${ }^{-1}$ given the $100 \mathrm{~mL}$ aqueous and $100 \mathrm{~g}$ sediment volumes for incubation (Figure 5). This calculation was not sensitive to changes in consumption rates ( $k$ in equation 2) over seven orders of magnitude start values (10 to $\left.1 \times 10^{-5}\right)$. A linear fit was also tested yielding a rate $370 \mathrm{pmol} \mathrm{g}^{-1}$ sediment day ${ }^{-1}$. Nitrification rates in the presence of ATU reached $0.018 \pm 0.001 \mu \mathrm{mol} \mathrm{L}^{-1} \mathrm{hr}^{-1}$ or $432 \mathrm{pmol} \mathrm{g}^{-1}$ sediment day ${ }^{-1}\left(218 \mathrm{pmol} \mathrm{g}^{-1}\right.$ sediment day ${ }^{-1}$, linear fit). Published $\mathrm{N}$-flux rates from the environment are often reported in $\mathrm{mol} \mathrm{m}^{-2}$ time $\mathrm{e}^{-1}$. Therefore to compare these area-normalized estimates to our volume derived estimates some assumptions must be made. First to convert from an area to a volume we calculate a diffusion length using Fick's law:

$$
L=\sqrt{D t}
$$

where $\mathrm{D}$ is the diffusion coefficient and $\mathrm{t}$ is time. This calculation yields a diffusion length of $1.59 \mathrm{~cm} \mathrm{day}^{-1}$ for nitrate in a $12{ }^{\circ} \mathrm{C}$ seawater solution. Converting from a volume to weight of sediment requires an assumption for the sediment density $\left(2.2 \mathrm{~g} \mathrm{~mL}^{-}\right.$ $\left.{ }^{1}\right)$ and the porosity (0.9).

The $2 \mathrm{~m}$ incubations showed a loss of ammonium (ca. $9 \mu \mathrm{M}$ ) and production of nitrate (ca. $7 \mu \mathrm{M}$ ). This increase in nitrate was associated with a corresponding increase in ${ }^{15} \mathrm{~N}$ up to 29 -atom $\%$, an increase that only accounts for ca. $4 \mu \mathrm{M}$ of the observed 
increase assuming all $\mathrm{N}$ originates in the labeled ammonium pool (Figure 3). Unlike the shallow incubations, the $2 \mathrm{~m}$ incubation with ATU showed only an initial loss of ammonium in the first $24 \mathrm{hr}(\mathrm{ca} .3 \mu \mathrm{M})$ and remained stable throughout the remainder of the incubation. Nitrate increased by ca. $4 \mu \mathrm{M}$ in the first $24 \mathrm{hr}$ and remained stable thereafter (ca. $10 \mu \mathrm{M}$ ). The isotopic signature of the nitrate pool increased only slightly during the incubation from $<1$-atom $\%$ to 2.8 -atom $\%$. This increase in ${ }^{15} \mathrm{~N}$ accounts for $0.2 \mu \mathrm{M}$ transfer of $\mathrm{N}$ from the ammonium to nitrate pools. Nitrification rates at this depth were calculated as $0.016 \pm 0.009 \mathrm{nmol} \mathrm{L}^{-1} \mathrm{hr}^{-1}$ or $384 \mathrm{pmol} \mathrm{g}^{-2}$ day $^{-1}\left(327 \mathrm{pmol} \mathrm{g}^{-1}\right.$ sediment day ${ }^{-1}$, linear fit). The nitrification rate in the ATU addition $0.002 \pm 0.0007 \mathrm{nmol}$ $\mathrm{L}^{-1} \mathrm{hr}^{-1}$ or $22 \mathrm{pmol} \mathrm{g}^{-2}$ day $^{-1}$ (22 $\mathrm{pmol} \mathrm{g}^{-1}$ sediment day ${ }^{-1}$, linear fit).

The $4 \mathrm{~m}$ tracer incubation revealed a different chemical pattern than the two shallower incubations. Ammonium, at this depth, decreased by ca. $2 \mu \mathrm{M}$ over the first 24 hr then remained steady for the duration. Nitrate increased by ca. $2 \mu \mathrm{M}$ over the first 24 hr remaining at ca. $4 \mu \mathrm{M}$ for the rest of the time course. This increase in nitrate was not associated with an increase in ${ }^{15} \mathrm{~N}$-atom $\%$ of the nitrate pool. In fact, the ${ }^{15} \mathrm{~N}$-atom $\%$ of the nitrate pool at this depth was less 1 -atom $\%$ for the duration of the experiment.

\section{Gene Expression}

Quantitative RT-PCR was used to determine the expression level of specific functional genes (bacterial $a m o A$ or archaeal $a m o A$ ) as well as bacterial and archaeal $16 \mathrm{~S}$ rRNA genes. mRNA was extracted from the sediment and (reverse) transcribed into cDNA for each incubation in the ${ }^{15} \mathrm{NH}_{4}{ }^{+}$tracer experiment. It must be noted that our 
results will be discussed as relative changes in transcript abundance. Normalization of mRNA expression is challenging (Bustin 2000) and some authors ignore normalization entirely in environmental studies (eg. Lam et al. 2009). Typically, mRNA expression is normalized to expression levels of a gene or suite of genes that is continually expressed at a constant level without sensitivity to culture conditions, such genes are commonly called housekeeping genes. Unfortunately, choosing an appropriate housekeeping gene in an environmental setting, as opposed to a pure culture or tissue culture, is difficult. We initially amplified the rRNA genes with the idea that these genes, which can constitute $85-90 \%$ of the total cellular mRNA (Bustin 2000), may provide an appropriate basis for normalization. Unfortunately, 16S rRNA transcripts were not constant over the course of the incubation (Figure 2, 3, 4), though total RNA yield from extractions were relatively constant. The changing abundance of $16 \mathrm{~S}$ rRNA transcripts may be due to the disruption of sampling (a bottle effect) or the simulation of cells through the addition of substrate $\left(\mathrm{NH}_{4}{ }^{+}\right)$. Therefore, the patterns discussed below are internally comparable as relative abundance but extrapolation to other environments or other experiments is not advisable.

The $0.6 \mathrm{~m}$ incubations showed a nearly 3 -fold increase in archaeal and bacterial 16S cDNA abundance (Figure 2). The archaeal 16S cDNA increased over the first $24 \mathrm{hr}$ of the experiment from $1.4 \times 10^{6}$ to $4.9 \times 10^{6}$ copies $^{-1}$, and remained elevated throughout the remainder of the time course. Bacterial 16S cDNA showed a similar increase from $1.6 \times 10^{6}$ to $4.6 \times 10^{6}$ copies $\mathrm{g}^{-1}$ by $72 \mathrm{hr}$. Archaeal amoA cDNA increased in the first $24 \mathrm{hr}$, from $9.1 \times 10^{3}$ to $5.4 \times 10^{5}$ copies $\mathrm{g}^{-1}$, then steadily decreased over the remainder of the incubation. Bacterial amoA cDNA displayed a similar pattern, 
increasing from $2.3 \times 10^{3}$ to $9.4 \times 10^{4}$ copies $\mathrm{g}^{-1}$ within $24 \mathrm{hr}$, 5-fold lower than the archaeal gene. Addition of the ATU inhibitor resulted in little change in the expression pattern of these genes. Archaeal 16S rRNA and amoA cDNA abundance was not affected by the presence of ATU. Notably, the bacterial 16S rRNA cDNA maintained levels about half of the uninhibited experiment. Likewise, bacterial amo $A$ expression in the ammonium plus ATU incubations remained less than $5 \times 10^{3}$ copies $\mathrm{g}^{-1}$ throughout the time course.

The incubations from $2 \mathrm{~m}$ revealed a different expression pattern than the shallow incubations (Figure 3). Bacterial 16S rRNA cDNA abundance ranged from $1.4 \times 10^{6}$ to $3.9 \times 10^{6}$ copies $\mathrm{g}^{-1}$. Archaeal $16 \mathrm{~S}$ rRNA cDNA abundance showed a similar range, $1.3 \mathrm{x}$ $10^{6}$ to $3.0 \times 10^{6}$ copies $\mathrm{g}^{-1}$. Bacterial amo $A$ cDNA ranged from $4.3 \times 10^{2}$ to $6 \times 10^{5}$ copies $\mathrm{g}^{-1}$, peaking at $48 \mathrm{hr}$ before decreasing to $1.2 \times 10^{5}$ copies $\mathrm{g}^{-1}$ by $96 \mathrm{hr}$. Archaeal amoA abundance was not as dynamic as its bacterial counterpart, ranging $1.4 \times 10^{2}$ to $3.2 \times 10^{2}$ copies $\mathrm{g}^{-1}$. In the presence of ATU, bacterial 16S rRNA cDNA abundance ranges from $9.1 \times 10^{5}$ to $5.0 \times 10^{6}$ copies $\mathrm{g}^{-1}$ but tends to decrease over the course of the experiment. Archaeal 16S rRNA cDNA abundance increases from $1.4 \times 10^{6}$ to $4.4 \times 10^{6}$ copies $^{-1}$ in the first $24 \mathrm{hr}$ and remains at this abundance for the remaining incubation. Interestingly, in the presence of ATU the abundance of bacterial amo $A$ cDNA is less than $5.0 \times 10^{2}$ copies $\mathrm{g}^{-1}$. Archaeal amoA cDNA abundance is also low.

Gene expression in the $4 \mathrm{~m}$ incubations is unlike the two shallower incubations. Bacterial 16S rRNA cDNA abundance is lower than found in the other incubations, ranging from $5.1 \times 10^{5}$ to $8.3 \times 10^{5}$ copies $\mathrm{g}^{-1}$ while archaeal $16 \mathrm{~S}$ rRNA cDNA abundance 
was comparable to other incubations, $6.7 \times 10^{6}$ to $9,1 \times 10^{6}$ copies $^{-1}$ (Figure 4). Unlike the shallow incubation both amoA cDNA abundance remain low during the incubation. Bacterial amo $A$ abundance varies from $5.4 \times 10^{2}$ to $8.4 \times 10^{2}$ copies $\mathrm{g}^{-1}$ while archaeal amo $A$ ranges from $5.6 \times 10^{2}$ to $8.9 \times 10^{2}$ copies $\mathrm{g}^{-1}$ under the same conditions. Gene express of all four genes was consistent between the ammonium and ammonium plus ATU incubations.

\section{Discussion}

The three groundwater parcels, based on salinity, of the Waquoit Bay aquifer have previously been described in detail (Charette et al. 2005; Kroeger and Charette 2008). Briefly they include: (1) a surface salt zone that is the result of mixing between meteoric waters and overtopping bay water from tidal and wind driven circulation, (2) a fresh groundwater and (3) a tidally driven deep salt wedge. These parcels represent three distinct geochemical environments within which nitrogen transformations can occur. Within these three zones previous studies have shown the presence of different microbial communities (Chapter 2) and potentially different biogeochemical processes in regard to nitrogen cycling (Chapter 3; (Kroeger and Charette 2008; Spiteri et al. 2008). This study aims to estimate the rate of nitrification within each parcel by following the transfer of ${ }^{15} \mathrm{~N}$ from the $\mathrm{NH}_{4}{ }^{+}$to $\mathrm{NO}_{3}{ }^{-}$pools. Furthermore, gene expression of relevant functional genes are quantified over the time course of the experiment with the goal of elucidating which groups of organisms may be active. 


\section{Surface Meter}

In earlier work, a large community of AOAs was observed in the surface meter (Chapter 2). Here we show through quantification of archaeal amoA transcripts that these AOA are active. Furthermore, the transfer of the ${ }^{15} \mathrm{~N}$ tracer from the ammonium to the nitrate pools confirms nitrification at this depth. ATU is believed to specifically inhibit ammonia oxidation by chelating the copper atom, obstructing the active site of the ammonia monooxygenase enzyme (Ginestet et al. 1998), however, in complex community and environment such as the sediments ATU may have unforeseen reactions. For example, ATU may be titrated by the presence of aqueous or sedimentary copper or perhaps by interactions with organisms and molecules other than those intended. These interactions are difficult to measure or predict in complex environmental settings.

The resulting nitrification rates $\left(456 \mathrm{pmol} \mathrm{g}^{-1}\right.$ sediment day $\left.{ }^{-1}\right)$ are comparable to those reported for estuarine sediments (400 to $9000 \mathrm{nmol} \mathrm{m}^{-2} \mathrm{day}^{-1}$ or $11 \mathrm{pmol} \mathrm{g}^{-1}$ sediment day ${ }^{-1}$ to $257 \mathrm{pmol} \mathrm{g}^{-1}$ sediment day $\left.{ }^{-1}\right)($ Henriksen et al. 1981; Caffrey et al. 2003). Compared to carbon rich environment like salt marsh sediment our nitrification rate estimates are 100 to 1000 times slower (Dollhopf et al. 2005). The activity observed in this zone is important because much of the groundwater discharge may transit through a brackish zone similar to this prior to discharge. However, given the short residence time of water in the upper meter (Michael et al. 2005), and the observed 1-5 $\mu \mathrm{M} \mathrm{NH}_{4}{ }^{+}$ concentrations (Chapter 3 ) it is possible that the biological rates are too slow to completely consume ammonium either transported in from the bay, remineralized from organic matter or release through cation exchange as saline water invades. Oxidation of 
ammonium in this zone would result in a lighter $\left(\operatorname{smaller} \delta^{15} \mathrm{~N}\right)$ nitrate pool, which is not the pattern that has been observed (Chapter 3). However, it is likely that the observed ratio of $\delta^{18} \mathrm{O} / \delta^{15} \mathrm{~N}$ (Chapter 3 ) is not solely a signal of denitrification in this or other groundwater environments (Böttcher et al. 1990). Likely, these environments harbor both nitrifying and denitrifying communities whose coupled metabolism produce the observed ratio of $\mathrm{N}$ and $\mathrm{O}$ isotopes in the nitrate pool.

\section{Fresh Groundwater Plume}

The fresh groundwater plume has been described as a location where AOBs may be more important than AOA due to the relative abundance of their respective amo $\mathrm{A}$ genes (Chapter 2). Our data here corroborates this hypothesis by showing both an abundance of active AOBs (through bacterial amoA transcripts) and transfer of the isotopic label from the reduced to oxidized nitrogen pools. The potential rates of nitrification at $2 \mathrm{~m}$ are equal to that of shallow aquifer sediments. Interestingly, the presence of ATU completely blocks nitrification at this depth, suggesting that nitrifier community at this depth is sensitive to the inhibitor. We interpret this sensitivity as an indication that the active nitrifier community is mainly bacterial as opposed to archaeal in the freshwater plume. Interestingly, a drop in the expression level of bacterial amoA genes also occurred in the presence of ATU. This is unexpected because ATU is a copper chelator, binding to and physically blocking the active site of the ammonia monooxygenase enzyme. If the enzyme is blocked it does not function and it would be expected that the expression levels of the gene encoding for the needed metabolic 
enzyme would remain elevated. However, ATU could have other effects in the complex environment represented by the bottle incubations. One possible explanation is that ATU altered a factor that promotes the expression of the functional gene. Another explanation could be that the ATU altered some other required enzyme system in the organisms at this depth that resulted in the population no longer metabolizing ammonia. A third possibility could be that ATU reacted with the sediment matrix at this depth, perhaps cleaving the inhibitor or otherwise altering the chemical environment that resulted in the organisms no longer processing the added ammonia. At this point, it is unclear why the addition of ATU resulted in the loss of the bacterial amoA gene expression signal. The archaeal amoA expression at this depth was low both in the presence and absence of the inhibitor indicating that archaea are probably not the major ammonia-oxidizers within the core of the freshwater nitrate plume.

The presence of an active population of $\mathrm{AOB}$ at this depth is interesting because ammonium is not observed here as it is in the surface and deep salt wedge. However, there are possible sources of ammonia in this zone such as in situ remineralization of organic matter or perhaps the advection of ammonium-bearing water into the fresh groundwater plume. The sands as this depth in the aquifer are carbon poor, thus ammonia generation ought to be small. Likewise, an advecting ammonia plume has not been observed at the current study site, though such a plume has been mapped about $0.5 \mathrm{~km}$ east. If an ammonium plume similar to the one in the east were to enter this zone it is unlikely, given the reaction rates and high concentrations of ammonia $(>50 \mu \mathrm{M})$, that the 
ammonia would be efficiently attenuated in this zone though this is dependent on the rate of advection.

\section{Deep Salt Wedge}

The deep salt wedge has been shown to harbor a large abundance of archaeal amo $A$ genes (Chapter 2). This has been interpreted as a population of AOA. Curiously, our examination has not demonstrated the presence of an active ammonia-oxidizing population. Gene expression for both $a m o A$ versions was low and there was not a transfer of label between the ammonium and nitrate pools. The ammonium from the deep salt wedge has been described as mixing nearly conservatively entering the freshwater plume from below with some evidence of ammonium loss (Kroeger and Charette 2008). The data presented above is not consistent with an AOA population ready to consume ammonium as soon as it is available. If this population was tuned to ammonium metabolism, the addition of the tracer ought to have stimulated consumption. Of course, our experimental procedure may not mimic the environment accurately enough to maintain a viable population of AOA from this depth. There are a few possible explanations for this inactivity in the deep AOA population, first perhaps these organisms are limited by some other required growth element that is not limiting in the surface sediments, perhaps this population is more sensitive to the handling required to set up cultures, especially changing oxygen concentrations or perhaps the lag time of this population is greater than the $96 \mathrm{hr}$ of the experiment. Alternatively, anammox processes, either biological or by oxidation with Mn-oxides could also account for the loss of 
ammonium at this depth (Kroeger and Charette 2008). Biological anammox processes may or may not be linked to archaeal nitrification as has been suggest for the Black Sea (Lam et al. 2007) and Peruvian upwelling (Lam et al. 2009). Future work and technique development will be able to elucidate this relationship.

\section{Conclusions}

This work confirms the presence of different communities of ammonia-oxidizers throughout the upper meters of the Waquoit Bay groundwater system. The upper meter of the aquifer harbors an active population of archaeal ammonia-oxidizers, which appear to be responsible for the production of oxidized nitrogen species at potential rates comparable to estuarine sediments. In contrast, bacteria appeared to be the active nitrifiers in the freshwater plume. Further work is needed to determine the geochemical role of the deep archaeal population, which did not appear active in nitrification at the time of our sampling. Prior evidence suggests that a fraction of these deep archaea possess the amo $A$ gene; however, the gene was not expressed under the incubation conditions in this study. In fact, no nitrification was evident within the deep salt wedge even when $\mathrm{NH}_{4}{ }^{+}$was added. Closer examination of this deep population of archaea, including cultivation could shed new light on the metabolism of these organisms. 


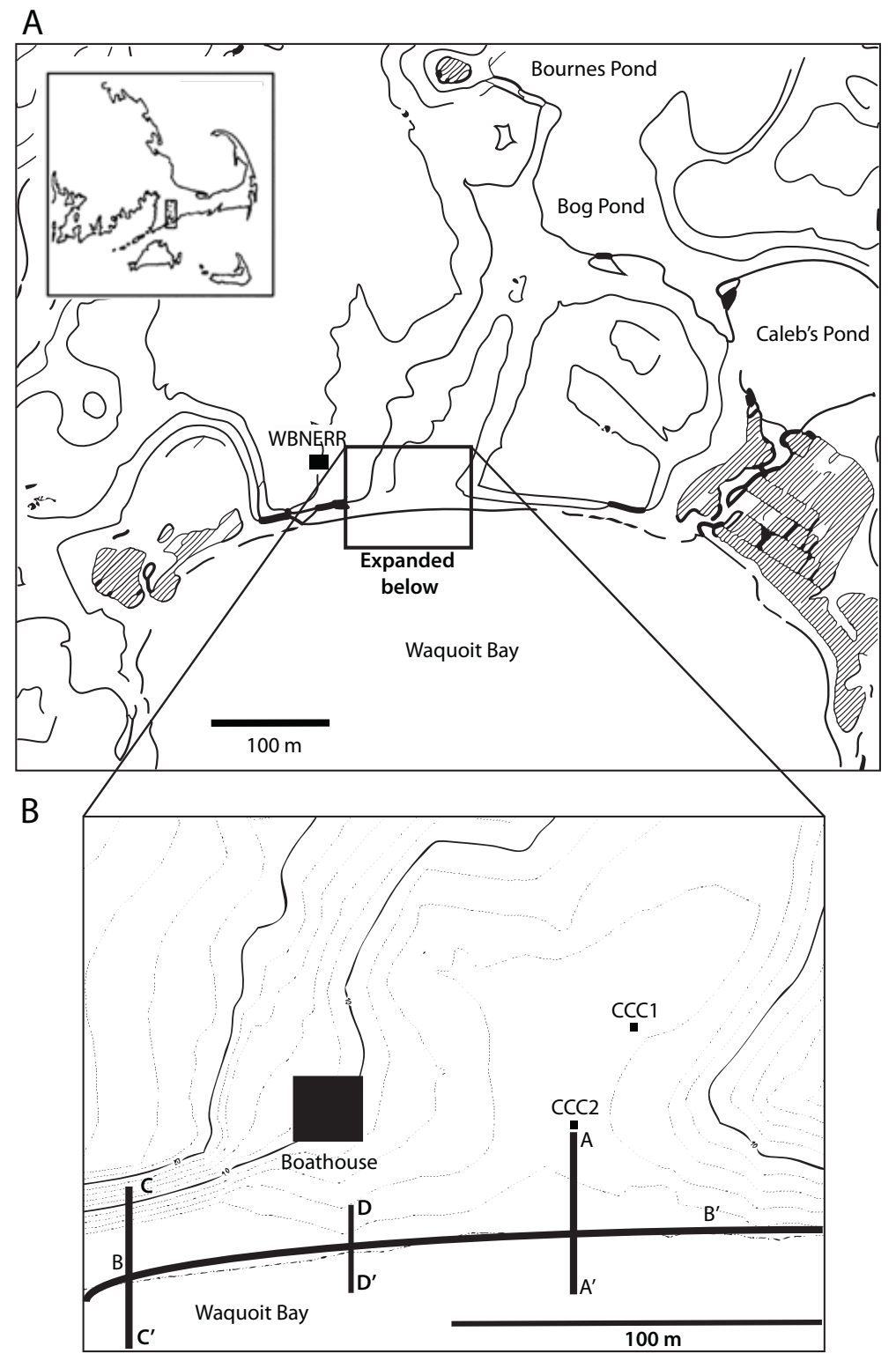

Figure 1. (A) Head of the bay, Waquoit Bay, Cape Cod, MA. Contours represent $10 \mathrm{ft}$. intervals and hatched area denotes wetlands. (B) The current and previous study locations are depicted, Cape Cod Commission wells (CCC1, CCC2), transect from Charette et al. 2005, 2006 (A to A') and Kroeger et al. (2008) (A to A', B to B' and C to C'). Mulligan and Charette (2006) extended the B to B' transect east and west. 

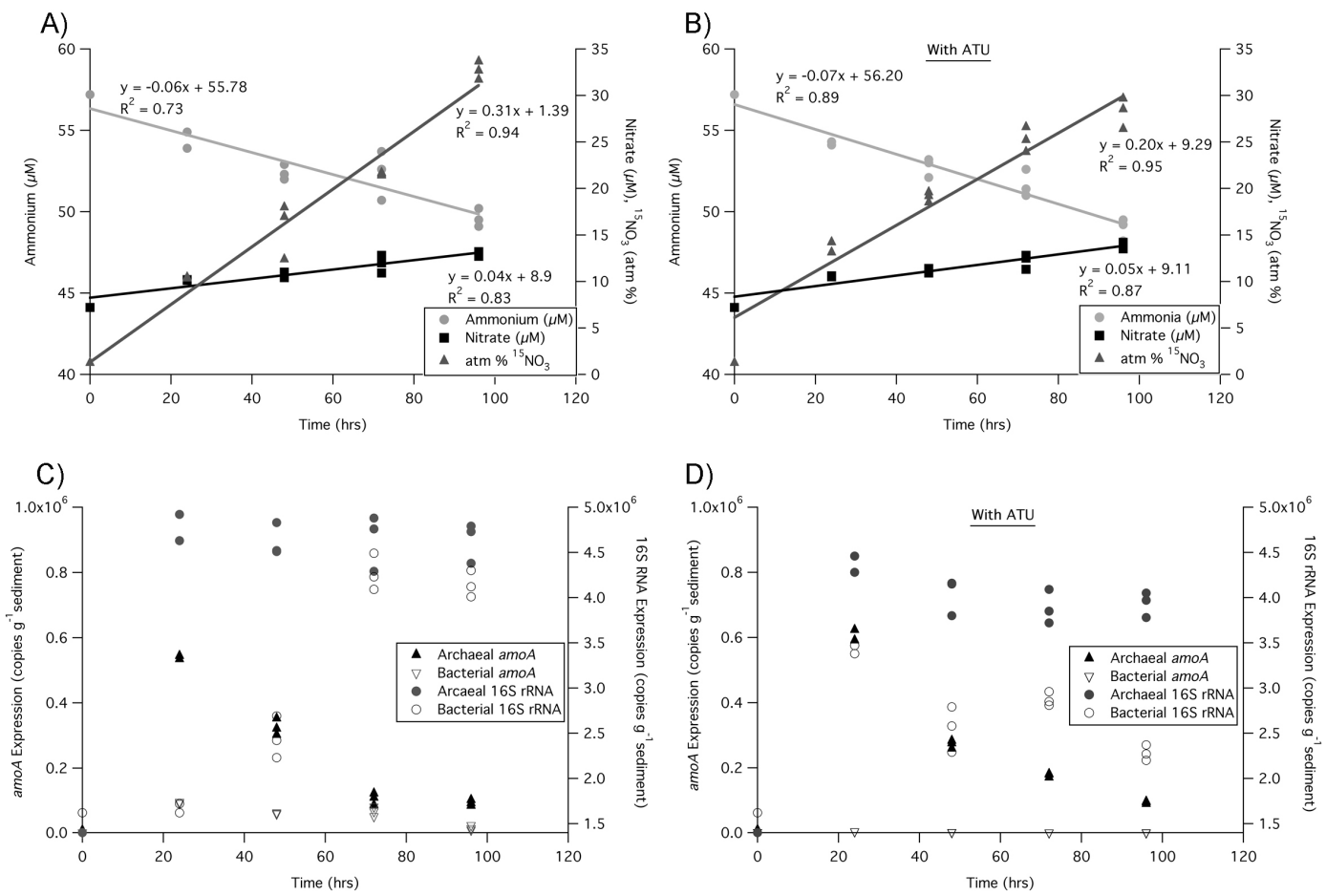

Figure 2. Shallow ( $0.6 \mathrm{~m})$ incubation time course. A) Ammonium ( $\mu \mathrm{M}$, circles), nitrate ( $\mu \mathrm{M}$, squares) and ${ }^{15} \mathrm{NO}_{3}$ atom \% (triangles) are plotted against time during an $50 \mu \mathrm{M}$, 99.5 atom $\%{ }^{15} \mathrm{NH}_{4}{ }^{+}$slurry incubation. Ammonium decreases while nitrate and ${ }^{15} \mathrm{NO}_{3}$ increase over the coarse of the experiment. B) Ammonium ( $\mu \mathrm{M}$, circles), nitrate $(\mu \mathrm{M}$, squares) and ${ }^{15} \mathrm{NO}_{3}$ atom \% (triangles) development in the ammonium plus ATU incubations. C) Gene expression (qRT-PCR) data for archaeal and bacterial amo $A$ and $16 \mathrm{~S}$ rRNA cDNA during the time course of the labeled ammonium incubation. D) Gene expression (qRT-PCR) data for archaeal and bacterial amo $A$ and 16S rRNA cDNA during the time course of the labeled ammonium plus ATU incubation. 

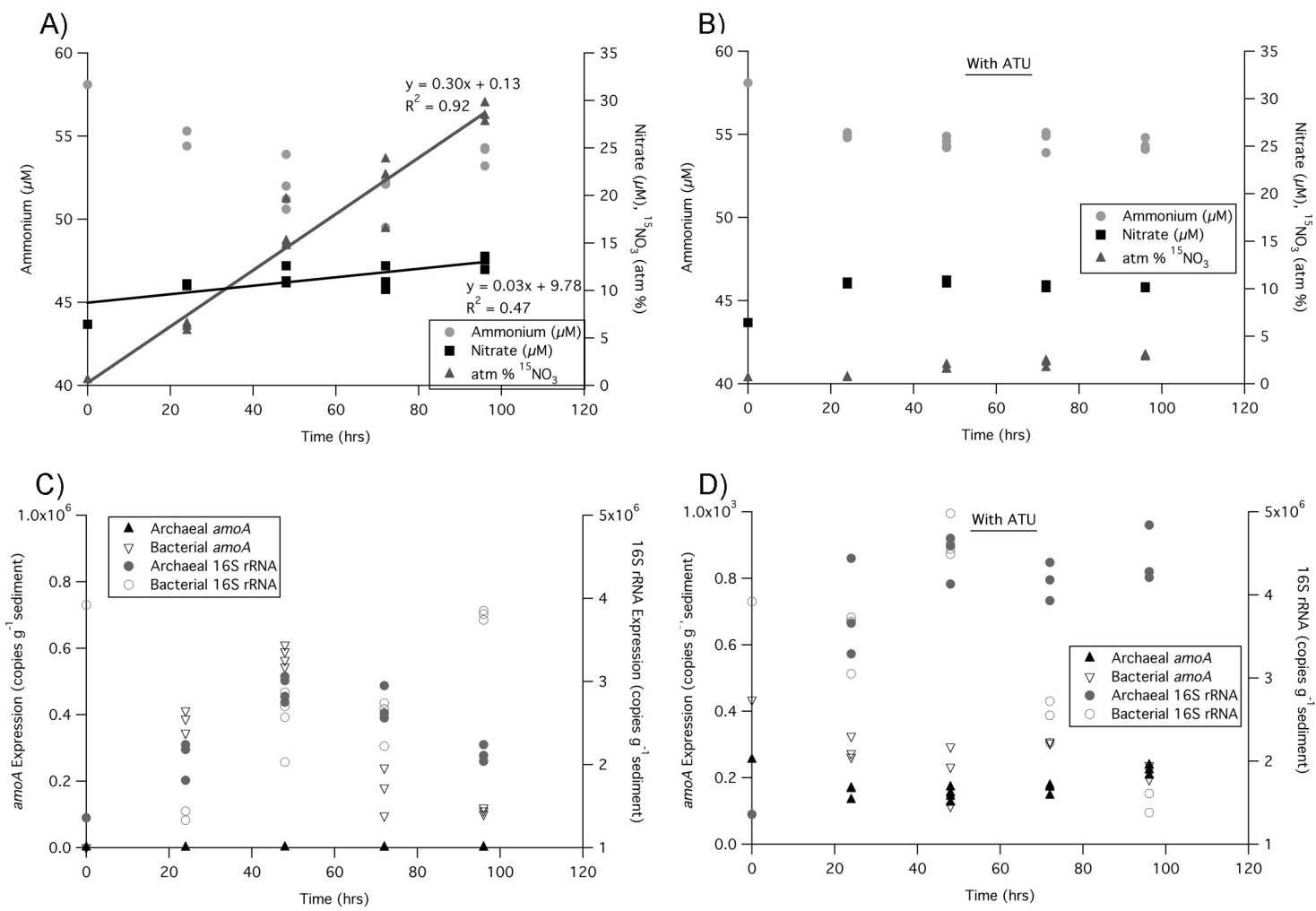

Figure 3. Tracer incubation using sediments and water collected from $2 \mathrm{~m}$. A) Ammonium ( $\mu \mathrm{M}$, circles), nitrate $\left(\mu \mathrm{M}\right.$, squares) and ${ }^{15} \mathrm{NO}_{3}$ atom $\%$ (triangles) are plotted against time during an $50 \mu \mathrm{M}, 99.5$ atom $\%{ }^{15} \mathrm{NH}_{4}{ }^{+}$slurry incubation. Ammonium decreases while nitrate and ${ }^{15} \mathrm{NO}_{3}$ increase over the coarse of the experiment. B) Ammonium ( $\mu \mathrm{M}$, circles), nitrate ( $\mu \mathrm{M}$, squares) and ${ }^{15} \mathrm{NO}_{3}$ atom \% (triangles) development in the ammonium plus ATU incubations. C) Gene expression (qRT-PCR) data for archaeal and bacterial amoA and 16S rRNA cDNA during the time course of the labeled ammonium incubation. D) Gene expression (qRT-PCR) data for archaeal and bacterial amoA and $16 \mathrm{~S}$ rRNA cDNA during the time course of the labeled ammonium plus ATU incubation. 

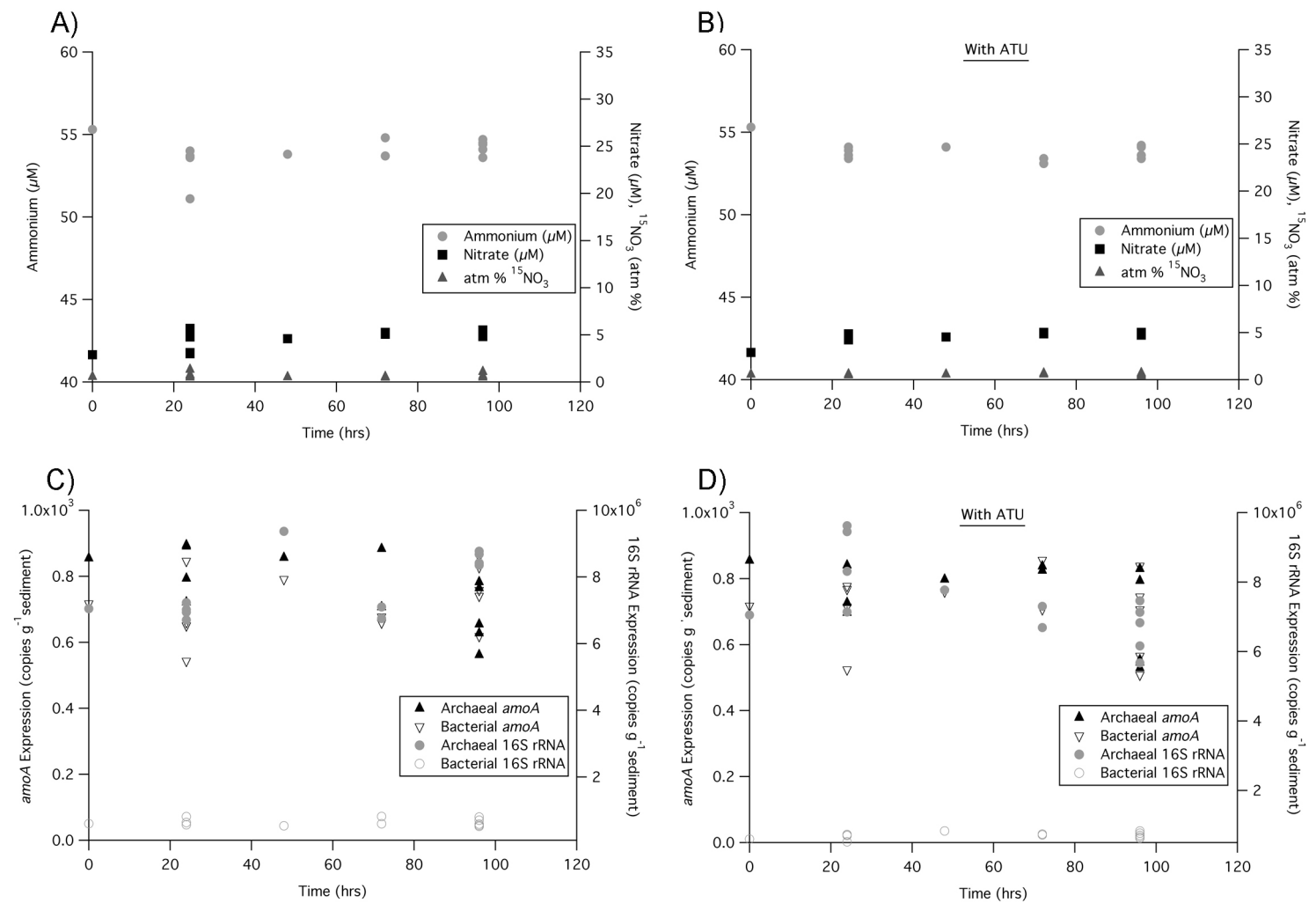

Figure 4. Tracer incubation using sediments and water collected from $4 \mathrm{~m}$. A) Ammonium ( $\mu \mathrm{M}$, circles), nitrate $\left(\mu \mathrm{M}\right.$, squares) and ${ }^{15} \mathrm{NO}_{3}$ atom $\%$ (triangles) are plotted against time during an $50 \mu \mathrm{M}, 99.5$ atom $\%{ }^{15} \mathrm{NH}_{4}{ }^{+}$slurry incubation. Ammonium decreases while nitrate and ${ }^{15} \mathrm{NO}_{3}$ increase over the coarse of the experiment. B) Ammonium ( $\mu \mathrm{M}$, circles), nitrate ( $\mu \mathrm{M}$, squares) and ${ }^{15} \mathrm{NO}_{3}$ atom \% (triangles) development in the ammonium plus ATU incubations. C) Gene expression (qRT-PCR) data for archaeal and bacterial amoA and 16S rRNA cDNA during the time course of the labeled ammonium incubation. D) Gene expression (qRT-PCR) data for archaeal and bacterial amoA and $16 \mathrm{~S}$ rRNA cDNA during the time course of the labeled ammonium plus ATU incubation. 
A)

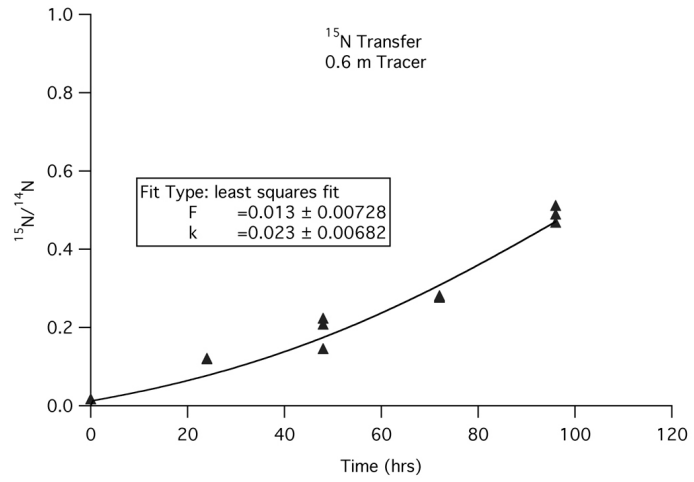

C)

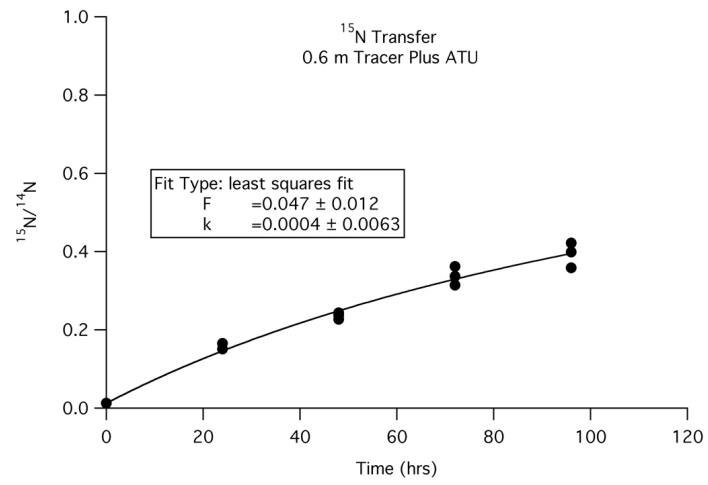

B)

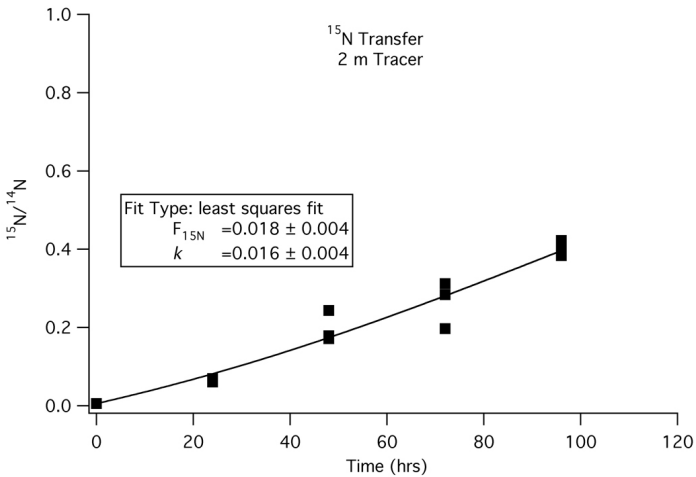

D)

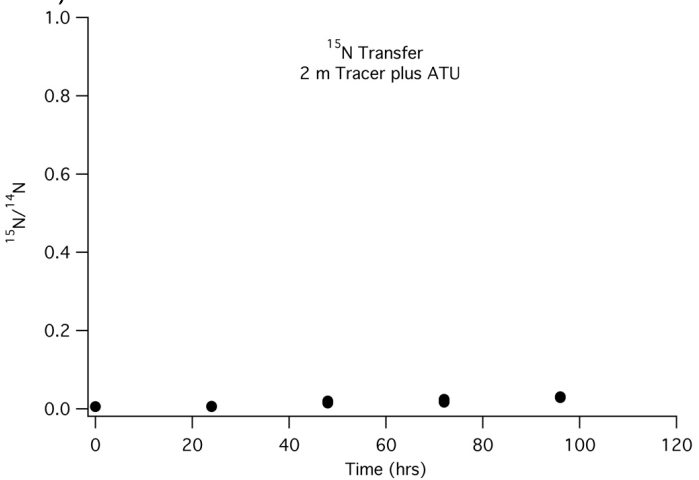

Figure 5. Nitrification rates as calculated by $15 \mathrm{~N}$-label transfer from ammonium to nitrate pools. A simple box model was fit to the ratio of $15 \mathrm{~N} / 14 \mathrm{~N}$ over time using Igor Pro. A) $0.6 \mathrm{~m}$ incubations, B) $2 \mathrm{~m}$ incubations, C) $0.6 \mathrm{~m}$ plus ATU incubations and D) 2 $\mathrm{m}$ plus ATU incubations. 


\section{References}

Böttcher, J., O. Strebel, S. Voerkelius and H. Schmidt (1990). "Using isotope fractionation of nitrate-nitrogen and nitrate-oxygen for evaluation of microbial denitrification in a sandy aquifer." Journal of Hydrology 114: 413-424.

Burnett, W. C., H. Bokuniewicz, M. Huettel, W. S. Moore and M. Taniguchi (2003). "Groundwater and pore water inputs to the coastal zone." Biogeochemistry 66(1 2): 3.

Bustin, S. (2000). "Absolute quantification of mRNA using real-time reverse transcription polymerase chain reaction assays." Journal of molecular endocrinology 25(2): 169.

Caffrey, J., N. Harrington, I. Solem and B. Ward (2003). "Biogeochemical processes in a small California estuary. 2. Nitrification activity, community structure and role in nitrogen budgets." Marine Ecology Progress Series 248: 27-40.

Caffrey, J. M., N. Bano, K. Kalanetra and J. T. Hollibaugh (2007). "Ammonia oxidation and ammonia-oxidizing bacteria and archaea from estuaries with differing histories of hypoxia." ISME Journal 1(7): 660-662.

Charette, M. and E. Sholkovitz (2002). "Oxidative precipitation of groundwater-derived ferrous iron in the subterranean estuary of a coastal bay." Geophysical Research Letters 29(10): 1444.

Charette, M. A., E. R. Sholkovitz and C. M. Hansel (2005). "Trace element cycling in a subterranean estuary: Part 1. Geochemistry of the permeable sediments." Geochimica et Cosmochimica Acta 69(8): 2095.

Cohen, J. E., C. Small, A. Mellinger, J. Gallup, Sachs, J. , P. M. Vitousek, Mooney and H. A. (1997). "Estimates of Coastal Populations." Science 278(5341): 1209c1213.

de la Torre, J. R., C. B. Walker, A. E. Ingalls, M. Konneke and D. A. Stahl (2008). "Cultivation of a thermophilic ammonia oxidizing archaeon synthesizing crenarchaeol." Environmental Microbiology 10(3): 810-818.

Edwards, K. J., P. L. Bond and J. F. Banfield (2000). "Characteristics of attachment and growth of Thiobacillus caldus on sulfide minerals: A chemotactic response to sulfur minerals." Environmental Microbiology 2: 324-332.

Francis, C. A., G. D. Mullan and B. B. Ward (2003). "Diversity of ammonia monooxygenase (amoA) genes across environmental gradients in Chesapeake Bay sediments." Geobiology 1(2): 129-140.

Francis, C. A., K. J. Roberts, J. M. Beman, A. E. Santoro and B. B. Oakley (2005). "Ubiquity and diversity of ammonia-oxidizing archaea in water columns and sediments of the ocean." PNAS 102(41): 14683-14688.

Ginestet, P., J. Audic, V. Urbain and J. Block (1998). "Estimation of nitrifying bacterial activities by measuring oxygen uptake in the presence of the metabolic inhibitors allylthiourea and azide." Applied and Environmental Microbiology 64(6): 2266.

Hallam, S. J., T. J. Mincer, C. Schleper, C. M. Preston, K. Roberts, P. M. Richardson and E. F. DeLong (2006). "Pathways of carbon assimilation and ammonia oxidation 
suggested by environmental genomic analyses of marine crenarchaeota." PLoS Biology 4(4): e95.

Henriksen, K., J. Hansen and T. Blackburn (1981). "Rates of nitrification, distribution of nitrifying bacteria, and nitrate fluxes in different types of sediment from Danish waters." Marine Biology 61(4): 299-304.

Holmes, R., J. McClelland, D. Sigman, B. Fry and B. Peterson (1998). "Measuring 15N$\mathrm{NH} 4+$ in marine, estuarine and fresh waters: An adaptation of the ammonia diffusion methof for samples with low ammonium concentrations." Marine Chemistry 60: 235-243.

Hooper, A. and K. Terry (1973). "Specific inhibitors of ammonia oxidation in Nitrosomonas." Journal of Bacteriology 115(2): 480.

Howarth, R. W., A. Sharpley and D. Walker (2002). "Sources of nutrient pollution to coastal waters in the United States: Implicatoins for achieving coastal water quality goals." Estuaries 45(4b): 656-676.

Konneke, M., A. E. Bernhard, J. R. de la Torre, C. B. Walker, J. B. Waterbury and D. A. Stahl (2005). "Isolation of an autotrophic ammonia-oxidizing marine archaeon." Nature 437(7058): 543.

Kroeger, K. D. and M. A. Charette (2008). "Submarine groundwater discharge: nitrogen biogeochemistry of the discharge zone." Limnol. Oceanogr 53(3): 1025-1039.

Lam, P., M. M. Jensen, G. Lavik, D. F. McGinnis, B. Muller, C. J. Schubert, R. Amann, B. Thamdrup and M. M. M. Kuypers (2007). "Linking crenarchaeal and bacterial nitrification to anammox in the Black Sea." PNAS: 0611081104.

Lam, P., G. Lavik, M. M. Jensen, J. van de Vossenberg, M. Schmid, D. Woebken, D. Gutierrez, R. Amann, M. Jetten and M. M. M. Kuypers (2009). "Revising the nitrogen cycle in the Peruvian oxygen minimum zone." Proc Natl Acad Sci USA 106: 4752-4757.

Leininger, S., T. Urich, M. Schloter, L. Schwark, J. Qi, G. W. Nicol, J. I. Prosser, S. C. Schuster and C. Schleper (2006). "Archaea predominate among ammoniaoxidizing prokaryotes in soils." Nature 442(7104): 806.

Martens-Habbena, W., P. M. Berube, H. Urakawa, J. R. de la Torre and D. A. Stahl (2009). "Ammonia oxidation kinetics determine niche separation of nitrifying Archaea and Bacteria." Nature 461(7266): 976-979.

Michael, H. A., A. E. Mulligan and C. F. Harvey (2005). "Seasonal oscillations in water exchange between aquifers and the coastal ocean." Nature 436(7054): 1145-1148.

Moore, W. S. (1999). "The subterranean estuary: A reaction zone of ground water and sea water." Marine Chemistry 65: 111-125.

O'Mullan, G. D. and B. B. Ward (2005). "Relationship of Temporal and Spatial Variabilities of Ammonia-Oxidizing Bacteria to Nitrification Rates in Monterey Bay, California." Appl. Environ. Microbiol. 71(2): 697-705.

Santoro, A. E., C. A. Francis, N. R. de Sieyes and A. B. Boehm (2008). "Shifts in the relative abundance of ammonia-oxidizing bacteria and archaea across physicochemical gradients in a subterranean estuary." Environmental Microbiology 10(4): 1068-1079. 
Sigman, D., M. Altabet, D. McCorkle, R. Francois and G. Fischer (1999). "The 15N of nitrate in the Southern Ocean: consumption of nitrate in surface waters." Global Biogeochemical Cycles 13(4).

Sigman, D. M., M. A. Altabet, R. Michener, D. C. McCorkle, B. Fry and R. M. Holmes (1997). "Natural abundance-level measurement of the nitrogen isotopic composition of oceanic nitrate: an adaptation of the ammonia diffusion method." Marine Chemistry 57(3-4): 227-242.

Sigman, D. M., K. L. Casciotti, M. Andreani, C. Barford, M. Galanter and J. K. Bohlke (2001). "A Bacterial Method for the Nitrogen Isotopic Analysis of Nitrate in Seawater and Freshwater." Anal. Chem. 73(17): 4145-4153.

Spiteri, C., C. Slomp, M. Charette, K. Tuncay and C. Meile (2008). "Flow and nutrient dynamics in a subterranean estuary (Waquoit Bay, MA, USA): field data and reactive transport modeling." Geochimica et Cosmochimica Acta 72(14): 33983412.

Treusch, A. H., S. Leininger, A. Kletzin, S. C. Schuster, H.-P. Klenk and C. Schleper (2005). "Novel genes for nitrite reductase and Amo-related proteins indicate a role of uncultivated mesophilic crenarchaeota in nitrogen cycling." Environmental Microbiology 7: 1985.

Valiela, I., J. Costa, K. Foreman, J. Teal, B. Howes and D. Aubrey (1990). "Transport of groundwater-borne nutrients from watersheds and their effects on coastal waters." Biogeochemistry 10: 177-197.

Valiela, I., K. Foreman, M. LaMontagne, D. Hersh, J. Costa, P. Peckol, B. DeMeoAndreson, C. D'Avanzo, M. Babione, C.-H. Sham, J. Brawley and K. Lajtha (1992). "Couplings of watersheds and coastal waters: Sources and consequences of nutrient enrichment in Waquoit Bay, Massachusetts." Estuaries 15(4): 443-457.

Venter, J. C., K. Remington, J. F. Heidelberg, A. L. Halpern, D. Rusch, J. A. Eisen, D. Wu, I. Paulsen, K. E. Nelson, W. Nelson, D. E. Fouts, S. Levy, A. H. Knap, M. W. Lomas, K. Nealson, O. White, J. Peterson, J. Hoffman, R. Parsons, H. BadenTillson, C. Pfannkoch, Y.-H. Rogers and H. O. Smith (2004). "Environmental genome shotgun sequencing of the Sargasso Sea." Science 304(5667): 66-74.

Ward, B. (2005). "Temporal variability in nitrification rates and related biogeochemical factors in Monterey Bay, California, USA." Marine Ecology Progress Series 292: 97-109.

Ward, B. B. (1987). "Nitrogen transformations in the Southern California Bight." Deep Sea Research 34: 785-805.

Winogradsky, S. (1890). "Recherches sur les organismes de la nitrification." Ann. Inst. Pasteur 4(257): 11-12.

Wuchter, C., B. Abbas, M. J. L. Coolen, L. Herfort, J. van Bleijswijk, P. Timmers, M. Strous, E. Teira, G. J. Herndl, J. J. Middelburg, S. Schouten and J. S. Sinninghe Damste (2006). "Archaeal nitrification in the ocean." PNAS 103(33): 1231712322. 
Chapter 5: Waquoit Bay: Looking back through the sands and looking forward.

Daniel Rogers and Karen Casciotti

Department of Marine Chemistry and Geochemistry and ${ }^{\star}$ MIT/WHOI Joint Program in Chemical Oceanography, Woods Hole Oceanographic Institution, Woods Hole MA 02543.

\footnotetext{
${ }^{*}$ Corresponding author

phone: 508-289-3748

fax: 508-457- 2076

email: drogers@whoi.edu
} 


\section{Introduction}

Throughout coastal Massachusetts and on Cape Cod in particular, groundwater

quality is heavily impacted by population density (as measured by individuals or housing per acre) with the principle impact on nitrogen loading (Persky 1986; Valiela et al. 1992; Sham et al. 1995; McClelland et al. 1997; McClelland and Valiela 1998; Cole et al. 2006). This nitrogen, initially in reduced forms, is transformed primarily to nitrate and enters coastal waters as new nitrogen through surface waters and groundwater discharge. Interest in groundwater as a freshwater input to coastal waters has increased in recent years due to of the projected magnitude of the water flux, chemical constituents associated with this flux, and potential impact of those constituents compared to overland runoff (rivers and storm water).

The subterranean estuary at Waquoit Bay is an appropriate and tractable model system in which to study microbe-mediated transformations of anthropogenic nitrogen for several reasons related to both the physical and chemical environment. First, the presence of a sandy aquifer is common, especially in the areas where glaciation has altered the underlying strata. Second, the large population burden on natural resources and anthropogenic influence on the aquifer system is common. This setting should serve as an analog to many temperate coastal watersheds including places such as Long Island, NY. In addition, there is a good deal of relevant previous and ongoing research conducted at this site to provide context, although very little microbiology has been done in this system. 
Our work has shown the presence of the archaeal ammonia monooxygenase gene $(a m o A)$ at all sampling depths while the bacterial version of the gene is only abundant in the core of the freshwater plume (Chapter 2). Interestingly, our data show that archaeal amo $A$ expression and the resulting nitrification dominate in the surface meter while the bacterial counterparts are more abundant in the core of the freshwater plume (Chapter 4).

Denitrification within the groundwater system has also been demonstrated using chemical and gene abundance data (Chapter 3). The isotopic ratios of the nitrate pool, $\delta^{15} \mathrm{~N}_{\mathrm{NO} 3}$ and $\delta^{18} \mathrm{O}_{\mathrm{NO} 3}$, increase while the nitrate concentration decreases moving from $1 \mathrm{~m}$ toward the surface. Over the same interval denitrification genes have been detected, with the gene encoding for the copper-based nitrite reductase enzyme dominant at this depth (Chapter 3). Interestingly, tracer experiments coupled with gene expression data demonstrate active nitrification may also occur over the same depth range as denitrification (Chapter 4).

Ladderane lipids, a biomarker for anammox organisms, and crenarchaeol, a biomarker associated with crenarchaeota, have also been detected within the aquifer with peaks in both lipids associated with the mixing zones between the freshwater plume and the two saline waters (Saenz, personal communication). Thus, this subterranean estuary has biological markers indicating that a variety of nitrogen transformation pathways within the system, many of which may be overlapping in depth or co-occurring. The discussion that follows is an effort to place our geomicrobiological data and interpretations in the context of previous geochemical and modeling work at Waquoit Bay. 


\section{The Bay Proper}

Waquoit Bay is a semi-enclosed estuary located on the Southwest coast of Cape Cod, in the town of Falmouth, MA. The bay is contained by the landmasses of Cape Cod to the north and Washburn Island to the south. The bay has direct communication with Vineyard Sound to the south through a small (ca $200 \mathrm{~m}$ ) straight bay between Washburn Island and South Cape Beach State Park (Cape Cod, MA) to the east. Indirect communication with Vineyard Sound also occurs through a small but navigable waterway in the northwestern part of the bay, traveling along the western edge of Washburn Island through the narrow Eel Pond.

The geologic setting of the western end of Cape Cod, and thus Waquoit Bay, consists of sand and silt deposited on a gravel bed during the retreat of the Wisconsin glaciation (Oldale 1976; Oldale and O'Hara 1984). These highly permeable soils allow

for high groundwater recharge from precipitation (ca. $\left.114 \mathrm{~cm} \mathrm{y}^{-1}\right)$ (Walter et al. 2004) leading to groundwater fed streams and rivers with little overland runoff (Cambareri and Eichner 1998). Water table height in the surrounding area shows some seasonality with peak water table heights in April, following a net recharge from late autumn to early spring, and water table lows occurring in December, following net evapotranspiration from late spring to early autumn (Michael et al. 2005). Direct groundwater discharge is estimated to account for $34 \%$ of the freshwater flux into Waquoit Bay, while atmospheric deposition is responsible for $11 \%$ of the freshwater (Cambareri and Eichner 1998). The majority of freshwater supply to Waquoit Bay comes by way of two rivers, the Quashnet 
and Child's rivers, which account for up to $55 \%$ of the freshwater flux (Cambareri and Eichner 1998). Precipitation- and radium-derived recharge estimates for total groundwater flux in to Waquoit bay range from 23,700 to 37,000 $\mathrm{m}^{3} \mathrm{~d}^{-1}$ (Cambareri and Eichner 1998; Charette et al. 2001). This flux includes both a freshwater flux ranging from $0.14-3.93 \mathrm{~m}^{3}$ day $^{-1} \mathrm{~m}^{-1}$ shore line and a recirculated seawater flux of $0.56-6.88 \mathrm{~m}^{3}$ day $^{-1} \mathrm{~m}^{-1}$ shore line, calculated by Darcy's law or specific seepage measurements (Cambareri and Eichner 1998; Michael et al. 2003; Michael et al. 2005; Mulligan and Charette 2006). The residence time of water in Waquoit Bay is 9.4 days, as determined by radium measurements (Charette et al. 2001). The tidal range within the bay is $1.1 \mathrm{~m}$. Waquoit Bay is a shallow with an average depth of $1 \mathrm{~m}$ over it $3 \mathrm{~km}^{2}$ area (Michael et al. 2003) draining a watershed of approximately $65 \mathrm{~km}^{2}$ (Charette et al. 2001).

The watershed is densely populated with 190 people $\mathrm{km}^{-2}$ (Kroeger et al. 2006; Spiteri et al. 2008), and therefore a significant nutrient input derived from private septic systems within the residential area (Valiela et al. 1992). Nutrient input in the bay has caused a decrease in the coverage area of sea grass as well as harming the population density of shellfish within the bay (Valiela et al. 1990; Bowen and Valiela 2001; Evgenidou and Valiela 2002). The majority of this nutrient input into the bay is due to wastewater $\left(10,998 \mathrm{~kg} \mathrm{yr}^{-1}, 48 \%\right)$ followed by atmospheric deposition (6923 $\mathrm{kg} \mathrm{yr}^{-1}$, $30 \%)$ and fertilizer (3442 $\left.\mathrm{kg} \mathrm{yr}^{-1}, 15 \%\right)$ (Valiela et al. 1997). 


\section{Groundwater Hydrology}

On a broad scale, groundwater input into Waquoit Bay supplies a significant amount of water and dissolved constituents to the shallow bay. Interestingly, from the current study and recent studies at different locations within the bay, the composition and flux of the groundwater constituents varies across the bay (Figure 1). Much of the previous work has focused on an area in the northern section of the bay where the Cape Cod Commission has installed wells for groundwater sampling (CCC line) and subsequent transect surveys have extended this line through the intertidal zone. These wells are placed in a topographic low, bound to the east and west by $6 \mathrm{~m}$ tall ridges and to the north by Bog pond and Bourne pond. The coring and transect sites of the current study are approximately $50 \mathrm{~m}$ west of the $\mathrm{CCC}$ line but within the bounds of previous work and mapping projects in the head of the bay. In general, the groundwater system at Waquoit Bay is composed of three main parcels of water (Figure 2), 1) the surface salt zone (also referred to as a brackish zone), 2) the freshwater plume and 3) the deep salt wedge. The major difference between the current study site (west of the CCC line) and previous work done at the $\mathrm{CCC}$ line and east, lies in the in the composition of the freshwater plume and the absence of an additional, reduced freshwater plume at our site. The freshwater plume at the current site, west of the CCC line, has similar oxygen concentrations compared to previous studies (average $86 \mu \mathrm{M} \mathrm{O}_{2}$ at core B vs. $78 \mu \mathrm{M}$, Kroeger and Charette 2008), however, ammonium is largely absent. West of the CCC line, ammonium is only observed in the surface salt zone $(<5 \mu \mathrm{M})$ and in the deep salt wedge (up to $53 \mu \mathrm{M}$ ). Ammonium is not observed within the freshwater parcel along the 
transect but could exist more landward. The source of this ammonium in the two salt zones is likely the aquifer sands due to ion exchange caused by the intruding saltwater (Charette and Sholkovitz 2006) or possibly the remineralization of organic matter, though organic carbon concentrations are low within the freshwater zone (Bone et al. 2007). At the CCC line and east, a reducing zone within the freshwater plume is consistently observed within the larger freshwater plume. At the CCC line this reducing zone contains large concentrations of ammonium $(>50 \mu \mathrm{M})$ (Charette et al. 2005; Kroeger and Charette 2008), manganese (up to $15 \mu \mathrm{M}$ ) (Charette et al. 2005) and ferrous iron (up to $175 \mu \mathrm{M}$ ) (Charette et al. 2005). In areas where this plume occurs, sediment coring reveals a zone of iron-oxide coated aquifer sands (Charette and Sholkovitz 2002). However, previous studies have reported that nitrate is the major dissolved nitrogen species entering Cape Cod coastal waters with ammonium accounting for only a small percentage (Valiela et al. 2000; Kroeger et al. 2006). The microbiology and geochemistry of three major parcels of water in the Waquoit Bay groundwater aquifer will be discussed below.

\section{Surface Salt Zone}

The surface salt zone originates from tidal or wave induced overtopping of bay water on to the surface sediments and mixing with the advecting freshwater plume. This water is recharged at high tide through clean coarse quartz sands and has a short residence time on the order of hours or days (Michael et al. 2005). Furthermore, tracer injections have shown that this saline water never reaches deeper than $1.2 \mathrm{~m}$ into the sediment column (Michael et al. 2005). The shallow salt zone contains nitrate mixed in 
from the freshwater plume, oxygen, and on occasion ammonium resulting from saltwater intrusion. Atmospheric deposition has been implicated as the source of the shallow nitrate east of our study site (Kroeger and Charette 2008), however, the $\delta^{15} \mathrm{~N}$ and $\delta^{18} \mathrm{O}$ of the nitrate pool at our study site is not consistent with an atmospheric source. Alternatively, the shallow nitrate could be the result of mixing the freshwater plume up into the overtopping seawater. Plotting nitrate against salinity for the upper meter is consistent with mixing, however, such mixing does not explain the enrichment in both $\mathrm{N}$ and $\mathrm{O}$ isotopes over this range. This parcel of water was only observed in the two most shoreward piezometer locations (locations A and B, Figure 2) in our study area.

Nitrogen biogeochemistry in this zone is complex. The ammonium pool is small in this setting and is only detectable in a few samples in the most shoreward site and even then only in the upper half meter with a maximum of $5 \mu \mathrm{M}$. The concentration of nitrate in the two most shoreward piezometer sites shows a decrease in concentration (ca. 40 to $12 \mu \mathrm{M})$ moving from $1 \mathrm{~m}$ up to the surface. With this decrease in nitrate concentration, the $\delta^{15} \mathrm{~N}_{\mathrm{NO} 3}$ and $\delta^{18} \mathrm{O}_{\mathrm{NO} 3}$ increase (4 to $20 \%$ and 2 to $10 \%$ respectively) from $1 \mathrm{~m}$ to the surface. This concurrent decrease in concentration and increase in both isotope values is consistent with a fractionating consumption process. The ratio $\left(0.56, \mathrm{r}^{2}=0.83\right)$ of $\delta^{18} \mathrm{O}_{\mathrm{NO} 3}$ and $\delta^{15} \mathrm{~N}_{\mathrm{NO} 3}$ during this fractionating process is consistent with previous studies of groundwater and sandy aquifer denitrification . Molecular queries show a microbial community similar to those found in marine and estuarine sediments. The recovered $16 \mathrm{~S}$ rRNA gene sequences include representatives that are most closely related to Stappiaand Mesorhizobium-like organisms. These genera encompass a large variety of metabolic 
lifestyles, including known denitrifying organisms though it is tenuous to assign ecological function based on 16S rRNA phylogeny. However, nitrite reductase (nirK and nirS) gene sequences were also recovered throughout the sediment core. In the upper meter of sediment the copper-based nirK gene was dominant over the cytochrome-based nirS gene.

Despite this in situ chemical and molecular evidence that denitrification may be important in the upper meter of the aquifer, incubation studies with labeled nitrate did not result in a production of labeled dinitrogen (not shown). These incubations were done approximating in situ chemistry at the time of sampling, including oxygen concentrations. Elevated oxygen concentrations $(50-100 \mu \mathrm{M})$, such as those reported during the chemical mapping in Chapter 3, have been shown to limit denitrification in the environment. These high oxygen concentrations may explain the observation that while denitrifiers may be present and though there is evidence of their activity in the environment, denitrification was not measureable in our bottle incubation over the time span of the experiments. On the other hand, we did find substantial evidence of active nitrification in the surface meter.

Incubation with labeled ammonium resulted in the transfer of the label to the nitrate pool. This transfer of nitrogen from the reduced to oxidized pool is mirrored by the up-regulation of ammonia monooxygenase subunit A ( $\mathrm{amoA})$. Incubations with labeled ammonium and the specific inhibitor allylthiourea (ATU) had little effect on the rate of isotope transfer in these incubations or the expression levels of the archaeal amo $\mathrm{A}$ gene. The presence of an active (defined by gene expression and transfer of nitrogen) 
archaeal nitrifying community is consistent with the quantitative study of the archaeal population, which demonstrated a peak in archaeal amoA genes in the upper half-meter of sediments (Chapter 2). Recovered amoA genes from this depth are most closely related to sequences obtained from water column and low salinity estuarine environments including Monterey Bay and northern San Francisco Bay.

Taken together, this zone appears to have both denitrifying and nitrifying capacity. Given the short residence time of the water in this area, and the development of fractionation in the natural abundance isotopes, denitrification ought happen at significant rates to maintain the isotope signal. Alternatively, an enriched source nitrate mixing with the groundwater could produce the same observed patterns. The surface bay water cannot be the source of this enriched nitrate as that pool has a low isotopic signature for both atoms $\left(\delta^{15} \mathrm{~N}=6 \%, \delta^{18} \mathrm{O}=3 \%\right)$. Furthermore, presence of an enriched nitrate source is less likely than our inability to maintain the denitrifier community in bottles. Perhaps microenvironments, such as grain surfaces or grain boundaries, where oxygen concentrations are limited by the balance of consumption processes like aerobic heterotrophy and diffusion from the surrounding waters are important in the biogeochemical cycling of nitrogen in the aquifer. The slurry approach used in the isotope tracer $\left({ }^{15} \mathrm{NH}_{4}{ }^{+}\right.$addition, Chapter 4) would necessarily eliminate such zones. In fact, the slurry incubations were shaken so that the diffusion of reactants would not limit metabolism. Of course in the case of an inhibiting substance such as oxygen to denitrifiers, agitation prevents the development of a protected harbor for the organisms. Nitrification is not limited in the same way by this experimental design. However, it is 
important to note that nitrification in these surface sediments is not affected by the addition of the traditional bacterial nitrification inhibitor ATU. Taken with the dominance of the archaeal amo $A$ gene, the data is interpreted as the upper meter of the aquifer harbors an active population of archaeal nitrifying organisms that are not inhibited by the presence of substrate level ATU.

\section{Freshwater Plume}

The freshwater plume is characterized by high concentrations of nitrate and oxygen, and to the east of the $\mathrm{CCC}$ line high concentrations of ammonium in a reducing plume. At the current study site the concentration contours of nitrate and oxygen in the freshwater plume are consistent throughout the transect, only shoaling as the transect progresses seaward and the deep salt wedge shoals. Contrary to enriched $\delta^{15} \mathrm{~N}_{\mathrm{NO}}$ reported near the CCC line (Nielsen et al. 1990), both $\delta^{15} \mathrm{~N}_{\mathrm{NO} 3}$ and $\delta^{18} \mathrm{O}_{\mathrm{NO} 3}$ remain steady throughout the transect (Chapter 3). Addition of label to the nitrate or ammonium in the isotope pairing experiments does not result in a production of labeled dinitrogen. At this depth the denitrification genes, nirK and nirS, show similar levels of abundance. Similar to the surface sediments a transfer of the label from the ammonium pool to the nitrate pool is observed at mid-depth, with potential rates similar to those of the surface meter. Interestingly, the addition of ATU to the incubation at $2 \mathrm{~m}$ prevented the transfer of label between the reduced and oxidized pools. The sensitivity of nitrification to ATU is consistent with a bacterially mediated process. This is congruent with the observation that the nitrate peak in the freshwater plume is the only zone where the bacterial version of 
the amo $A$ gene is dominant over the archaeal version. Examining the expression data is consistent with an active bacterial nitrifying population with little contribution from their archaeal counterparts as seen by the decline in both rate of ${ }^{15} \mathrm{~N}$ transfer and bacterial amoA expression in the presence of ATU.

\section{Deep Salt wedge}

The deep salt wedge is characterized by a sharp transition in salinity from freshwater to near bay water salinity in a half-meter. This study and previous studies have had difficulty obtaining samples with enough nitrate for natural abundance isotopic measurement of the nitrate pool due to the rapid loss of nitrate between the nitrate rich freshwater and nitrate lacking salt wedge. Molecular evidence suggests a peak in archaeal amo $A$ genes in the bottom of the nitrate plume $(2.8 \mathrm{~m})$ and an increase in nirS genes going into the deep salt wedge. Also of interest is the phylogenetic relationship between this deep archaeal amoA population and the shallow population. While the shallow population is closely related to water column type sequences, genes recovered from the deeper in the aquifer are more closely related to sediment and soil sequences. Like the shallower depths the paired isotope experiments did not show a transfer of tracer to the dinitrogen pool. Unlike the shallower sediments, however, the labeled ammonium experiments did not show a transfer of label in the nitrate pool. In addition, the gene expression data does not show significant transcript activity, compared to the shallow depths. 


\section{What about Anammox?}

Recent years have seen a new appreciation of the potential role of anammox, the concurrent reaction of ammonium and nitrite to form dinitrogen in anaerobic zones, in many environments. If present at the site of our study, the isotope pairing experiment ought to have revealed anammox activity through the production of ${ }^{29} \mathrm{~N}_{2}$ from labeled

${ }^{15} \mathrm{~N}$-ammonium and unlabeled nitrate or nitrite (as well as similar production from unlabeled ammonium and labeled nitrate). However, our experiments did not show an active anammox process at any depth tested. Like denitrification, this lack of chemical evidence for anammox may have been a result of our incubation method involving sediment slurries. Anammox organisms may require protected microenvironments in the aquifer that were not available in the agitated slurry incubations.

Other evidence points towards the presence of anammox-capable microbes in the STE sediments. Planctomycetes-like sequences were recovered from the 16S rRNA gene clone libraries; although they were minor a contribution. In addition, Planctomycetes-like sequences were not closely related to the known anammox organisms, and therefore the presence of these particular clones is not a strong indication of the potential for anammox processes. However, concurrent study of the recovered sediment core has revealed the presence of ladderane lipids throughout the recovered core (Saenz personal communication). Ladderane lipids are thought to be specific indicators of anammox organisms, which use the lipid to construct the anammoxosome compartment where the anammox reaction occurs. Interestingly, a second lipid crenarchaeol, specific for crenarchaeota, was shown to be closely associated with the distribution of ladderanes, 
which may indicate a relationship or shared ecology between the crenarchaeota and anammox organisms (Saenz personal communication). Kroeger and Charette (2008) have also reported the concurrent loss of ammonia and nitrate with increasing $\delta^{15} \mathrm{~N}_{\mathrm{NO}}$ in the deep salt wedge as well as the freshwater plume (on the boundary of an intruding reduced ammonia plume). However as the authors note, this concurrent loss and potential fractionation could also be the result of coupled nitrification/denitrification, or reaction with Mn-oxides on the sand grains.

The current studies show an abundant archaeal population in the surface meter and are likely the main nitrifiers in the shallow sands, however, the ecological function the deep archaea population is uncertain. Recent work in the Black Sea has shown a relationship in the abundance of archaeal amo $A$ genes (marker for crenarchaeal ammonium oxidizing organisms) and anammox specific nirS gene abundance, and linked the two processes by observing nitrification using ${ }^{15} \mathrm{~N}$-label in the suboxic zone (van Niftrik et al. 2004). Is it possible that this sort of relationship occurs in the aquifer? Are these deep archaea themselves denitrifiers? Further work must be done in this area before the significance of anammox processes in this groundwater aquifer can be assessed. This work should include molecular data, such as functional genes, or enrichment cultures that implicate specific anammox organisms and rule out mineral-pore water interactions.

\section{Implications}

The Waquoit Bay groundwater aquifer is source of nitrogen to the coastal ocean. The scale of nitrogen introduced to through this avenue is a function of the nitrogen 
loading in the watershed, the flux of water from the watershed to the coastal ocean and any transformation processes that can attenuate the dissolved nitrogen en route. Above and in the previous chapters we demonstrate geochemical signals of nitrogen removal in the upper sediments associated with groundwater denitrification coinciding with potential, archaea-mediated nitrification. Thus these aquifer sediments, especially the surface sediments, may represent an area where anthropogenic nitrogen may be ameliorated. It is hypothesized that all discharging water must transit through such a salinity zone before entering the surface waters of the bay and if these zones function similar to the surface salt zone significant nitrogen could be removed from the discharging waters.

Nitrogen transiting through the freshwater plume remains relatively unchanged over the course of the transect, due to the relatively slow rate of reactions compared to the advection rate of water. If this water were to exit into the bay in this state it would represent new nitrogen entering the bay. However, previous work has estimated that $65 \%$ of the nitrogen flux in the freshwater plume is lost over a distance of $12 \mathrm{~m}$ (14 day transit) near the CCC line, much of this was reported in mixing zones between water parcels (Kroeger and Charette 2008). At our vertical mixing between parcels appears limited, as evidenced by steep gradient especially between the freshwater plume and the deep salt wedge. However, it is reasonable, and predicted that much of the water flowing into the bay will transit through a mixing zone. We have demonstrated that mixing zones such as the upper meter can harbor populations that can transform inorganic nitrogen species at environmentally significant rates. 


\section{Future Directions}

More detailed incubation studies are needed to constrain the distribution and rate of denitrification in the aquifer sediments. The next critical study location ought to be the discharge zone. As demonstrated in the upper meter of the sediments in this study, the last centimeters or meters of transit prior to discharge may be the most active in terms of nitrogen removal from groundwater in this system. However, precious little is known about the microbiology and geochemistry of this zone other than the results presented here. Further study in this zone will yield a better understanding of how much nitrogen can be attenuated prior to discharge. A second focus for future studies is to look at the geomicrobiology in other areas of the bay. For example, how does denitrification within each water parcel east of the CCC line compare with the current study? Are the areas east of CCC line more efficient at removing nitrogen due to the presence of a less oxidized freshwater plume? Knowledge of this type may influence policy makers in prioritizing such issues such as sewer development in local communities, land use and water rights. Furthermore, detailed study of the archaeal ammonium-oxidizers, especially those presence in near the deep salt wedge could lead to a better understanding of the

plasticity of their metabolisms and their overall effect on nitrogen biogeochemical cycling in a variety of environments. 


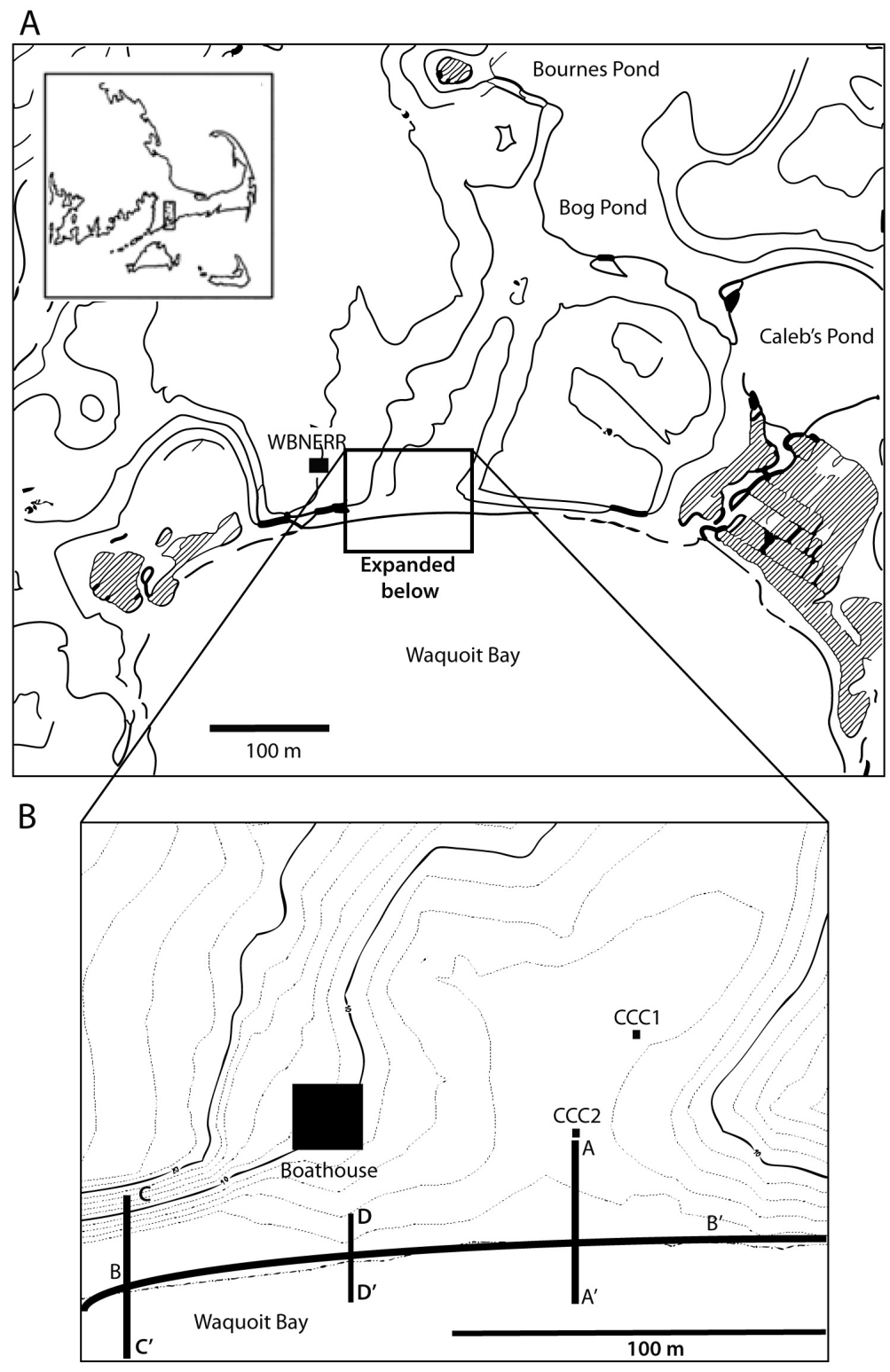

Figure 1. (A) Head of the bay, Waquoit Bay, Cape Cod, MA. Contours represent $10 \mathrm{ft}$. intervals and hatched area denotes wetlands. (B) The current and previous study location are depicted, Cape Cod Commission wells (CCC1, CCC2), transect from Charette et al. 2005, 2006 (A to A') and Kroeger et al. (2008) (A to A', B to B' and C to C'). Mulligan and Charette (2006) extended the B to B' transect east and west. 


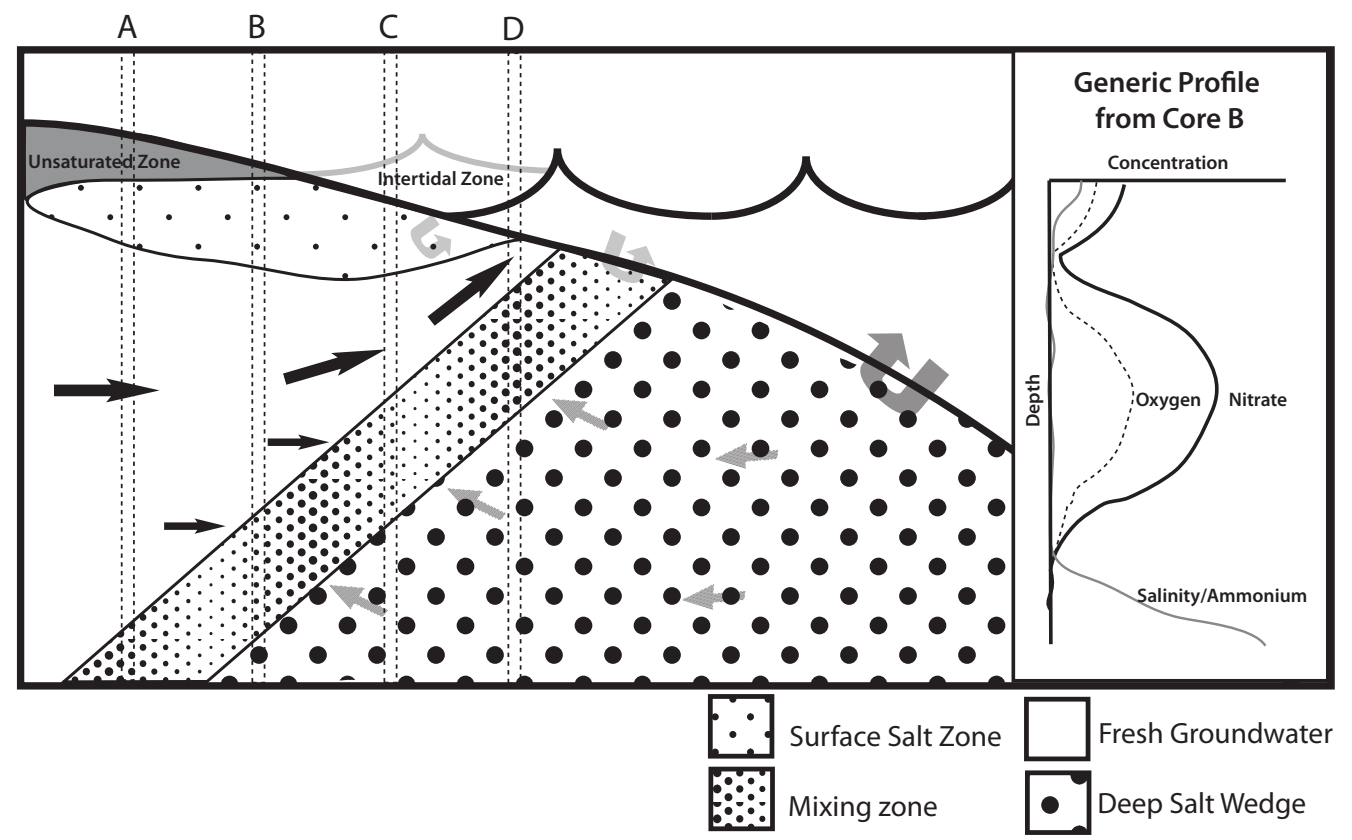

Figure 2. Schematic of SGD at Waquoit Bay. Three major water parcels are evident, a surface salt zone, a freshwater plume and a deep salt wedge. Locations A, B, C and D represent area of piezometer studies. Sediment cores were obtained from location B. 


\section{References}

Bone, S., M. Charette, C. Lamborg and M. Gonneea (2007). "Has submarine groundwater discharge been overlooked as a source of mercury to coastal waters?" Environmental Science \& Technology 41(9): 3090-3095.

Bowen, J. and I. Valiela (2001). "The ecological effects of urbanization of coastal watersheds: historical increases in nitrogen loads and eutrophication of Waquoit Bay estuaries." Canadian Journal of Fisheries and Aquatic Sciences 58(8): 14891500 .

Cambareri, T. and E. Eichner (1998). "Watershed delineation and ground water discharge to a coastal embayment." Ground Water 36(4): 626-634.

Charette, M. and E. Sholkovitz (2002). "Oxidative precipitation of groundwater-derived ferrous iron in the subterranean estuary of a coastal bay." Geophysical Research Letters 29(10): 1444.

Charette, M. A., K. O. Buesseler and J. E. Andrews (2001). "Utility of radium isotopes for evaluating the input and transport of groundwater-derived nitrogen to a Cape Cod estuary." Limnology and Oceanography 46(2): 465-470.

Charette, M. A. and E. R. Sholkovitz (2006). "Trace element cycling in a subterranean estuary: Part 2. Geochemistry of the pore water." Geochimica et Cosmochimica Acta 70(4): 811.

Charette, M. A., E. R. Sholkovitz and C. M. Hansel (2005). "Trace element cycling in a subterranean estuary: Part 1. Geochemistry of the permeable sediments." Geochimica et Cosmochimica Acta 69(8): 2095.

Cole, M. L., K. D. Kroeger, J. W. McClelland and I. Valiela (2006). "Effects of watershed land use on nitrogen concentrations and 15-nitrogen in groundwater." Biogeochemistry V77(2): 199.

Evgenidou, A. and I. Valiela (2002). "Response of Growth and Density of a Population of Geukensia demissa to Land-Derived Nitrogen Loading, in Waquoit Bay, Massachusetts." Estuarine, Coastal and Shelf Science 55(1): 125-138.

Kroeger, K., M. Cole and I. Valiela (2006). "Groundwater-transported dissolved organic nitrogen exports from coastal watersheds." Limnology and Oceanography 51(5): 2248-2261.

Kroeger, K. D. and M. A. Charette (2008). "Submarine groundwater discharge: nitrogen biogeochemistry of the discharge zone." Limnol. Oceanogr 53(3): 1025-1039.

McClelland, J. and I. Valiela (1998). "Linking nitrogen in estuarine producer to landderived sources." Limnology and Oceanography 43(4): 577-585.

McClelland, J. W., I. Valiela and R. H. Michener (1997). "Nitrogen-stable isotope signatures in estuarine food webs: A record of increasing urbanization in coastal watersheds." Limnology and Oceanography 42(5): 930-937.

Michael, H., J. Lubetsky and C. Harvey (2003). "Characterizing submarine groundwater discharge: A seepage meter study in Waquoit Bay, Massachusetts." Geophysical Research Letters 30(6): 1297.

Michael, H. A., A. E. Mulligan and C. F. Harvey (2005). "Seasonal oscillations in water exchange between aquifers and the coastal ocean." Nature 436(7054): 1145-1148. 
Mulligan, A. E. and M. Charette (2006). "Intercomparison of submarine groundwater discharge estimates from a sandy unconfined aquifer." Journal of Hydrology 327(3): 411-425.

Nielsen, L. P., P. B. Christensen, N. P. Revsbech and J. Sørensen (1990). "Denitrification and oxygen respiration in biofilms studied with a microsensor for nitrous oxide and oxygen." Microbial Ecology 19(1): 63-72.

Oldale, R. (1976). "Notes on the generalized geologic map of Cape Cod. ." U.S. Geological Survey Open-File Report 76-765.

Oldale, R. and C. O'Hara (1984). "Glaciotectonic origin of the Massachusetts coastal end moraines and a fluctuating late Wisconsinan ice margin." Geological Society of America Bulletin 95(1): 61 .

Persky, J. H. (1986). "Relation of Ground-Water Quality to Housing Density, Cape Cod, Massachusetts." Available from Books and Open File Report Section, USGS Box 25425, Denver, CO 80225. USGS Water Resources Investigations Report 864093, 1986. 28 p, 17 fig, 2 tab, 14 ref.

Sham, C. H., J. W. Brawley and M. A. Moritz (1995). "Quantifying septic nitrogen loadings to receiving waters: Waquoit Bay, Massachusetts." International Journal of Geographical Information Science 9(4): 463-473.

Spiteri, C., C. Slomp, K. Tuncay and C. Meile (2008). "Modeling biogeochemical processes in subterranean estuaries: Effect of flow dynamics and redox conditions on submarine groundwater discharge of nutrients." Water Resources Research 44(2).

Valiela, I., G. Collins, J. Kremer, K. Lajtha, M. Geist, B. Seely, J. Brawley and C. H. Sham (1997). "Nitrogen loading from coastal watersheds to receiving estuaries: New method and applications." Ecological Applications 7(2): 358-380.

Valiela, I., J. Costa, K. Foreman, J. Teal, B. Howes and D. Aubrey (1990). "Transport of groundwater-borne nutrients from watersheds and their effects on coastal waters." Biogeochemistry 10: 177-197.

Valiela, I., K. Foreman, M. LaMontagne, D. Hersh, J. Costa, P. Peckol, B. DeMeoAndreson, C. D'Avanzo, M. Babione, C.-H. Sham, J. Brawley and K. Lajtha (1992). "Couplings of watersheds and coastal waters: Sources and consequences of nutrient enrichment in Waquoit Bay, Massachusetts." Estuaries 15(4): 443-457.

Valiela, I., M. Geist, M. McClelland and G. Tomasky (2000). "Nitrogen loading from watersheds to estuaries: Verification of the Waquoit Bay Nitrogen Loading Model." Biogeochemistry 49(3): 277.

van Niftrik, L., J. Fuerst, J. Damste, J. Kuenen, M. Jetten and M. Strous (2004). "The anammoxosome: an intracytoplasmic compartment in anammox bacteria." FEMS Microbiology Letters 233(1): 7-13.

Walter, D., A. Whealan and B. Geological Survey, MA. Water Resources Div. (2004). Simulated Water Sources and Effects of Pumping on Surface and Ground Water, Sagamore and Monomoy Flow Lenses, Cape Code, Massachusetts, United States Geological Survey. 